\title{
Athens Journal of Humanities \& Arts
}

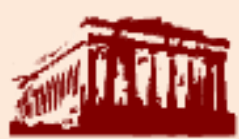

Quarterly Academic Periodical,

Volume 8, Issue 4, October 2021

URL: https://www.athensjournals.gr/ajha

Email: journals@atiner.gr

e-ISSN: 2241-7915 DOI: 10.30958/ajha

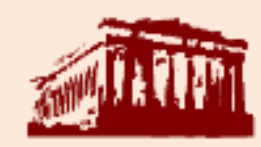

$\underline{\text { Front Pages }}$

MARIJA LIUDVIKA DRAZDAUSKIENE

An Idea of Higher Education Renewal

VIRGINIA A. G. MEIRELLES

Approaching Social Setting when Analyzing Language Change in the Early Republic

ELISA VON MINNIGERODE

"Because No One Can Seize me from Behind": Sir Christopher Hatton's Double Portrait and Elizabethan Textual Paintings

CARLA ROSSETTI

The Photo-Text in the Mussolini Era 


\section{Athens Journal of Humanities \& Arts}

Published by the Athens Institute for Education and Research (ATINER)

\section{$\underline{\text { Editors }}$}

- Dr. Stephen Andrew Arbury, Head, Arts \& Culture Unit, ATINER, Professor of Art History \& Director of the RU Art Museum, Radford University, USA.

Editorial \& Reviewers' Board

https://www.athensjournals.gr/ajha/eb

Administration of the Journal

1. Vice President of Publications: Dr Zoe Boutsioli

2. General Managing Editor of all ATINER's Publications: Ms. Afrodete Papanikou

3. ICT Managing Editor of all ATINER's Publications: Mr. Kostas Spyropoulos

4. Managing Editor of this Journal: Dr. Aleksandra Tryniecka ( $\underline{\text { bio }})$

ATINER is an Athens-based World Association of Academics and Researchers based in Athens. ATINER is an independent and non-profit Association with a Mission to become a forum where Academics and Researchers from all over the world can meet in Athens, exchange ideas on their research and discuss future developments in their disciplines, as well as engage with professionals from other fields. Athens was chosen because of its long history of academic gatherings, which go back thousands of years to Plato's Academy and Aristotle's Lyceum. Both these historic places are within walking distance from ATINER's downtown offices. Since antiquity, Athens was an open city. In the words of Pericles, Athens"...is open to the world, we never expel a foreigner from learning or seeing". ("Pericles' Funeral Oration", in Thucydides, The History of the Peloponnesian War). It is ATINER's mission to revive the glory of Ancient Athens by inviting the World Academic Community to the city, to learn from each other in an environment of freedom and respect for other people's opinions and beliefs. After all, the free expression of one's opinion formed the basis for the development of democracy, and Athens was its cradle. As it turned out, the Golden Age of Athens was in fact, the Golden Age of the Western Civilization. Education and (Re)searching for the 'truth' are the pillars of any free (democratic) society. This is the reason why Education and Research are the two core words in ATINER's name.

$* * * * * * * * * * * * * * * * * * * * * * * * * * * * * * * * * * * * * * * * * * * * * * * * * * * * * * * * * * * * * * * * * * * * * * * * * * * * * * * * * * * * * * * * * * * * * * * * * *$

The Athens Journal of Humanities \& Arts (AJHA) is an Open Access quarterly doubleblind peer reviewed journal and considers papers all areas of arts and humanities, including papers on history, philosophy, linguistics, language, literature, visual and performing arts. Many of the in this journal have been presented at the various conferences sponsored by the Arts, Humanities and Education Division of the Athens Institute for Education and Research (ATINER). All papers are subject to ATINER's Publication Ethical Policy and Statement. 
The Athens Journal of Humanities \& Arts ISSN NUMBER: 2241-7702 - DOI: 10.30958/ajha

Volume 8, Issue 4, October 2021

Download the entire issue ( $\underline{\mathrm{PDF}})$

Front Pages

An Idea of Higher Education Renewal

Marija Liudvika Drazdauskiene

Approaching Social Setting when Analyzing Language

Change in the Early Republic

Virginia A. G. Meirelles

"Because No One Can Seize me from Behind": Sir

Christopher Hatton's Double Portrait and Elizabethan Textual Paintings

Elisa von Minnigerode

The Photo-Text in the Mussolini Era

Carla Rossetti 


\title{
Athens Journal of Humanities \& Arts Editorial and Reviewers' Board
}

\author{
$\underline{\text { Editors }}$
}

- Dr. Stephen Andrew Arbury, Head, Arts \& Culture Research Unit, ATINER, Professor of Art History \& Director of the RU Art Museum, Radford University, USA.

\section{Editorial Board}

- Dr. Nicholas Pappas, Vice President of Academic Membership, ATINER \& Professor of History, Sam Houston University, USA.

- Dr. David Philip Wick, Director, Arts and Humanities Research Division, Athens Institute for Education and Research (ATINER) \& Professor of History, Gordon College, USA.

- Dr. Jayoung Che, Head, History Research Unit, ATINER \& Deputy Director of Research, Korean Academy of Greek Studies, South Korea.

- Mr. Benjamin Lewis, Founding Director, The Philology Institute, Wilmore, USA.

- Dr. Corinne Ness, Dean, Division of Arts and Humanities \& Associate Professor of Voice, Director of Music Theatre, Carthage College, USA.

- Dr. Tatiana Tsakiropoulou-Summers, Director, Athens Center for Classical \& Byzantine Studies (ACCBS) \& Director, UA in Greece, Summer Abroad Program, Department of Modern Languages \& Classics, The, University of Alabama, USA.

- Dr. Marié-Heleen Coetzee, Head, Drama Department, \& Chair of the Arts Cluster, University of Pretoria, South Africa.

- Dr. Victoria Tuzlukova, Head of Professional Development and Research Unit, Language Centre, Sultan Qaboos University, Sultanate of Oman.

- Dr. Ariel T. Gutierrez, Academic Member, ATINER \& Chair, Social Sciences Department and Music, Arts, Physical Education \& Health Education Dept., Angeles University Foundation-Integrated School, Philippines.

- Dr. Michael Paraskos, Academic Member, ATINER \& Provost, Cornaro Institute, Cyprus.

- Dr. Nursel Asan Baydemir, Professor, Department of Biology, Faculty of Arts and Science, University of Kirikkale, Turkey.

- Dr. Aieman Ahmad AL-OMARI, Professor - Ph.D. Higher Education Administration, Hashemite University, Faculty of Educational Sciences, Department of Educational Foundations and Administration, Jordan.

- Dr. Poonam Bala, Academic Member, ATINER \& Professor, Amity University, India.

- Dr. Mounis Bekhadra, Academic Member, ATINER \& Professor, University of Tlemcen, Algeria.

- Dr. Jean M. Borgatti, Academic Member, ATINER \& Professor, Department of Fine and Applied Arts, University of Benin, Nigeria.

- Dr. Rachana Chakraborty, Professor, University of Calcutta, India.

- Dr. B. Glenn Chandler, Professor of Music Theory and Fellow to the Effie Marie Cain Regents Chair in Fine Arts Sarah and Ernest Butler School of Music, The University of Texas at Austin, USA.

- Dr. Christine Condaris, Academic Member ATINER and Chairperson \& Professor, Department of Fine \& Performing Arts, Massachusetts College of Liberal Arts, USA.

- Dr. Michael Devine, Founder/Director, Centre for Alternative Theatre Training (CATT) \& Full Professor, Acadia University, Department of English \& Theatre, Canada.

- Dr. Yukihide Endo, Professor Emeritus in English, Department of General Education, School of Medicine, Hamamatsu University, Japan.

- Dr. Edward F. Mooney, Professor Emeritus, Syracuse University, USA.

- Dr. Galina Bakhtiarova, Academic Member, ATINER \& Professor of Spanish, Department 
of World Languages and Literature, Western Connecticut State University, USA.

- Dr. Rodrigo Gouvea, Professor of Philosophy, Federal University of São João del-Rei, Brazil.

- Dr. Hank Hehmsoth, Academic Member, ATINER \& Professor, Texas State UniversitySchool of Music, USA.

- Dr. Christine James, Academic Member, ATINER \& Professor, Valdosta State University, USA.

- Ms. Jill Journeaux, Academic Member, ATINER \& Professor of Fine Arts Education, Coventry University, UK.

- Dr. Bogdan Ataullah Kopanski, Professor, International Islamic University, Malaysia.

- Dr. Irena Kossowska, Academic Member, ATINER \& Professor of Art History, Polish Academy of Sciences, Copernicus University in Torun, Poland.

- Dr. James L. Lawton, Academic Member, ATINER \& Professor, Michigan State University, USA.

- Dr. Jennifer Logan, Professor, Occidental College, Music Department, USA.

- Dr. Margarita Lianou, Academic Member, ATINER \& Professor, University of York, UK.

- Dr. Henrique Marins de Carvalho, Academic Member, ATINER \& Professor, Federal Institute of Science, Education and Technology of Sao Paulo, Brazil.

- Dr. Nicholas Meihuizen, Professor, School of Languages, English Department, North-West University, South Africa.

- Dr. Angela M. Michelis, Philosophy and History Teacher in High School in Italy, PhD (University of Turin), National Italian Title of Professor in Moral Philosophy of II level (associated), Italy.

- Dr. Christopher Mitchell, Professor of Theatre Arts, Eastern Illinois University, USA.

- Dr. Anabela Moura, Academic Member, ATINER \& Professor, Instituto Politécnico de Viana do Castelo, Portugal.

- $\quad$ Dr. Mechthild Nagel, Professor, SUNY Cortland, USA.

- Dr. William O'Meara, Academic Member, ATINER \& Professor, Department of Philosophy and Religion, James Madison University, USA.

- Dr. Eloise Philpot, Academic Member, ATINER \& Professor of Art, Radford University, USA.

- Dr. Alexandria Pierce, Professor, Art History, Savannah College of Art and Design, USA.

- Dr. Laura Virginia Radetich, Professor of History, Faculty of Philosophy and Literature, University of Buenos Aires, Argentina.

- Dr. Giovanna Daverio Rocchi, Full Professor of Greek History, Department of Historical Studies, Faculty of Humanities, University of Milan, Italy.

- Dr. Luiz Paulo Rouanet, Academic Member, ATINER \& Professor, Department of Philosophy and Methods, Federal University of Sao Joao del-Rei, Brazil.

- Dr. Nancy Lee Ryuter, Dance Historian, Teacher, and Choreographer, \& Retired Professor of Dance, Claire Trevor School of the Arts, University of California, Irvine, USA.

- Dr. Elia Saneleuterio, Professor, University of Valencia, Spain.

- Dr. Gleisson R. Schmidt, Professor of Philosophy, Universidade Tecnológica Federal do Paraná, Brazil.

- Dr. Nicholas D. Smith, James F. Miller Professor of Humanities, Lewis and Clark College in Portland, USA.

- Mr. Marco Aurelio da Cruz Souza, Professor \& Choreographer, Regional University of Blumenau (FURB), Brasil, and PhD Candidate, Faculty of Human Kinetics (FMH), Technical University of Lisbon, Portugal.

- $\quad$ Dr. Maria Urma, Professor, University of Art "George Enescu", Romania.

- Dr. Bart Vandenabeele, Academic Member, ATINER \& Professor of Philosophy (Aesthetics \& Philosophy of Art), Ghent University, Belgium.

- Maja Vukadinović, Professor, Higher School of Professional Business Studies, Serbia.

- $\quad$ Dr. Suoqiang Yang, Academic Member, ATINER \& Professor, Chinese Calligraphy 
Department, Director, Institute for Interdisciplinary Research of Calligraphy Art and Information Technology, Xi' anjiaotong University, China.

- Dr. Panayotis Zamaros, Academic Member, ATINER \& Professor, Academic Counsellor, University IFM, Switzerland.

- Dr. John Doerksen, Vice-Provost (Academic Programs \& Students), Western University, Canada.

- Dr. Blaine Garfolo, Chair, Academic Advisory Committee for the DBA Program, Northwestern Polytechnic University, USA.

- Dr. Catie Mihalopoulos, Visiting Professor, Department of Enviroment, California State Polytechnic University, Pomona, USA.

- Dr. Marius-Mircea Crisan, Associate Professor, West University of Timisoara, Romania.

- Dr. Emanuela Ilie, Associate Professor, Faculty of Letters, Alexandru Ioan Cuza University of Iaşi, Romania.

- Dr. Eglè Jaškūnienė, Associate Professor \& Vice-Dean for Science, Faculty of Creative Industries, Vilnius Gediminas Technical University, Lithuania.

- Dr. Nicoleta Calina, Associate Professor, University of Craiova, Romania.

- Dr. Aldo Dinucci, Associate Professor, Federal University of Sergipe, Brazil.

- Dr. Fatma Çelik Kayapinar, Associate Professor, School of Physical Education and Sport, Mehmet Akif Ersoy University, Turkey.

- Dr. Soubhik Chakraborty, Associate Professor, Department of Applied Mathematics, Birla Institute of Technology, India.

- Dr. Caterina Pizanias, Academic Member, ATINER \& Instructor, University of Calgary, Canada.

- Dr. Mariana Cojoc, Academic Member, ATINER \& Associate Professor, Faculty of History \& Political Sciences, Ovidius University, Romania.

- Dr. Sarah L. Cole, Academic Member, ATINER \& Associate Professor, Framingham State University, USA.

- Ms. Jenefer Davies, Associate Professor of Dance, Director of the Dance Program, Washington and Lee University, USA.

- Dr. Christopher Dreisbach, Associate Professor, Johns Hopkins University, USA.

- Dr. Michael Eisman, Academic Member, ATINER \& Associate Professor, Temple University, USA.

- Dr. John Freeman, Academic Member, ATINER, Associate Professor \& Head of Theatre, Falmouth University, UK.

- Dr. Rebecca Gillan, Associate Professor, (RT) Baton Rouge Community College, USA.

- Dr. Ensiye Baqeri, Academic Member, ATINER \& Faculty Member and Assistant Professor, Encyclopedia Islamica Foundation, Iran.

- Dr. Ahmed Ghanem Hafez, Associate Professor, University of Alexandria, Egypt.

- Dr. Sophia Gilmson, Associate Professor of Piano Pedagogy, The University of Texas at Austin, USA.

- Dr.Christian Göbel, Associate Professor of Philosophy, Assumption College, Worcester, USA \&Research Associate, The Von Hügel Institute, St. Edmund's College, University of Cambridge, UK.

- Dr. Ebru Gokdag, Academic Member, ATINER \& Associate Professor, Performing Arts Dept., Anadolu University, Turkey.

- Dr. Samar Mostafa Kamal, Associate Professor, Tourist Guidance Department, Faculty of Tourism \& Hotels, Minia University, Egypt.

- Dr. Yuemin Hou, Academic MEmber, ATINER \& Associate Professor, Institute of Design Engineering, Department of Mechanical Engineering, Tsinghua University, China.

- Dr. Michele Kahn, Associate Professor of Multicultural Education, Studies in Language and Culture, University of Houston-Clear Lake, USA.

- Dr. Douglas J. King, Associate Professor, Gannon University, Department of English, USA. 
- Dr. Simonetta Milli Konewko, Academic Member, ATINER \& Associate Professor, Department of French, Italian, and Comparative Literature, University of Wisconsin Milwaukee, USA.

- Dr. Ana Ktona, Academic Member, ATINER \& Associate Professor, Tirana University, Albania.

- Dr. James Latten, Academic Member, ATINER \& Professor of Music \& Director of Instrumental Music, Juniata College, USA.

- Dr. Gina Marie Lewis, Associate Professor, Art Coordinator, Studio Art, Department of Fine and Performing Arts, Bowie State University USA.

- Dr. Maureen O'Brien, Academic Member, ATINER \& Associate Professor, St. Cloud State University, USA.

- Dr. Margo Apostolos, Academic Member, ATINER, Associate Professor, USC Kaufman School of Dance, \& Co-Director, Cedars-Sinai, USC Glorya Kaufman Dance Medicine Center, University of Southern California, USA.

- Dr. Laura Osterweis, Academic Member, ATINER \& Associate Professor, Communication Arts Department, Framingham State University, USA.

- Dr. Sayyed Rahim Moosavinia, Associate Professor, Shahid Chamran University of Ahvaz, Iran.

- Dr. Georgeta Rata, Associate Professor, B.U.A.S.V.M. Timisoara, Romania.

- Dr. Barbara Sicherl Kafol, Associate Professor of Music Didactis \& Chair of Music, Faculty of Education, University of Ljubljana, Slovenia.

- Dr. Emily Shu-Hui Tsai, Academic Member, ATINER \& Associate Professor, National Chung Hsing University, Taiwan.

- Dr. Nisha Bala Tyagi, Associate Professor, Delhi University, India.

- Dr. Laura Wayth, Associate Professor of Theatre, School of Theatre and Dance, San Francisco State University, USA.

- Dr. Sander Wilkens, Academic Member, ATINER \& Associate Profesor, Berlin University of Technology, Germany.

- $\quad$ Dr. Baruch Whitehead, Academic Member, ATINER \& Associate Professor, Ithaca College School of Music, USA.

- Dr. RajyaShree Yadav, Associate Professor, Goverment R.D. Girls College, India.

- Dr. Barbara Botter, Academic Member, ATINER \& Adjunct Professor, Federal University of Espírito Santo (UFES) - Vitória, Brazil.

- Dr. Fatima Susana Mota Roboredo Amante, Invited Adjunct- Professor, Higher School of Education of Viseu, Portugal.

- Dr. Damian Islas, Invited Profesor, University of Toronto, Canada.

- Dr. Athena Rebecca Axiomakaros, Assistant Professor, Art History, State University of New York - Nassau Community College, USA.

- Dr. Ewa Bobrowska, Academic Member, ATINER \& Assistant Professor of Philosophy and Arts, Academy of Fine Arts in Warsaw, Poland.

- Dr. Tugba Celik, Academic Member, ATINER \& Assistant Professor, Nigde University, Turkey

- Dr. Kathleen Downs, Academic Member, ATINER \& Assistant Professor of Theatre \& Drama, American University of Kuwait, Kuwait.

- Dr. Chrysoula Gitsoulis, Academic Member, ATINER \& Adjunct Assistant Professor, City College, City University of New York, USA.

- Dr. Sinem Elkatip Hatipoğlu, Assistant Professor, Department of Philosophy, Istanbul Sehir University, Turkey.

- Ms. Alma Hoffmann, Academic Member, ATINER \& Assistant Professor, University of South Alabama, USA.

- Dr. Michael James Matthis, Professor \& Director of Philosophy Dept. of English \& Modern Languages, Lamar University, USA. 
- Dr. Vassiliki Kotini, Academic Member, ATINER \& Assistant Professor, Zayed University, UAE.

- Dr. Jamshid Malekpour, Academic Member, ATINER \& Assistant Professor, College of Arts and Sciences, Department of Mass Communications, Gulf University for Science and Technology, Kuwait.

- Dr. Lejla Music, Academic Member, ATINER \& Assistant Professor, Faculty of Political Sciences, University of Sarajevo, Bosnia and Herzegovina.

- $\quad$ Dr. Esra Cagri Mutlu, Academic Member, ATINER \& Assistant Professor, Yuzuncu Yil University. Turkey.

- Dr. Sri Ram Pandeya, Assistant Professor, Ramjas College, University of Delhi, India.

- Dr. Anne Peterson, Assistant Professor, University of Utah, USA.

- Dr. Hany Sallam, Academic Member, ATINER \& Assistant Professor, Theater Department, Faculty of Arts, Alexandria University, \& General Director, National Center for Theater, Ministry of Culture, Cairo, Egypt.

- Dr. Mahdi Shafieyan, Assistant Professor of English Literature \& Islamic Hermeneutics, Imam Sadiq University, Tehran, Iran.

- Dr. Abbasuddin Tapadar, Academic Member, ATINER \& Assistant Professor, Department of English, University of Delhi, India.

- Dr. Mostafa Younesie, Assistant Professor, Tarbiat Modares University, Iran.

- Dr. Deborah S. Nash, Full-Time Philosophy Teacher, Marquette University, USA.

- Mr. Nick Higgett, Principal Lecturer, Digital Design \& Programme Leader, MA Digital Design, De Montfort University, Leicester, UK.

- Dr. Bianca Predoi, Academic Member, ATINER and Architect \& Associate Lecturer, Ion Mincu University of Architecture \& Urbanism, Romania.

- Dr. Eric Francis Eshun, Senior Lecturer, Department of Communication Design, Faculty of Art, College of Art \& Built Environment, Kwame Nkrumah Unversity of Science \& Tech., Kumasi, Ghana.

- Dr. Mike Fox, Senior Lecturer, Limerick School of Art and Design, Ireland.

- $\quad$ Dr. Vasileios Adamidis, Lecturer, Nottingham Trent University, UK.

- Ms. Georgina Gregory, Academic Member, ATINER \& Lecturer, University of Central Lancashire, UK.

- Dr. Siu-lun Lee, 李兆麟, Head of Academic Activities Division \& Senior Lecturer, YaleChina Chinese Language Center, Chinese University of Hong Kong, China.

- Ms. Lillian Nave Goudas, Academic Member, ATINER \& Senior Lecturer, University College, Appalachian State University, USA.

- Dr. Angela McCarthy, Senior Lecturer in Theology, University of Notre Dame Australia, Australia.

- Dr. Joseph Naimo, Senior Lecturer, School of Philosophy and Theology, University of Notre Dame Australia, Australia.

- Dr. Ebunoluwa Olufemi Oduwole, Academic Member, ATINER \& Senior Lecturer, Department of Philosophy, Olabisi Onabanjo University, Nigeria.

- Dr. Daphne Vidanec, Senior Lecturer, Baltazar University of Applied Sciences, Croatia.

- Dr. Doaa Sayed Abdel Azim, Lecturer of English Literature, Faculty of Languages, October University for Modern Sciences and Arts (MSA), Cairo, Egypt.

- Dr. Tsarina Doyle, Academic Member, ATINER \& Lecturer, National University of IrelandGalway, Ireland.

- Dr. Michail Mersinis, Lecturer of Fine Art Photography, the Glasgow School of Art, UK.

- Dr. Orel Beilinson, Academic Member, ATINER \& Lecturer, Harari College Worldwide, USA.

- Dr. Jonas Ciurlionis, Lecturer, Vilniaus University, Lithuania.

- Dr. Nursilah, Lecturer, Department of Dance, Universitas Negeri Jakarta, Indonesia

- Dr. Oseni Taiwo Afisi, Academic Member, ATINER \& Lecturer, Department of Philosophy, 
Faculty of Arts, Lagos State University, Nigeria.

- Dr. Edeh Peter Daniel, Lecturer 1, Department of Philosophy, University of Abuja, Nigeria.

- Dr. Ogunbiyi Olatunde Oyewole, Lecturer, Department of Religions, University of Ilorin, Nigeria.

- Dr. Declan Patrick, Lecturer, Liverpool Hope University, UK.

- Dr. Nur Silah, Lecturer, Dance Department, Negeri Jakarta University, Indonesia.Dr. Stephen Steinberg, Lecturer, University of Pensylavia, USA.

- Dr. Ensa Touray, Academic Member, ATINER \& Lecturer, University of the Gambia, Gambia.

- Dr. Margherita Dore, Adjunct Lecturer in English (Translation Studies), Department of European, American and Intercultural Studies, University of Rome "La Sapienza", Italy.

- Dr. Eleni Tracada, Academic Member, ATINER \& University Principal Tutor in Built Environment, Faculty of Art, Design \& Technology, College of Engineering \& Technology, University of Derby, U.K.

- Dr. Yakup Mohd Rafee, Coordinator, Fine Arts Program, Faculty of Applied and Creative Arts, University Malaysia Sarawak (UNIMAS), Malaysia.

- Dr. Tanja Tolar, Senior Teaching Fellow, School of Oriental and African Studies (SOAS), London, UK.

- Dr. Susana Furphy, Honorary Research Fellow, The University of Queensland, Australia.

- Dr. Alessandra Melas, Postdoctoral Research Fellow, Department of History, Human Sciences and Education, University of Sassari, Italy.

- Dr. Douglas Lucas Kivoi, Researcher/Policy Analyst, the Kenya Institute for Public Policy and Research Analysis (KIPPRA), Kenya.

- Dr. Margot Neger, Academic Member, ATINER \& Postdoctoral Researcher, University of Salzburg, Austria.

- Dr. Sabitha.S.R.Najeeb, M.Phil, Ph.D., University of Dammam, Kingdom of Saudi Arabia.

- Dr. Nasrin Daftarchi, Ph.D. of French Literature, Iran.

- Mr. Sanjit Chakraborty, Research Scholar, Department of Philosophy, Jadavpur University, Kolkata, India.

- Dr. Pritika Nehra, Academic Member, ATINER \& Ph.D Research Scholar, Department of Humanities\& Social Sciences, Indian Institute of Technology, India.

- Mr. Richard Finn, Academic Member, ATINER \& Program Director, Stage and Screen Arts, Whitireia NZ, New Zealand.Dr. Arunima Roychoudhuri, Research Scholar, University of Kalyani, India.

- Dr. Christina Papagiannouli, Academic Member, ATINER \& Research Assistant, Faculty of Creative Industries, University of South Wales, UK.

- Dr. Rossana Raviola, Department of Humanities, Philosophy Section, University of Pavia, Italy.

- Mr. Hugh O'Gorman, Director, Athens Center for Theatre Studies (ACTS) \& Professor and Head of Performance, California State University, Long Beach, USA.

- Ms. Viviana Soler, Academic Member, ATINER \& Research Professional, National Research Council (CONICET) \& Sur National University (UNS), Argentina.

- Ms. Subha Marimuthu, Academic Member, ATINER \& Research Scholar, Bharathi Women's College, India

- Ms. Arunima Roychoudhuri, Academic Member, ATINER \& Full Time Research Scholar, University of Kalyani, India.

- Dr. Inma Garín, University of Valencia, Spain.

- Dr. Manoranjan Mallick, Academic Member, ATINER \& Lecturer, Post-Graduate Department of Philosophy, Utkal University, India.

- Dr. Christina Banalopoulou, PhD Student, University of Maryland, USA.

- Dr. Julijana Zhabeva-Papazova, Academic Member, ATINER \& Musicologist/Independent Scholar, FYROM. 
- Dr. Pablo Villavicencio, PhD in Communication and Semiotics, University PUC-SP (Pontifícia Universidade Católica de São Paulo), Brazil.Mr Mathodi Freddie Motsamayi, $\mathrm{PhD}$ Candidate/Researcher, Centre for Visual Art, University of KwaZulu-Natal, South Africa.

- Mrs. Danielle K. Garrison, MFA Dance Candidate-Aerial Dance Track, University of Colorado-Boulder, Aerialist, Dancer, Choreographer and Teacher, Artistic Director and Founder/DKG Dance, Director of the Student Company and Performer/Frequent Flyers Productions, Inc., Teaching Artist/Colorado Ballet, USA.

- Ms Sandra Philip, Academic Member, ATINER, PhD Candidate \& Associate Lecturer, Edge Hill University, UK.

- Ms. Christine Staudinger, Academic Member, ATINER \& PhD Candidate, University of Vienna, Austria.

- Ms. Raluca-Eugenia Iliou, Academic Member, ATINER \& Doctoral Research Fellow, Brunel University, UK.

- Mrs. Aleksandra Tryniecka, PhD Student, Maria Curie-Skłodowska University, Poland \& Research Fellow, ATINER, Greece.

- $\quad$ Ms. Stephanie Rennick, Teaching Assistant, University of Glasgow, UK.

- Mrs. Tiffany Pounds-Williams, Academic Member, ATINER \& Tufts University, USA.

- Mr. Mark Konewko, Academic Member, ATINER \& Director of Chorus, Marquette University, USA.

- General Managing Editor of all ATINER's Publications: Ms. Afrodete Papanikou

- ICT Managing Editor of all ATINER's Publications: Mr. Kostas Spyropoulos

- Managing Editor of this Journal: Dr. Aleksandra Tryniecka (bio)

\section{Reviewers' Board}

Click Here 


\section{President's Message}

All ATINER's publications including its e-journals are open access without any costs (submission, processing, publishing, open access paid by authors, open access paid by readers etc.) and is independent of presentations at any of the many small events (conferences, symposiums, forums, colloquiums, courses, roundtable discussions) organized by ATINER throughout the year and entail significant costs of participating. The intellectual property rights of the submitting papers remain with the author. Before you submit, please make sure your paper meets the basic academic standards, which includes proper English. Some articles will be selected from the numerous papers that have been presented at the various annual international academic conferences organized by the different divisions and units of the Athens Institute for Education and Research. The plethora of papers presented every year will enable the editorial board of each journal to select the best, and in so doing produce a top-quality academic journal. In addition to papers presented, ATINER will encourage the independent submission of papers to be evaluated for publication.

The current issue is the fourth of the eighth volume of the Athens Journal of Humanities \& Arts (AJHA), published by the Arts, Humanities and Education Division of ATINER.

Gregory T. Papanikos

President

ATINER 


\section{Athens Institute for Education and Research}

\section{A World Association of Academics and Researchers}

\section{$13^{\text {th }}$ Annual International Conference on Visual and Performing Arts 6-9 June 2022, Athens, Greece}

The Arts \& Culture Unit of ATINER is organizing its $13^{\text {th }}$ Annual International Conference on Visual and Performing Arts, 6-9 June 2022, Athens, Greece sponsored by the Athens Journal of Humanities \& Arts. The aim of the conference is to bring together academics and researchers of visual and performing arts, and other related disciplines. You may participate as stream leader, presenter of one paper, chair of a session or observer. Please submit a proposal using the form available (https:/ / www.atiner.gr/2022/FORM-ART.doc).

\section{Academic Members Responsible for the Conference}

- Dr. Stephen Andrew Arbury, Head, Arts \& Culture Unit, ATINER and Professor of Art History, Radford University, USA.

\section{Important Dates}

- Abstract Submission: 8 November 2021

- Acceptance of Abstract: 4 Weeks after Submission

- Submission of Paper: 9 May 2022

\section{Social and Educational Program}

The Social Program Emphasizes the Educational Aspect of the Academic Meetings of Atiner.

- Greek Night Entertainment (This is the official dinner of the conference)

- Athens Sightseeing: Old and New-An Educational Urban Walk

- Social Dinner

- Mycenae Visit

- Exploration of the Aegean Islands

- Delphi Visit

- Ancient Corinth and Cape Sounion

\section{Conference Fees}

Conference fees vary from $400 €$ to $2000 €$

Details can be found at: https://www.atiner.gr/2021fees 


\section{Athens Institute for Education and Research}

A World Association of Academics and Researchers

\section{$7^{\text {th }}$ Annual International Symposium on Religion \& Theology \\ 23-26 May 2022, Athens, Greece}

The Humanities \& Education Division of ATINER is organizing its $7^{\text {th }}$ Annual International Symposium on Religion \& Theology, 23-26 May 2022, Athens, Greece. The aim of the conference is to bring together academics and researchers of Religion, Theology and other related disciplines. You may participate as stream leader, presenter of one paper, chair of a session or observer. Please submit a proposal using the form available (https:/ / www.atiner.gr/2022/FORM-REL.doc).

\section{Important Dates}

- Abstract Submission: 25 October 2021

- Acceptance of Abstract: 4 Weeks after Submission

- Submission of Paper: 25 April 2022

\section{Academic Member Responsible for the Conference}

- Dr. William O'Meara, Academic Member, ATINER \& Professor, Department of Philosophy and Religion, James Madison University, USA.

\section{Social and Educational Program}

The Social Program Emphasizes the Educational Aspect of the Academic Meetings of Atiner.

- Greek Night Entertainment (This is the official dinner of the conference)

- Athens Sightseeing: Old and New-An Educational Urban Walk

- Social Dinner

- Mycenae Visit

- Exploration of the Aegean Islands

- Delphi Visit

- Ancient Corinth and Cape Sounion

More information can be found here: https://www.atiner.gr/social-program

\section{Conference Fees}

Conference fees vary from $400 €$ to $2000 €$

Details can be found at: https://www.atiner.gr/fees 


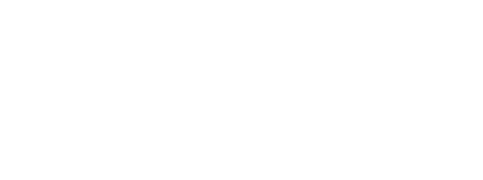




\title{
An Idea of Higher Education Renewal
}

\author{
By Marija Liudvika Drazdauskiene*
}

\begin{abstract}
Beginning with the briefest reference to the state of higher education today, this paper overviews moral and philosophical concepts of and disposition to education in ancient Greece from the works of Plato and Aristotle, takes a summary view of the subjects taught, sums up the subject content of liberal arts and the principles of rhetoric. The author assumes that even if a dedicated return to the classical ideals may never happen in higher education today, a few concrete ideas might be helpful. With reference to concrete works of classical authors, a suggestion is made to stop never-ending reforms in universities, to recover the teaching of such subjects as style in language and literature programmes, to renew the subjects of history, philosophy and logic and to introduce memory-based learning while paying tribute to classical antiquity and regaining local traditions.
\end{abstract}

\section{Introduction: The Problem and the Approach}

The problem of present-day higher education and why it has to be discussed is the loss of inherited, time-tested orientation through the unprecedented growth of knowledge in and information from sciences, through the extension of mass media and popular culture, through the inflation of knowledge in "the overinformed world" in which professionals lack the certainty and trust in themselves to take responsibilities. The loss of orientation is due to insufficient respect for professors in authority and to the fallen ethical, moral and academic standards.

This paper is of a potential renewal of higher education, not of innovation or reform. The idea is to suggest a direction of focus to what had been accepted in education but came to be ignored in the long run or was lost in present-day reforms and to what may be borrowed from the ideas of classical antiquity, which always retained its genuine insight and irreplaceable authenticity. The word 'renewal' has been borrowed from the James G. Martin Center for Academic Renewal (https://www.jamesgmartincenter/).

Although there was no higher education of the present-day model in classical antiquity, a number of conceptions and caveats known in classical antiquity are applicable today. Some of the precepts of classical antiquity have been retained, although impoverished, in present-day higher education.

Modern higher education has certain features, sometimes acknowledged only formally, which were treated as values in classical antiquity. For instance, in The Laws, Plato defined upbringing as that (activity which) leads a citizen to

"Professor, Wszechnica Polska, Poland. 
becoming virtuous and obliges him to desire to become more virtuous, to perfect himself, to live, to rule and to subject himself to the law ${ }^{1}$. Some of these features are formally acknowledged in present-day education and distorted while putting too great an emphasis on freedom without any regard to responsibilities in small countries of new democracies.

\section{The Principal Classical Concepts of Education}

According to Plato, education is required for the educated to be able to decide for themselves rather than to resort to strangers in decision making and "to let them be your masters and judges" 2 This concept is based on a true idea of freedom.

Aristotle assumed that education of youth should be foreseen and regulated by the law, should be one for all and should be executed under the law. Aristotle further posited that, "depending on the singular goal of the state, education should be one and obligatory to all. It should not be private when everyone teaches privately whatever he chooses"3.

Present-day higher education is regulated by the law in numerous countries, yet this bears little semblance to the classical concept because of corporate, lobbyist and social interference rather than genuine support.

Aristotle mentions discussions of the content of education, i.e discussions about what should be taught. There was no agreement on this then ${ }^{4}$. This

1. "Plato, The Laws," (trans.) A. Kudulyte-Kairiene, in Dilyte, 1991, 96.

2. "Does it not seem to you a scandalous thing, and a strong proof of defective education, to be obliged to import justice from others, in the character of lords and judges, in consequence of the scanty supply at home? Nothing can be more scandalous" (Plato, The Republic, Book III, 405ff).

3. "And just as there must also be preparatory training for all skills and capacities, ..., it is obvious that there must also be training for the activities of virtue. But since there is but one aim for the entire state, it follows that education must be one and the same for all, and that the responsibility for it must be a public one, not the private affair which it now is each man looking after his own children and teaching them privately whatever private curriculum he thinks they ought to study. In matters that belong to the public, training for them must be the public's concern" (Aristotle, The Politics, Book VIII. i, 1337a11-1337a32). "It is clear that there should be law laid down about education, and that education itself must be made a public concern" (Aristotle, The Politics, Book VIII. ii, 1337a33).

4. "But we must not forget the question of what that education is to be, and how one ought to be educated. For in modern times there are opposing views about the tasks to be set, for there are no generally accepted assumptions about what the young should learn, either for virtue or for the best life; nor yet is it clear whether their 
question in classical antiquity concerned the subjects in the sense that classical authors deliberated on whether the required subjects were to be those which "develop thinking skills or the character of the soul", those that were useful in daily life or those that led to abstract knowledge ${ }^{5}$. Aristotle himself suggested a fair solution: "It is doubtless that useful things should be taught" .

But Aristotle further mentioned that there is education which is required for sons not because it is useful in practical life and so necessary but "because it suits a free man and is beautiful in itself"7.

The discussion continues today and leads to an extreme emphasis on practical things (such as technical execution in manual work or commercial subjects in the humanities at university). The question remains whether this solution is an optimal issue. Without indicating direct cause and consequence relations, classical antiquity had an unarguable position on this. As society divided into free men and slaves, Aristotle thought that "the young should be taught those things that would not turn them into amateur performers and craftsmen. The amateur's activity was such an engagement, craft or learning which precluded the use of the mind, body and soul the way that is required of a free man, in his virtuous work and engagement"8. Amateur engagements were

education ought to be conducted with more concern for the intellect than for the character of the soul" (Aristotle, The Politics, Book VIII. ii, 1337a33).

5. "The problem has been complicated by the education we see actually given; and it is by no means certain whether training should be directed at things useful in life, or at those conducive to virtue, or at exceptional accomplishments. (...) And there is no agreement as to what in fact does tend towards virtue. For a start, men do not all prize the same virtue, so naturally they differ also about the training for it" (Aristotle, The Politics, Book VIII, ii, 1337a33).

6. "Then as to useful things: there are obviously certain essentials which the young must learn; but it is clear (a) that they must not learn all useful tasks, since we distinguish those that are proper for a free man and those that are not, and (b) that they must take part only in those useful occupations which will not turn the participant into a mechanic" (Aristotle, The Politics, Book VIII. ii, 1337b4). "It is also clear that there are some useful things, too, in which the young must be educated, not only because they are useful (for example they must learn reading and writing), but also because they are often a means to learning yet further subjects" (Aristotle, The Politics, Book VIII, iii, 1338a17).

7. Aristotle, The Politics, Book VIII, ii.

8. "We must reckon a task or skill or study as mechanical if it renders the body or intellect of free men unserviceable for the uses and activities of virtue. We therefore call mechanical those skills which have a deleterious effect on the body's condition, and all work that is paid for. For these make the mind preoccupied (without leisure), and unable to rise above lowly things. Even in some branches of knowledge worthy of free men, while there is a point up to which it does not demean a free man to go in for them, too great a concentration on them, too much mastering of detail - this is liable to lead to the same damaging effects that we have been speaking of. In this connection 
those which diminish the body and make the mind and soul unfit for virtuous work. Base engagements were those which money buys ${ }^{9}$. This seems too nice to be neglected today, if only we could aspire to such heights.

It may be assumed, to illustrate, that crafts or DIY activities encouraged today would have been amateur activities for Aristotle, whereas services, which were paid slaves' work, would have been base engagement for a free man in classical antiquity. There are worse cases which may illustrate the point of engagements of the present-day. To commit a young talented girl to multiply printed texts in a foreign language by a mechanical typewriter without instructing her first in the basic knowledge of that foreign language is committing the person to an amateur activity for a miserable pay. To subject a highly educated woman to unemployment because she rejected advances and, later, to deny the person academic titles and to abuse her grandchildren for her rejection of the advances and harassment at a pre-retirement age are base activities. There are more examples of base activities, "which money buys" today, and the most obvious would be plagiarism and the supply of students' degree papers for a payment (online and in person). The negative evaluation of classified work in antiquity indicates how distanced the concepts of humanitarian values and morality have been between then and now.

Classical authors recommended to select the best schools and the best teachers for the young and the best works to be used in school. Classical antiquity had the concept of "a decent man" and had it uppermost in their mind whether they wrote about teachers, orators or philosophers. The initial schooling had to be based on the best selected works of literature and attended by the best teachers as the beginning was the most important for "a young tender being": it is at the beginning that the features which may be desirable to burgeon in the young take $\operatorname{root}^{10}$

Never letting ethic and morality slip from their mind, authors of classical antiquity highlighted gratitude as a treasure: "the gratitude of a decent man for a kind turn is a real treasure". Amid the precepts to respect wealth, but only moderately, Isocratus reasoned that it is worthy to aspire to the best while being content with what one has ${ }^{11}$.

Aristotle further posited that there is a limit to which man remains free in his engagements and learning. Too deep and too meticulous engagement and

the purpose for which the action or the study is undertaken makes a big difference" (Aristotle, The Politics, Book VIII, ii, 1337b4).

9. See footnote 8 .

10. "Then are you aware, that in every work the beginning is the most important part, especially in dealing with anything young and tender? For that is the time when every impression, which one may desire to communicate, is most readily stamped and taken" (Plato, The Republic, Book II, 377).

11. Isocratis Orationes: ПPO $\Sigma$ HMONIKON, I.27-29. 
research were not considered good as such engagements tended to the slave's work. Plinius Secundus also noted of the assumption that it is not required to read much; it is rather required to read diligently ${ }^{12}$.

These and other similar precepts have not gone unnoticed. In his excellent practical study, Style, a British classicist, F. L. Lucas, gave his judgment on and recommendation of what is required of education, which is to know the best ${ }^{13}$.

Today, we have a similar aspiration in the name of creativity included in the $21^{\text {st }}$ century skills, among which creativity features significantly. However, the background and foundations differ in the concept of a creative man. As has been mentioned, apart from the concept of a free man, classical authors questioned how much the subjects taught contribute to the development of the soul or intellect, which is gone today. We think we know more of intellect, body and economy, but the character of the soul has slipped from our thinking and philosophical bias has gone out of all reasoning.

In the question of the subjects taught, classical authors referred to their essential conception of education: education "should add up to what may be lacking from birth (nature)"14. In early education, imitation, listening to stories and observing lessons initially should feature at the start. Imitation should follow only the virtuous and the best examples. Plato demanded that stories for children had the required harmony. Hence was the requirement of the classics to select what works should be used in education and what should not, as first impressions were the most powerful ${ }^{15}$. A child had to be directed to virtue from tender years and had to develop a desire to perfect oneself ${ }^{16}$. This principle

12. Pliny, Fifty Letters of Pliny. Second Edition. (Selected and ed.) A. N. SherwinWhite (Oxford, New York: Oxford University Press), Letter 36 (VII.9).

13. "... what matters at school, at the University, and in after-life is not new interpretations of Shakespeare - they are usually false; not new theories of criticism they are usually futile; but a knowledge of the best that has been said or written, and the power - I admit the limited extent to which this can be taught - to speak and write." (F. L. Lucas, 1955, 25-26).

14. "For those who divide life into periods of seven years are not far wrong and we ought to keep to the division that nature makes. For all skill and education aim at filling the gaps that nature leaves" (Aristotle, The Politics, Book VII, xvii).

15. See footnote 10, above. Cf.: "He (Theodorus, the tragic actor) never allowed any other actor, even quite an inferior one, to appear on the stage before him because, he said, an audience always takes kindly to the first voice that meets their ears. The same thing is true of men's relations both with each other and the things they encounter: we always delight more in what comes first" (Aristotle, The Politics, Book VII, xvii).

16. "But if there is any possibility of persuading them, that to quarrel with one's fellow is a sin of which no member of a state was ever guilty, such ought rather to be the language held to our children from the first, by old men and old women, and all elderly persons, and such is the strain in which our poets must be compelled to write. $/ \ldots / \ldots$, we ought to esteem it of the greatest importance that the fictions which 
excluded and forbade immoral pictures and stories. The argument was: "If bad speech is forbidden, so should be inappropriate views and performances"17.

The fights and wrangling of Gods even in Homer were not a becoming literature for the young. It took an adult man to learn of Gods' escapades ${ }^{18}$. Plato's decision on poets was quite rigorous: Plato suggested that the representation of Gods had to follow certain rules: (1) it was required that the poets represented Gods as they are, whether in epic, lyric or tragedy, because "nothing that is good is hurtful". Further reasoning led to the assumption, that, "being good, God couldn't be the cause of everything and was not guilty of many things, as good was scarcer than evil"19. The reason of good is definitely God and the reasons of evil are to be sought elsewhere" 20 . The second rule in the representation of Gods by the Poets stated that the Poets should not fantasise about Gods and scare the children. It was required not to treat Gods like magicians who change their shapes, "go about by night in the likeness of strangers from every land", scare and "foster timidity in their children". Gods do not change their shapes and do not deceive us either by word or action ${ }^{21}$. Disobedient poets were not suitable as children's literature and were to be "ousted from the state". Plato suggested that poetry, even that of Homer, could be expunged. Such lines which blacken Hades and magnify horrors are "neither true nor beneficial to men who are intended to be warlike" 22 . Some praise, it was believed, would be more useful ${ }^{23}$.

children first hear should be adapted in the most perfect manner to the promotions of virtue" (Plato, The Republic, Book II, 378).

17. "The legislator ought to banish utterly from the state, as he would any other evil, all unseemly talk; for the unseemly talk lightly dropped results in conduct of a like kind. Especially, therefore, must it be kept away from youth: let them not hear or see anything of that kind" (Aristotle, The Politics, Book VII, xvii, 1336b3).

18. "And since we exclude all unseemly talk, we must also forbid gazing at debased paintings or stories. Let it therefore be a duty of the rulers to see that there shall be nothing at all, statue or painting, that is a representation of unseemly actions, except in the shrines of certain gods (Notably Dionysus) whose province is such that the law does actually permit scurrility. The law further allows men who have reached the appropriate age to pay honour to these gods on behalf of their wives, their children and themselves" (Aristotle, The Politics, Book VII, xvii).

19. "If that be so, then God, in as much as he is good, cannot be the cause of all things, according to the common doctrine. On the contrary, he is the author of only a small part of human affairs; of the larger part he is not the author: for our evil things far outnumber our good things: and the good things we must ascribe to no other than God, while we must seek elsewhere, and not in him, the causes of the evil things" (Plato, The Republic, Book II, 379).

20. Plato, The Republic, Book II, 379.

21. Ibid, 381

22. Plato, The Republic. Book III, 387.

23. "These verses, and all that are like them, we shall entreat Homer and the other poets not to be angry if we erase, not because they are unpoetical, so much the 
"The upbringing which aims at gaining money, influence or other deceitful, senseless and wrong activity" was not "worthy of the name of education"24. Aristotle weighed in saying that it was least becoming to free people and people of magnanimous spirit to look for profit in everything ${ }^{25}$. Plato specified further saying that "future expectations meant hope, the expectation of suffering bred fear and that of pleasure courage". Reason ruled above all these and decided what was better and what was worse. Further, "reason, which is the common precept of the state", becomes the law, in Plato's understanding ${ }^{26}$. Referring to Pericles in Socrates's name, Xenophon thought that "laws is everything what has been decided by the collective meeting of the people and put down, and which determine what may be done and what may not" 27 . More specifically, Pericles was said to have claimed that "the law is what the government of the state decides and fixes in writing on what is obligatory" 28 . Classical authors aspired to beauty and moderation, sought law and order. This was important as they tended to base education, as mentioned earlier, moral and immoral behaviour, on law. As we hear from the President of ATINER, the classical dicta of moderation, law and beauty are the living rules in Greece today. It is mainly because of that that this presentation has been prepared for this particular Conference, in Greece and I gratefully acknowledge the invitation.

As we understand it today, we do not deny the rule of reason in the state organization of education, its administration, curriculae and in teaching, but trust in authority and therefore respect for reason are gone. We have many speakers, no authorities and no respect for authority, whatever their reason and intention. We no longer aspire to, absolutely, the best. There has even been a Guardian publication online in which, guided by a fixed premise, André Spicer (2019) argued that excellence and being outstanding are overrated and that being good enough, whether in schools, health service and in other spheres, is perfectly sufficient ${ }^{29}$.

less ought they to be recited in the hearing of boys and men, whom we require to be freemen, fearing slavery more than death" (Plato, The Republic, Book III, 387).

24. Plato, The Laws, I.643-644.

25. "',' some useful things /.../ are often the means to learning yet further subjects. Similarly they must learn drawing, not for the sake of avoiding mistakes /.../ but rather because it teaches one to be observant of physical beauty. But to be constantly asking 'What is the use of it?' is unbecoming to those of broad vision ('magnanimous') and unworthy of free men" (Aristotle, The Politics, Book VIII, iii, 1338a37).

26. Plato, The Laws, I.643-644.

27. Xenophon, The Memories of Socrates, I.2.

28. Ibid.

29. André Spicer, Excellence is Overrated. Let's Embrace being Good Enough Instead (The Guardian, 2019). 


\section{Highlights of Primary Education in Classical Heritage}

Classical authors have left a very definite description of the initial or primary education. Upbringing should be executed through fine arts and gymnastics, as they "train body and soul" ${ }^{30}$. A man who manages both these subjects for the good of his soul may be considered to have a perfect achievement and to be an excellent creator of harmony ${ }^{31}$. The focus on good for the soul drawn from education was not a formal point in classical antiquity. It was a belief. Plato has extensive deliberation on the essence and being of the soul in his different works ${ }^{32}$, and this has special meaning in his concept of education. In Phaedrus ${ }^{33}$, Plato elaborates on the immortality of the soul, which it owes to its ceaseless movement ${ }^{34}$. The power of the soul is magnified owing to its wings in Plato's concept. Wings are there to lift up the soul to what is divine, beautiful, wise and good. Because of this attachment to the good, wings separate the soul from what is low and miserable ${ }^{35}$. The soul can be compared to a winged two-horse chariot and its driver. It is the soul who moves the chariot but the two horses in the soul's power are different: one is a good horse of commendable heritage, while the second is its opposite and the charioteer's work is hard and exhausting.

The winged soul itself flies in the skies and issues its influence over the world. But if it loses its wings, it whirls around until it hits upon something hard, settles in the thing and identifies with its earthly body, which, moved by the soul, seems to be moving on its own. This unity was given the name of a mortal. The immortal, on the contrary, has body and soul etternally bound together. It is only we, imperfect in our thinking, who represent God as some immortal entity of body and soul ${ }^{36}$.

The loss of the wings is a major cause of transformations in the soul for Plato, as is the upbringing of the soul in education ${ }^{37}$. Arguing about the influence of a lover, who is usually subjugating, faithless and envious, Plato gives preference to the indifferent other and warns of the unbecoming education of the soul, which is

30. Plato, The Republic, Book III, 411.

31. "Then whosoever can best blend gymnastic with music and bring both to bear on the mind most judiciously, such a man we shall justly call perfect in music, and a master of true harmony, much rather than the artist who tunes the strings of the lyre" (Plato. The Republic, Book III, 412).

32 Plato, The Great Dialogues of Plato (trans.) W. H. D. Rouse (ed.) Eric H. Warmington and Philip Rouse (New York: A Mentor Book from New American Library, 1956).

33. Plato, Faidras (trans.) Naglis Kardelis (Vilnius: Aidai, 1996).

34. Ibid, 245b-d.

35. Ibid, 246c-d.

36. Ibid, 246b-c.

37. Ibid, 241b-d. 
the highest virtue in itself ${ }^{38}$. The soul has to feed on the best of choices. That is why, the young have to be taught only select subjects by the best teachers, read selected works, avoid the ugly and unbecoming. It has to be stressed in this context again that the emphasis on the good for the soul as a divine entity in education was an integral part of belief rather than that of a method to Plato. Importantly, the good of the soul extended further to the decency and honour of a free man in classical antiquity.

\section{Highlights of Schooling in Classical Heritage}

Concerning subjects, arithmetic and geometry were found very useful and were taught as obligatory to the persons "who are destined to take part in the weightiest affairs of state" ${ }^{\prime 39}$, while liberal arts and gymnastics were equally fitting to men and women, although their physical strength could differ ${ }^{40}$. Alluding to the knowledge of the efficiency of a Sarmatian woman, Plato claimed that "men and women should be trained in equal measure" because "the state diminishes if men and women are separated in training" 41 "No free man should learn any science like a slave" because "compulsory knowledge is weak"42. Education should cultivate reason which is to search further, "instead of trusting the senses, which provide nothing for certainty"43.

It was customary, wrote Aristotle, to teach grammar, gymnastics, music and drawing to young children. Aristotle considered music to be the beginning of everything ${ }^{44}$ and the art which creates pleasant leisure. Plato argued similarly of music but criticised poetry and the poets quite rigorously. The age of schooling divided thus: up to 5 years of age, a child had to be taught at home. From 5 to 7 years, he had to observe lessons of the subjects he was to learn later. From 7 to 21, education was secondary and deficiencies of nature attended to, "For all skill and education aim at filling the gaps that nature leaves" 45 . Alongside, the same

38. Ibid, 241b-c-d.

39. Plato, The Republic, Book VII, 525ff.

40. Ibid, Book V, 482.

41. Plato, The Laws, XII.

42. "Arithmetic, therefore, and geometry, ... to pave the way for dialectic, must be taught our pupils in their childhood; - care being taken to convey instruction in such a shape as not to make it compulsory upon them to learn. /.../ Because, I replied, no trace of slavery ought to mix with the studies of the freeborn man. For the constrained performance of bodily labours does, it is true, exert no evil influence upon the body; but in the case of the mind, no study, pursued under compulsion, remains rooted in the memory" (Plato, The Republic, Book VII, 536.

43. Plato, The Republic, Book VII, vii.

44. Aristotle, The Politics, Book VIII, ii.

45. Ibid, Book VII, xvii. 
authors posited that children should be taught through games, but only in tender age. Teenagers were not to have a leisurely $\operatorname{life}^{46}$. Later, Seneca (1991) hinted at life-long learning while emphasising that the young have to learn the most ${ }^{47}$. Xenophon characterised his friends and man who is worthy of respect: it is "he who knows what is required to know and can express it in words" 48 . This dicta features in an inherited definition of good education to this day.

\section{Insights into Higher Education Drawn from Classical Heritage}

The subjects singled out by Plato, (gymnastics, grammar, arithmetic, geometry and astronomy), and by Aristotle, (grammar, rhetoric and dialectic/ logic, music and painting), and mentioned above developed later into septem artes liberales, which were studied by senior young men. Septem artes liberales later $\left(5^{\text {th }}\right.$ $6^{\text {th }}$ century AD) divided into trivium (grammar, rhetoric and dialectic) and quadrivium (music, arithmetic, geometry and astronomy), which were studied in Medieval universities ${ }^{49}$. The concept of liberal arts has been retained to this day and, with slight modifications, they have been in the programmes of some present-day higher schools, such as the Vilnius College even at the end of the twentieth century. The higher level of education in classical Greece was theology ${ }^{50}$. Greece also developed the theory of rhetoric while minding that a well-speaking man always made a good impression.

In his dialogue, Phaedrus, Plato (1996) outlined requirements to a good speech which had to be like a human being, with head, body and limbs, which meant the beginning, development and end ${ }^{51}$. A good speech had to be moderate in length and language. Referring to the opinion of the best orators of his time, such as Pericles, Thaesias, Gorgias, Trasymachos, Lysias and others, Plato put forward the opinion of Socrates that a speech had to be of a uniform composition, moderate in length and subtle, as it was a mixed use of language.

Classical antiquity developed and Aristotle wrote about three kinds of rhetoric: legal rhetoric, advisory or political rhetoric and rhetoric of display or ceremonial speeches which received the least attention ${ }^{52}$. The approach in legal

46. Ibid, Book VIII, v, 1339a26.

47. Seneca, The letters of Morality to Lucillius (trans.) D. Dilyte. In Dilyte, Dalia, 166175. 1991.

48. Xenophon, Memories of Socrates, I.2.

49. Henrikas Zabulis, The Rhetoric of Classical Antiquity. A Course of Lectures MS (Vilnius: Vilnius University, 1995).

50. Zabulis, The Aesthetics of Classical Antiquity. A Course of Lectures MS (Vilnius: Vilnius University, 1995).

51. Plato, Faidras (trans.) Naglis Kardelis (Vilnius: Aidai, 1996).

52. Aristotle, Rhetoric, Book I. 
speeches could be through the content of the case or through the law. The orator's purpose changed accordingly: the orator could divulge, delight or move. The material in legal rhetoric had to be worked out in three stages: accumulation, presentation of the argument and oral presentation which included stylistic polish and presentation. Consequently, a speech had to have two-four parts (introduction, which could be cut, the material, the argument and conclusion) in Aristotle's conception, which gradually became three parts (introduction, development and conclusion). In his work, Rhetoric, Aristotle ${ }^{53}$ focused considerably on the theory of proof. Keeping the orator in mind, Aristotle singled out artistic and common proof (pistes atechnoi and pistes etechnoi), while the success of persuasion depended on the speaker's personal character, on the audience's disposition and on persuasive arguments in the speech ${ }^{54}$. To create the audience's favourable dispositon, the focus was kept on an introduction. In the development of a speech, the focus turned to proof. The followers of Aristotle extended the two kinds of proof defined by Aristotle, into ethical, emotional and logical proof ${ }^{55}$. Aristotle required that proof were based on three premises: the general opinion, opinion derived from evidence and that drawn from examples. He found two kinds of examples, actual facts and examples devised by the speaker, which could be fictitious.

Plato, Aristotle and, later, Quintillianus emphasised the orator's decency above all. Quintillianus made an especially strong point of orator's decency as he believed that anything could be proven with the help of words ${ }^{56}$.

Rome had a similar initial education: primary where pupils learned writing, grammar, secondary and the orator's level, which is sometimes compared with the present-day higher education ${ }^{57}$. According to Plato, Aristotle and Quintillianus, the orator had to seek extensive knowledge, as the object of rhetoric was all fields of which a speech may be required. It was not only liberal arts and subjects such as diction, convincing presentation, the ability to use tropes and figures, but also geometry and philosophy that would educate the orator. Although the Romans took over much of the rhetorical heritage of classical Greece, Cicero was the outstanding orator and author in Rome. Cicero rejected counter statements in proof and singled out five parts of a speech: introduction (proemiun), narrative (narratio), position statements (proration), proof (probatio) and rejection (refutatio). Aristotle mentioned repeatedly that he was speaking about the content of a speech, while artistic presentation of a speech mattered to Cicero,

53. Aristotle, Rhetoric. Poetics (trans.) N. Rhys Roberts and Ingram Bywater (New York: The Modern Library, 1954).

54. Ibid, ii, 4-21.

55. Zabulis, The Rhetoric of Classical Antiquity. A Course of Lectures MS, 1995.

56. Ibid; Quintillianus, "The Education of Orator."

57. Dalia Dilyte, The Pedagogues of Antiquity. Compiled by Dalia Dilyte (Kaunas: “Sviesa", 1991). 
who introduced elocution, which meant a trained voice and exemplary articulation, as a fifth part of a speech ${ }^{58}$.

Cicero mentioned the physic of a good orator and a possibility to improve it by knowledge and training, yet warned that physical deficiencies cannot be overcome ${ }^{59}$. Cicero was sensitive to criticism of the audience, to recognition and how it could be won through training ${ }^{60}$. It was known to Cicero that all orators, even the major, feel tremor before they make a speech in public and that this is the strongest in good orators. This was not to discourage young people from studies of rhetoric, it was rather to show the ways. Cicero mentioned a confident speaker as opposed to the fearful to say that it was not too much confidence that was a virtue. If an orator could not say anything valuable to give credit to his name and win the audience's approval, he was dishonest and even his nervous disposition in making a speech could not improve his merit ${ }^{61}$.

Cicero wrote about the duty of an orator to speak convincingly, to analyse his theme with respect to its credibility, about different modes of proof in legal, advisory and ceremonial speeches and about five stages of work on a speech: the selection of a topic, its development depending on circumstances and the argument, verbal expression and polish, committing to memory and delivery ${ }^{62}$. He wrote specifically of the selection of words and composition, rhythm and metre in presentation, and the use of the voice ${ }^{63}$.

In Book II of De oratore (Cicero in Dilyte, 1991), Cicero analysed how legal speeches should be worked out depending on whether the question was general or contentious, whether the question could be treated as general or particular. Cicero acknowledged Greek orators and philosophers, especially Socrates and Aristotle $^{64}$. He emphasized that effort was essential in the training of an orator. Science could only orientate the person in training, while effort and virtue were the most important together with an insight into the richness of philosophers' language, which they developed with resort to their knowledge and verbal wealth bypassing concrete rules ${ }^{65}$. This shows one extra time that virtue, talent and decency were prized above all by classical authors, which indicates the role of work and effort as the essence of studies.

58. Zabulis, The Rhetoric of Classical Antiquity. A Course of Lectures MS, 1995.

59. Cicero, De Oratore, Book I, 25.

60. Ibid, 29.

61. Ibid, 25.

62. Ibid, 31 .

63. Ibid, 33.

64. Ibid, Book II, 38.

65. Ibid, 35. 


\section{Traditional Legacy of East European Universities}

As is obvious to the informed, the subjects in the education of children and the composition of a speech following the rules of rhetoric of classical Greece and Rome have been in the programmes of virtually all schools and universities of Western tradition to this day. Kinds of rhetoric, oratory, where it still exists, the composition of a speech and, further, the composition of any essay have been taught following the principles defined by the classical authors and philosophers mentioned above. The principles are valuable and subsequent communication by those who master the art is excellent in whatever genre of speech.

In 1995, concluding his course on aesthetics of classical antiquity, an experienced classical professor in the University of Vilnius, evaluated the education of classical antiquity by saying the following: "There is everything here, you see. It is possible to take the classical model of education and apply it in schools." Although the person held a government post and was in the position to move toward an application of the classical model of education in present-day schools, he never made a step in that direction. What has been said indicates why: it is not only that the content has changed considerably in education. It is also, and most importantly, the founding principles, especially, morality and, with it, the culture. The physical potential of man has also changed, as well as his experience, and with it, the very concepts. What God, the soul, morality and moderation mean to a Greek, a classical scholar and to a common man in Eastern Europe today, are very different things. A return to classical ideas, which can well be called ideals, may take a long way or never happen. However, it is known how education and, especially, higher education evolved in the last thirty years, following the restoration of democracy and the regaining of state independence in small East European countries.

The education that was inherited from the Soviet rule in Eastern Europe was not really broken. It had a system, was regulated by the state and had qualified professors and lecturers. If regulation, called for by Aristotle in his day, was at times extreme in Eastern Europe in the twentieth century, it ensured stability and carried along a number of positive prescriptions.

The liberation of the 1990s brought about changes in all spheres of life. Changes in education were urged most ardently by the narrow-minded and politically biased. And so, education was being reformed. Ignoring academic input and experience, systemic stability and academic achievements, reforms started, went on and have not yet finished. 


\section{Drawing on the Irreplaceable in Classical Heritage}

Withholding myself from further complaints and minding Plato's concept of the dangers of changes in the state, a reference to The Laws by Plato ${ }^{66}$ is required. In the law in question, an Athenian discusses the uses of gymnastics for the young and continues with the question of an appeal of the unusual over the usual $^{67}$.

The Athenian insists that it is important that the speaker and the listener should avoid strange and unusual things. This point takes him to the question of the state. The argument is this: it is not known in any state that the manner of games would affect the issue of laws or determine the soundness of laws in the state. A decision of the state permitting the same people to engage in the same games preserves the stability of established laws. Yet if the same games were altered and innovated by various changes because of the inclination of the young to despise the same, whether it is their bodies, dress, general opinion of the beautiful and the ugly, and to value that who is given to permanent changes, to anything new and unusual, "we would be right in assuming that nothing can be more perilous than this to the state. Such processes change delicately the habits of the young to despising the past and to adding value to novelty. There is no greater peril to the state than this like talk and thought"68. Plato's Athenian elaborates further: "If we attune the ear more sensitively to one another, we shall be aware that, except for changes in evil issues, all such changes are very dangerous" ${ }^{\prime 69}$. Skipping the Athenian's deliberation on changes of the seasons, bodies, thinking habits and the soul, it is relevant to focus on Plato's direct statement: "Laws under which people were educated for a long time, have become immovable because of some godly sight and nobody heard of them being altered. Every soul respects laws and fears damaging anything in them of what was formerly fixed"70. Plato's Athenian further assumes that changes in games initiated by the young are neither serious, nor vicious entertainments in themselves. That is why the young are not forbidden their innovations. Yet, any oversight of a possibility that, engaged in the new games, the young will grow different than the children of the previous generations, may lead to unwanted states. They will next seek a different life, different laws and different customs. Unlike some superficial changes, this will endanger the customs, their praise and blame will change quickly and the greatest caution will be required in this.

Whether influenced by their inclination to changes or by permanent changes in the state, the young in small new democracies in Eastern Europe have been

66. Plato, The Laws, IV-VI; Dilyte, 1991, 101-104.

67. Plato, The Laws, VII.

68. Ibid.

69. Ibid.

70. Ibid. 
becoming more and more unmanageable in schools. A practical piece of advice offers itself in the context of the present deliberation. First, the ugly and damaging sights and texts, against which ancient Greeks emphatically warned, have so polluted the space of the young through television, mass media and the internet that they have lost all emotive-intellectual balance, to say nothing of their sense of beauty. Second, schools no longer select works of literature, except the established classics, with diligence and dedication, for the young to read, probably because of the avalanche of published works and certainly because teachers are so overstrained and exhausted that they do not mind the processes. Selection was yet practiced by the postwar generation of teachers, but, as democratic liberties spread, so dedication declined. A very modern observation in this context would be that one of the reasons of the declining discipline in schools is learning without rules, which is most obvious in language learning. The idea would be that learning language with rules would teach the young discipline, accuracy and culture, while dismissing language rules leads to the opposite of these, to disobedience, aggression and impudence ${ }^{71}$. An attempt to alter the described conditions in school would combine at least two classical principles, those of selection and discipline, if we bear in mind Aristotle's recommendation that teenagers "should not lead an idle life" and that school should preserve discipline.

The first idea in this presentation to be put forward is to curb changes in education. If change is harmful to the state, change is perilous in education. The Nobel-winning economists warned against dangers of change in economy. Endless change in education means endless harm, especially when reforms last indefinitely long. And they do in some countries in Eastern Europe.

The second idea would concern the subjects. This talk is of a renewal of education, not innovation, so the past tradition has to be borne in mind. Thinking of the greatest achievers from the generation of the 1920s-1930s in statesmanship, oratory and education, remembering the precepts of classical antiquity to the useful subjects for the young, (gymnastics, arithmetic, geometry, and astronomy, by Plato; gymnastics, reading and writing, dialectic, music and drawing by Aristotle), it is relevant to remember the piece of advice that "it is required to teach not only the useful subjects, but also such subjects which reveal other subjects". Here belongs drawing, which, to Aristotle, could teach not only orientation among things but also give ideas of the theory of beauty. Music was very special to Aristotle, "the beginning of everything", as, apart from laborious engagement in its performance, music was known to give pleasure and to teach the delight of leisure ${ }^{72}$.

71. Marija L. Drazdauskiene, "Teaching Language for the Attainment of Culture," A Poster-Presentation at the 53rd Annual International Conference of IATEFL (Liverpool, 1 April 2019).

72. Aristotle, The Politics, Book VIII, v. 
As education in oratory in Greece and later, in Rome, could have been compared to present-day higher education, it may be reiterated that orators had to seek the widest possible knowledge because the topics of speeches are unlimited, include philosophy, specifically, dialectic, the use of tropes and figures and the training of the voice. It is known that these subjects were in the curricular of EFL and literature in the University of Vilnius in the 1960s-1970s. Most of them have remained to the present-day, yet diminished. Seeking a renewal in the field, an idea would be to retain these subjects in the study of the English language, while reviving the teaching of style, which was lost with the success of pragmatics and discourse studies. Style studies have been retained in major Universities and major authors have retained the precepts of classical rhetoric in their books ${ }^{73}$. Even the newest textbooks of English and French today include the teaching of language through poems and songs, with other accents on culture and arts. That is reminiscent of the classical selection of subjects. A renewal would also require the focus on history and philosophy in literature studies. A third idea would concern memory-based learning.

A turn to memory-based learning borrowed from classical antiquity might help resurrect at least some of the basic principles and dicta, which would influence the final achievement.

In addition to what has been mentioned as possessed in higher education, may be applicable today and what exists in an impoverished form in higher education, there are more definite ideas to be drawn from classical antiquity. If present-day education can at all be compared with education in classical antiquity, we may seek ideas of its renewal in Plato's dialogue Phaedrus (Plato, 1996). Among such themes as the soul and kinds of souls, poetic madness (human madness and godly madness), ethic, erotic and logos, and criteria of a good speech, in this dialogue, Plato has Socrates deliberating on the invention of script by the Egyptians. When addressing the Egyptian ruler Tamus, the inventor of numbers, geometry, astronomy, the game of draughts and the dice as well as script, claimed that "writing will make the Egyptians wiser and of better memory, as script was a medicine for wisdom and memory" ${ }^{\prime 74}$. Socrates had a very straight and plain observation on this. In the words of the ruler of Egypt, Socrates replied: "An inventor of script, you have shown favour to the tools. You have claimed the opposite of their power. The souls of those who learn the script will gain forgetfulness because nobody will cater for memory. They will call to memory what the script prompts, exteriorly, rather than interiorly, from themselves. You

73. Cf Peter Verdonk, Stylistics (Oxford: Oxford University Press, 2002); Edward P. J. Corbett, and J. Connor Robert, Style and Statement (Oxford, New York: Oxford University Press, 1999); Donald Davidson, American Composition and Rhetoric (New York: Charles Scribner's Sons, 1968).

74. Plato, Phaedrus, 274d-275b. 
have invented a reminder rather than a medicine for memory and put forward an opinion rather than truth to your pupils"75.

This particular argument suits the $21^{\text {st }}$ century better than an inventory of any skills. It is a great loss that present-day schooling and higher education have veered away from a resort to memory. Whatever the services of the computer, it has done a major disservice to memory and to the classical tradition in education. The analogy between Socrates's story in Plato's Phaedrus of the uses of script and the function of the computer is too obvious. The loss in schools is as distinct. Students cannot overview books and papers they suppose they had read, in their graduation papers. They simply transpose fragments of text from relevant literature to their own papers. In answer to my question, whether he read the book I had lent him, one student at the University of Vilnius in the 1980s responded saying, "I have Xeroxed, i.e. photocopied, it". I have not met many young people for a long time who would be excited about the books they are supposed to be reading, excited to discuss the ideas, to hear opinions and evaluations, to argue about them, outside university.

Memory-based learning should not identify with rote-learning, of which educators forewarn today. Like the soul in the goodness of man, memory-based learning leads to the same idea of good in man. This was so in classical antiquity because reason featured in the existence of the soul. It is only immortal souls who ascend to sublimity and it is given only to them to observe what is beyond the skies. Even the poets had no access to this realm beyond. This realm is an unpalpable entity, featureless and colourless, perceivable only to reason, which is the helmsman of the soul. The right kind of cognition attaches to the soul through reason. Like God's thoughts, the thoughts of every soul which tend to feed on good, draw on and attach themselves to the realm beyond in truth and bliss ${ }^{76}$. Reason would guide man in his other decisions. It has been mentioned above that mechanical and amateur learning was unbecoming in classical antiquity. Similarly, memory-based learning should be only taken in as much as good in man requires.

\section{Conclusions}

Without a further complaint, I can say with confidence that the classical concept of learning as the process "to acquire knowledge of or skill in something through study of experience or by being taught; to commit to memory" 77 has gone out of fashion. Some dictionaries omit the sense of 'committing to memory'

75. Ibid.

76. Plato, Phaedrus, 247c-d-e; Plato, Faidras, 1996.

77. Concise Oxford English Dictionary, Twelfth Edition (ed.) Angus Stevenson and Maurice Waite. (Oxford: Oxford University Press, 2011), 811. 
from the definition of this concept altogether. There are, therefore, changes in the quality of knowledge and in the knowledge that earlier generations had had. The retiring postwar generation of teachers is the last one to have the sense of knowledge as power and knowledge as pleasure. What a pilot could do from memory with no technology assisting him in the 1940s, a language and literature student today can never do an analogous task with resort only to his memory. Whatever the grievances of the humanities, learning has gone out of fashion and, with it, the learned. Some grievances are there because the loss of humanitarian ideals may be beyond repair and because commercial levers in education go unchallenged. Through mistrust of the knowing and neglect of authority, we may also have admitted some unwanted developments ourselves, which turned to grievances in the end. Authority and trust have been damaged on two sides: on the side of society where "everyone knows everything" and on the side of personal deterioration in achievement in learning.

A late classical author, Seneca, to remember, questioned the virtues of the teaching of liberal arts and found none. Seneca stated that liberal arts do not teach morality or purity of the soul by themselves. The manner of learning in the humanities today only demonstrates that liberal arts, altered today, yet integrated in the education system, did not preclude the degradation. Only those in presentday humanities who achieve the highest proficiency esteem the subjects and the people. So, a turn to memory-based learning might be prospective and perhaps productive, if the liberal young in new democracies were attuned not only to liberties but also to responsibilities, so that discipline in schools were not treated as a violation of human rights and a task to learn as psychological pressure. In higher education, a salvation from change, the renewal of several subjects mentioned above and at least some emphasis on memory-based learning could improve the much-deplored state of the humanities today.

To be accepted, this idea about a renewal in higher education and about the three suggestions, (of a termination of reforms, a renewal of the teaching of such subjects as philosophy and logic, the history and theory of literature and style, and an introduction of memory-based learning), would require a wider publicity and discussion in teaching communities, while integrating the subjects into the curricula, the consent of the financing bodies might be required and negotiations between Deans and Heads of departments. Ongoing variations in the subjects taught would permit a replacement of such subjects as technical editing or technical translation by the subject of literature or style. If universities had given up the teaching of philosophy, logic and the history of literature altogether, the introduction of these subjects would require considerable adjustments, but could be done at the expense of sex education, gender equality or contemporary politics and similar subjects because philosophy and history might give these their minimum due of their own.

To be introduced, memory-based learning would have to be discussed and defined in the concept of classical antiquity and introduced in syllabuses by 
individual teachers. The formal task would be quite simple: it would mean assigning a certain percent (for instance, 20\%) of a subject matter for memorization. This should not be mechanical nor be seen as a scholastic measure. It has been becoming a custom initiated by the British Council in the teaching of English to expect of a teacher that he or she summarise his lessons and his courses in a couple/a few statements. It might be remembered that the best professors practiced this in the 1960s, while learning Latin sententiae by heart as part of an examination task has remained the age-old practice in some universities to this day. If such summaries as mentioned above are memorised, they might be sufficient for a lesson. Additionally, select definitions and laws would have to be committed to memory in their contexts in certain subjects. But most importantly, undergraduate students would have to be encouraged to discuss what they read for their graduation or term papers with their lecturers to be able to remember what they had read and to understand where the knowledge belongs in their own reasoning. This, inevitably, would increase the stress on the lecturer, but students still have planned classes for graduation projects, which some of them attend and some of them miss. Classes of this kind would profit from a turn to discussion of the reading matter and no special changes would be required. Viewing the state of the art rationally, the suggested changes would not appear radical. Their principles had been integrated in the programmes of many universities, so that a fresh focus would really mean only a renewal to both lecturers and administrators, while the students would, hopefully, accept a word of wisdom.

\section{Bibliography}

Aristotle. Rhetoric. Poetics. Translated by N. Rhys Roberts and Ingram Bywater. New York: The Modern Library, 1954.

Aristotle. The Politics. Translated by T. A. Sinclair. Revised and Re-Presented by Trevor S. Saunders. London: The Penguin Group, 1981.

Cicero. "De Oratore." [By Oratore.] Translated by E. Ulcinaite. In Dalia Dilyte, 139-161. 1991.

Concise Oxford English Dictionary. Twelfth Edition. Edited by Angus Stevenson and Maurice Waite. Oxford: Oxford University Press, 2011.

Corbett, Edward P. J. and Robert J. Connor. Style and Statement. Oxford, New York: Oxford University Press, 1999.

Davidson, Donald. American Composition and Rhetoric. New York: Charles Scribner's Sons, 1968.

Dilyte, Dalia. The Pedagogues of Antiquity. Compiled by Dalia Dilyte. Kaunas: "Sviesa", 1991.

Dilyte, Dalia. “The Major Teachers of Antiquity and their Theories." In Dalia Dilyte, 7-26. 1991. 
Drazdauskiene, Marija L. “Teaching Language for the Attainment of Culture.” A PosterPresentation at the 53 ${ }^{\text {rd }}$ Annual International Conference of IATEFL. Liverpool, 1 April 2019.

Isocratis. Isocratis Orationes: ПРО $\triangle H M O N I K O N$, I.27-29. Lipsiae Sumptibus et Typis B. G. Teubneri. MDCCCLXIV.

Lucas, F. L. Style. London: Cassell, 1955.

Plato. The Republic of Plato. Translated by John Llewelyn Davies, M. A. and David James Vaughan, M. A. London: Macmillan and Co, 1927.

Plato. The Great Dialogues of Plato. Translated by W. H. D. Rouse. Edited by Eric H. Warmington and Philip Rouse. New York: A Mentor Book from New American Library, 1956.

Plato. Faidras. Translated from the Greek by Naglis Kardelis. Vilnius: Aidai, 1996.

Plato. "The Laws." Translated into Lithuanian by A. Kudulyte-Kairiene. In Dalia Dilyte, 95118. 1991.

Pliny. Fifty Letters of Pliny. Second Edition. Selected and Edited by A. N. Sherwin-White. Letter 36 (VII.9). Oxford, New York: Oxford University Press, 1987.

Quintillianus. "The Education of Orator." Translated into Lithuanian by A. Velickiene. In Dalia Dilyte, 176-234. 1991.

Seneca. The letters of Morality to Lucillius. Translated by D. Dilyte. In Dilyte, Dalia, 166175. 1991.

Spicer, André. Excellence is Overrated. Let's Embrace being Good Enough Instead. The Guardian, 2019.

Verdonk, Peter. Stylistics. Oxford: Oxford University Press, 2002.

Xenophon. "Memories of Socrates." Translated by Vanda Kazanskiene. In Dalia Dilyte, 3661. 1991.

Zabulis, Henrikas. The Aesthetics of Classical Antiquity. A Course of Lectures MS. Vilnius: Vilnius University, 1995.

Zabulis, Henrikas. The Rhetoric of Classical Antiquity. A Course of Lectures MS. Vilnius: Vilnius University, 1995. 


\title{
Approaching Social Setting when Analyzing Language Change in the Early Republic
}

\author{
By Virginia A. G. Meirelles*
}

\begin{abstract}
Any study that concentrates on language change should assess factors such as historical context and social structure. ${ }^{1}$ However, approaching the phonetic and phonological changes that took place during the Early American Republic (1776-1861) is a complex task since it was a period of considerable social, political and economic reorganization ${ }^{2}$ Additionally, although many biographies and studies on selected issues have been written, the scholarship about the period remains unconnected and fragmented. ${ }^{3}$ As such, this article exposes the theoretical and methodological preparation for a research on sound change during the Early American Republic by discussing how to undertake data collection and how to approach data analysis.
\end{abstract}

\section{Introduction}

The Early Republic (ER) was characterized by many events like the development of political parties, the hostility between those parties, foreign relations issues, and the westward movement. In the half century after the Revolution, "political institutions were established" (Congress, Supreme Court) and "a political economy was worked out." ${ }^{4}$ The territorial expansion and industrialization raised considerable controversy over topics such as slavery and Native Americans. It is true that the expansion opened the country to settlers who were looking for a better life but, at the same time, it displaced the Native Americans and triggered the debate over whether slavery should be allowed in the new territories or states. Additionally, the Industrial Revolution transformed North America into an industrialized nation with a capitalistic economy that in turn affected the social structure and generated disagreements connected to the perpetuation of slavery. Indeed, because of the dramatic socio-economic changes

*Professor, University of Brasília, Brazil.

1. P. Trudgill and R. Watts, Alternative Histories of English (London/NY: Routledge, 2002); M. Laing, "Multidimensionality: Time, Space and Stratigraphy in Historical Dialectology," in M. Dossena and R. Lass (eds.), Methods and Data in English Historical Dialectology (Germany: Peter Lang, 2004), 49-96.

2. C. Clark, "Comment on the Symposium on Class in the Early Republic," Journal of the Early Republic 25, no. 3 (2005): 559.

3. E. Pessen, "Social Structure and Politics in American History," The American Historical Review 87, no. 5 (1982): 1290-1325; G. S. Wood, "The Significance of the Early Republic." Journal of the Early Republic 8, no. 1 (1988): 1-20.

4. Ibid, 1. 
and technological advances, the United States (U.S.) emerged as a very different nation from the colony that had declared independence. ${ }^{5}$

In terms of the linguistic situation, while some records indicate that during the early 1800s, the Englishmen did not tell American and British varieties apart, ${ }^{6}$ others reveal that the English were aware of the peculiarities of the American variety. ${ }^{7}$ Likewise, some reports mention that in the 18th and early 19th centuries, the English in America was uniform ${ }^{8}$ but others show that by 1780 residents in the South and North were conscious of speech differences. ${ }^{9}$ The disparity of the reports may be explained because settlers brought American English from different parts of the British Isles at different times. As a consequence, it is possible that different combinations of dialects were present in different proportions in different areas and were evaluated differently by Englishmen. However, that dialect mixture situation did not last more than a generation or two when people living in the same location leveled out the original dialects, giving rise to koinézation. ${ }^{10}$ As a result, in the early years of settlement, dialect differences were established on the east coast as each community adopted a dialect that was 'mixed' with respect to its origins, but uniform in its current characteristics throughout the community. ${ }^{11}$

At the same time, since national identification and language awareness are interconnected $^{12}$ and since American nationalism emerged after the Revolution, ${ }^{13}$

5. J. T. Lemon and G.B. Nash, "The Distribution of Wealth in Eighteenth-Century America: A Century of Change in Chester County, Pennsylvania, 1693-1802," Journal of Social History 2, no. 1 (1968): 1-24; E. Pessen, "Social Structure and Politics in American History," 1982; G. S. Wood, "The Significance of the Early Republic," 1988; M. Zakim, "The Business Clerk as Social Revolutionary; or, a Labor History of the Non-Producing Classes," Journal of the Early Republic 26, no. 4 (2006): 563-603.

6. J. Fisher, "British and American, Continuity and Divergence," in J. Algeo (ed.), The Cambridge History of the English Language (Cambridge University Press, 2001), 73.

7. J. L. Dillard, Perspectives on American English (The Hague: Mouton, 1980), 3; A. W. Read, "British Recognition of American Speech in the Eighteenth Century," in J. L. Dillard (ed.), Perspectives on American English (The Hague: Mouton, 1980), 15-35.

8. T. Twining, Travels in America 100 Years Ago: Being Notes and Reminiscences (New York: Harper and Brothers, Publishers, 1894); J. L. Dillard, Perspectives on American English, 1980, 20-22.

9. M. Montgomery, "The Crucial Century for English in the American South," in M. D. Picone, C. E. Davies (eds.), New Perspectives on Language Variety in the South: Historical and Contemporary Approaches (Tuscaloosa, Alabama: The University of Alabama Press, 2015).

10. P. Trudgill, Sociolinguistics: An Introduction to Language and Society (London: Penguin, 2000), 157.

11. Ibid.

12. E. Haugen, "Dialect, Language, Nation," American Anthropologist 68: (1966): 922935.

13. G. S. Wood, “The Significance of the Early Republic,” 1988, 1. 
it is expected that the formative period of the American variety might have started after the Revolutionary War. In fact, according to Montgomery, ${ }^{14}$ the emergence of a Standard American English goes back to one or two generations before the Civil War (1861-1865) with the formation of regional and social variations simultaneously, ${ }^{15}$ a situation that must have been influenced by the intense internal migration that was taking place at the period.

Because both linguistic and social factors affect language change, studies of the diffusion of language change need to consider social aspects. To examine how social and economic events may have influenced the diffusion of changes, this article describes the relevant historical events of the ER by summarizing, in sequence, the economic, demographic and cultural changes that took place during the period. Special attention is given to the changes in class structure because social barriers may halt the diffusion of linguistic features. Demographic and migratory details are included because they may provide valuable information to access linguistic diffusion, at the time that reports on the level of literacy of men and women may help decide on the kind of documents that should be examined. As such, the objective of this article is to consider the relevant historical events and the socio-economic conditions of the ER and propose an approach to the examination of written documents that will create a corpus that is representative of the period. The article examines, first, the historical events, the demographic conditions, the social structure, the economic changes and the level of literacy at the time. After that, it discusses the influence those aspects may have had on the diffusion of language change. Lastly, it proposes a methodology for collecting data for a research study that analyses language change in the ER.

\section{Literature Review}

\section{Historical Events}

The Second Continental Congress issued the Declaration of Independence in 1776 and in 1789, the Articles of Confederation (adopted in 1777) were replaced by the Constitution of the United States of America which created a new independent nation. The same year, George Washington was elected first president.

During the first years after the Declaration of Independence, there were no political parties. However, factions started to form around dominant personalities which later gave birth to two parties. The Federalist Party (Alexander Hamilton) had the support of merchants and financiers throughout the country, favored

14. M. Montgomery, "The Crucial Century for English in the American South," 2015, 99.

15. M. Montgomery, "The History of American English," in D. R. Preston (ed.), Needed Research in American Dialects (N.C.: Duke University Press, 2004), 1. 
Britain in its battles with France and vehemently defended a strong Federal constitution. The Federalists dominated until 1800 when Jefferson's victory diminished their influence. On the other hand, the Republicans (Thomas Jefferson and James Madison) identified mostly with farmers who opposed the new federal taxes created by the Federalists and feared the loss of individual and state rights by a concentration of central authority with the creation of a strong federal government.

In fact, in its first years, the new country witnessed insurrections and debates over nationalism, individualism and state control. During the $1780 \mathrm{~s}$, due to the government mismanagement of economic issues, rebellions erupted, principally, in Massachusetts and Pennsylvania. Additionally, the fear of losing individual rights and the opposition of the antifederalist to the creation of a stronger federal government resulted in negotiations over the ratification of the Constitution that lasted several years. Because of that, not all the thirteen states ratified the Constitution at the same time.

American politics became more democratic in the 1820s when the requirements for voters to own property were abolished and the printed ballots were adopted. The period between 1828 and 1854 was characterized by rising levels of voter interest and high degrees of personal loyalty to parties. Two parties dominated the scene: Whigs (John Quincy Adams, Daniel Webster) who represented the wealthier planters, merchants, financiers, and professionals and wanted to modernize the society by creating a transportation infrastructure; and Jacksonians (Andrew Jackson, Stephen Douglas) who advanced expansion of farmers and planters into new lands.

At that time, the U.S. depended on maritime transport of agricultural goods. However, because of the war with Napoleon, Britain had taken a series of actions, among which was establishing a naval blockade, to impede trade between France and the U.S., and creating an allegiance with Native Americans to obstruct American expansionism and trade with Canada. The blockade intensified the growing tensions between Britain and the U.S. and finally resulted in a declaration of war in 1812. The war (1812-1815) affected the transportation of goods and, consequently, destroyed the American Economy. After the war, nationalism increased across the country, at the same time that a sense of sectionalism and individualism grew.

The Native Americans were unable to stop white settlement after the War of 1812 because they lost British support. As a consequence, in 1830, Congress passed the Indian Removal Act and in 1834, a special Indian Territory (now part of Oklahoma) was established. The Native Americans were promptly forced to move to that territory in what came to be known as the "Trail of Tears".

The territorial expansion started in 1803 with the Louisiana Purchase and continued throughout the period. In 1818, Britain agreed to settle the western border with Canada (the eastern border was settled in 1845) and in 1819, the Spanish agreed to cede Florida Territory to the U.S. Soon after, settlers began 
moving into Texas (1820) and into the Pacific Northwest (1830). Texas was annexed in 1845; Oregon became a state in 1846; and, Arizona was purchased in 1854. As a result of the territorial expansion, by 1864, the original thirteen colonies had become 36 states. Yet, since the North (anti-slave) was against the annexation of Texas and the South (pro-slave) favored it, Texas annexation was viewed as a pro-slavery initiative which eventually contributed to the Civil War.

Overall, during the ER nationalism and individualism increased, at the same time that external and internal conflicts were common. The internal disputes were marked by oppositions that were in part related to geographic location federalists/antifederalists, small farmers/wealthier planters, North/South, expansionists/anti-expansionists. In linguistic terms, the growing nationalism may have stimulated the adoption of American variants. In addition, the antagonism within the country may have prevented the spreading of changes by creating invisible barriers to the existent natural ones. For those reasons, the differences between North and South and the consequences of the territorial expansion will be examined in the next section.

\section{Demography}

The population of the U.S. that in 1700 was 250,000 inhabitants, in 1790 had reached 4 million people, and in 1861, 30 million. Yet, it was as heterogeneous as it had been since the beginning. In fact, it was only in the New England states that travelers say to have met unmixed descendants of Englishmen. ${ }^{16}$

The original thirteen colonies were grouped into three regions: the New England (or Eastern) states, the Middle states and the Southern states. The New England states (NE) were mostly settled by Pilgrims (lower class) and Puritans (middle class) who composed about 75\% of the American population in 1776. Harriott mentions that in this region the inhabitants had good manners and a love of letters.

On the other hand, the Middle states had a mixed, but predominantly European origin, ${ }^{17}$ although some Natives were also reported in urban areas. ${ }^{18}$ The population consisted mostly of manual workers or shopkeepers ${ }^{19}$ and, contrary to

16. J. Harriott, Struggles through Life (Dublin: John Exshaw, 1815), 38; J. H. St. John de Crèvecoeur, Letters from an American Farmer (London: For the Author, 1782).

17. J. Algeo, The Cambridge History of the English Language (UK: Cambridge University Press, 2001), 11.

18. J. Harriott, Struggles through Life, 1815, 39-42; J. H. St. John de Crèvecoeur, Letters from an American Farmer, 1782, 177-193; D. Ford, Journal of an Expedition Made in the Autumn of 1794 (The New York Public Library, 1794).

19. J. T. Main, The Social Structure of Revolutionary America (Princeton: Princeton University Press, 1965). 
Harriott's description of the NE inhabitants, the population in Pennsylvania (at least) was described as ignorant. ${ }^{20}$

Travelers describe the Southern states as being very similar to each other and having a social structure that was more rigid than that of the north with two distinct classes: lower and upper. ${ }^{21}$ However, similarly to the Middle States, the population was mixed. There were the Scotch-Irish who had come from Scotland, the North of England and Northern Ireland and were mostly indentured servants who initially moved to Maryland, Virginia, and North Carolina and then to the Appalachian region. ${ }^{22}$ There were French families in Baltimore who had arrived from the West Indies. ${ }^{23}$ There were also many slaves (40\% of the population of Maryland by the end of the 18th century). According to travelers, the black people in the South spoke good English; ${ }^{24}$ but were less skillful than Native Americans as sawyers, carpenters, smiths, and coopers ${ }^{25}$ while the Native Americans living in the south are described as less aggressive than the ones in the north but reported to hate black people. ${ }^{26}$

The poor in the South were characterized as ignorant, addicted to drinking, to horseracing and to swearing by St. John de Crèvecoeur. ${ }^{27}$ On the other hand, the upper classes in Virginia and North Carolina reportedly maintained a closer connection with Britain than the other states did. In fact, Jones ${ }^{28}$ describes Virginia as "the most valuable gem in the Crown of Great Britain" and mentions that the Virginians were identical in costumes to Londoners: they sent their sons to be instructed in England and read fine works. Moreover, they did not understand sailors, dealers and servants that come from towns in rural areas of England and Scotland.

In any case, expansionism started in 1803 with the Louisiana Purchase and saw its revival in the 1840s with the annexation of Texas and the Gold Rush. On the other hand, external migration was shortly interrupted during the first years of the ER but restarted in the 1830s when people seeking for freedom and better life conditions arrived in the U.S. coming mostly from Britain, Ireland, Germany,

20. D. Ford, Journal of an Expedition Made in the Autumn of 1794, 1794.

21. W. Bartram, Travels through North $\mathcal{E}$ South Carolina, Georgia, East $\mathcal{E}$ West Florida, the Cherokee Country, the Extensive Territories of the Muscgulges, or Creek Confederacy, and the Country of the Chactaws (Philadelphia: Printed by James \& Johnson, 1791); H. Jones, The Present State of Virginia (London: J. Clarke, 1865).

22. J. Algeo, The Cambridge History of the English Language, 2001, 13.

23. J. H. St. John de Crèvecoeur, Letters from an American Farmer, 1782, 301.

24. H. Jones, The Present State of Virginia, 1865; J. H. St. John de Crèvecoeur, Letters from an American Farmer, 1782.

25. H. Jones, The Present State of Virginia, 1865.

26. Ibid, 4-17.

27. J. H. St. John de Crèvecoeur, Letters from an American Farmer, 1782, 215.

28. H. Jones, The Present State of Virginia, 1865. 
France, and Scandinavia (599,000 immigrants from 1831 to 1840 and 1,713,000 from 1841 to 1850$)$.

Indeed, in the second half of the 18th century, Europeans entered through NE and New York and eventually moved to Ohio. Later, people from NE (Yankees) moved into Michigan and Chicago while Pennsylvanians migrated to Carolina, Georgia piedmont and to the southern mountains. In its first years, the population in Texas was composed of people coming from every part of the United States, mostly southerners to the lowlands and northerners to the interior. At the time, St. John's Parish (Louisiana) consisted chiefly of families who came from South Carolina ${ }^{29}$ whereas cities like Mobile (Alabama), Pensacola (Florida) and St. Louis (Mississippi) were inhabited by French families and emigrants from the Northern states. Additionally, the population in New Orleans was "made up of all nations, tongues and languages" and, even though there was internal migration in the early $19^{\text {th }}$ century to places like Ohio, Wisconsin and Michigan, emigrants from Europe were numerous. ${ }^{30}$ Germans, for example, who had entered through Baltimore, New York, Philadelphia, and New Orleans, made up one fourth of the inhabitants of Cincinnati in 1850. ${ }^{31}$

Considering the reasons, mechanisms and consequences of the expansion is relevant to the study, given that migration and territorial expansion can play an important role in the diffusion of changes from one place to another. ${ }^{32}$ Territorial expansion was stimulated by nationalism, religion and the idea of equality among citizens. More territory meant more power for the new nation, at the same time that access to the western land was a way of providing equal opportunities for all to reach individual prosperity. Additionally, many believed that the stretching of boundaries was a divine obligation so the territorial growth was considered blessed by God. As such, the territorial expansion could be seen as a necessity that justified the displacement of Native Americans. In addition, proslavery southerners, moved south because they needed more land to plant.

Although it is a fact that speakers acquire the linguistic characteristics of those they live in contact with, the spread of language features does not depend only on proximity. ${ }^{33}$ There is dominance of town over country, which means that innovations usually spread first from one urban area to another and only later to the countryside. ${ }^{34}$ For those reasons, it is important to emphasize that before 1850, the United States was essentially rural and the few existent cities were small. In

29. W. Bartram, Travels through North \& South Carolina, Georgia, East \& West Florida, 1791, 842-1053.

30. A. A. Parker, Trip to the West and Texas (USA: Concord, 1835), 165-222.

31. J. J. Mersman, The Whiskey Merchant's Diary (ed.) L Fisher (Ohio: Ohio University Press, 2007).

32. P. Trudgill, Sociolinguistics: An Introduction to Language and Society, 2000, 156.

33. Ibid, 43-150.

34. Ibid, 147-149. 
1810, there was no urban center larger than 100,000 and, in 1830, New York was the only city with 100,000 inhabitants. In 1830, Cincinnati was the largest city in the West with less than 25,000 people. The presence of Native Americans was common (and even numerous) in many urban places in Illinois, Louisiana, Mississippi, Ohio, Tennessee and the Florida Territory. ${ }^{35}$ In fact, the influx of migrants helped maintain the extensive contact with other languages, which had been characteristic since colonial times (Native American Languages, African languages, and European languages).

\section{Social Structure and Economic Changes}

This section will present the objective criteria (property and income) that defined economic classes during the period, but at the same time, it will examine the opinions that helped characterize the social classes. ${ }^{36}$ In terms of prestige, farmers were the most prestigious group, followed by the clergy, lawyers, and doctors who ranked the same. Merchants had an intermediate status because, although they were wealthy, they were considered the most dangerous part of the community and were accused of profiteering. The artisans came below the merchants and free laborers, white servants, and slaves occupied the last position. ${ }^{37}$

Although the small farmer was the ideal American, the difference between poor and yeoman was probably imperceptible and depended basically on the fact that the farmers owned their land. In fact, before the 1850s there were few agricultural wageworkers because most farmers "did not have the means to hire them." ${ }^{38}$ Furthermore, in most parts of the country there was no clear distinction between subsistence and commercial farming. ${ }^{39}$ In addition, specialization was rare, for which reason, the local artisans and merchants practiced their trades as sidelines to farming. ${ }^{40}$ On the other hand, merchants and professional men in general were elected more frequently for Congress than farmers and they did not usually join the army while artisans and farmers did. Moreover, there was a difference between the North and the South in terms of access to military ranks.

35. H. Jones, The Present State of Virginia, 1865; W. Bartram, Travels through North \& South Carolina, Georgia, East \& West Florida, 1791; A. A. Parker, Trip to the West and Texas, 1835.

36. J. T. Main, The Social Structure of Revolutionary America, 1965, 197.

37. Ibid, 197-220.

38. J. M. Faragher, "History from the Inside-Out: Writing the History of Women in Rural America," American Quarterly 33, no. 5 (1981): 546.

39. J. T. Lemon and G.B. Nash, "The Distribution of Wealth in EighteenthCentury America," 1968, 17.

40. J. M. Faragher, "History from the Inside-Out: Writing the History of Women in Rural America," 1981, 546. 
In the South, the higher-ranking officers were large landholders while in the North opportunities were equal. ${ }^{41}$

The ER began with a colonial society that was vertically organized and tied together by kinship and patron-client relations ${ }^{42}$ that was transformed during the Industrial Revolution into a country where land no longer guaranteed a relevant position because personal wealth became more important. An agrarian majority opposing an aristocratic minority characterized the first years of the Republic but Jefferson's election in 1800 marked the victory of the rural faction and opened the way to "the appearance of the common man." 43 The social structure of the period after the Revolution was more unequal between 1820 and 1830 than in the beginnings of the 19 th century, ${ }^{44}$ the gap between rich and poor was greater in cities than in rural areas ${ }^{45}$ and there were many differences between the North and the South. New England, for example, did not have a wealthy class, but a subsistence farm society composed of small independent landowners (yeomen) which "gave the impression that everyone in the North belonged to the middle class." ${ }^{46}$ On the other hand, the South had a numerous upper class and only $30 \%$ of freeholders. ${ }^{47}$

Between the Revolutionary and the Civil War, a new commercial nation was born stimulated by the technologies of the Industrial Revolution. At that time, the U.S. underwent an explosive transformation in infrastructure and communication. The postal service (1775), the expansion of the printing industry (1820-1830) and the telegraph (1843) fostered the expansion of education and social reform. Steam boat services (1807) and long-distance railroads (1827) promoted the rise of American industry by powering industries and creating national transportation networks. The opening of the Erie Canal (1825) created a navigable water route from New York City and the Atlantic Ocean to the Great Lakes and greatly enhanced development and economy. Those transformations modernized the nation and enabled an expansion in business stimulated by the movement of goods, money, and people across the nation. The number of business corporations multiplied because buying and selling to locals made people realize that prosperity could come from local trade. ${ }^{48}$ As such, the changes in the social structure during the ER were stimulated by the spread of commerce and resulted in an "egalitarian, individualistic, and money-making society." 49

\footnotetext{
41. J. T. Main, The Social Structure of Revolutionary America, 1965, 212-218.

42. Ibid; G. S. Wood, “The Significance of the Early Republic," 1988, 11.

43. G. S. Wood, "The Significance of the Early Republic," 1988, 6.

44. E. Pessen, "Social Structure and Politics in American History," 1982.

45. Ibid, 1303; J. T. Lemon and G.B. Nash, "The Distribution of Wealth in Eighteenth-Century America," 1968, 23.

46. G. S. Wood, "The Significance of the Early Republic," 1988.

47. J. T. Main, The Social Structure of Revolutionary America, 1965, 7, 18.

48. G. S. Wood, "The Significance of the Early Republic," 1988, 13-14.

49. Ibid, 18.
} 
Main's analysis of the society in revolutionary America in terms of land ownership, income, culture and extent of social mobility results in a detailed depiction of the social structure at the time. According to his description, there was a Lower class that comprised slaves, white servants, sailors, and the industrious poor or ordinary free laborers (weavers, carpenters, coopers, tailors who possessed no land or very small estates). Indentured servants and slaves were the property of their masters. The Industrial Revolution, which modernized the country and benefited the middle class and the elites, did not bring advantages to the laborer. As a result, the working-class children did not normally attend school because they needed to work in factories and married women usually took piecework at home.

The Middle class (or middling status) was the largest and most important group in Revolutionary America and comprised several occupations and professions - small farmers, clergy, artisans, teachers, doctors, lawyers, ministers, etc. In terms of social evaluation, the clergy was respected but had small incomes. Lawyers and doctors had varied incomes and status, but were mostly disliked by the public. Justices and judges were respected by the community, but were disliked by lawyers and had a smaller income than them. The prosperous artisans (cooper, blacksmith, weaver, carpenter), at first, occupied an intermediate position in the prestige hierarchy (below the farmers) but, following the depression of the 1780's, they came to be regarded as essential occupations. Later on, with the Industrial Revolution, artisans and small merchants who owned small factories and stores became the emerging middle class that believed that hard work and education could help them have a better life. Therefore, middle class children and married women did not work. Children attended school so they could acquire the abilities to succeed in life and married women cared for the organization of their homes and the general education and well-being of their children. Additionally, the families began to limit the number of children.

The Upper class consisted of officers (who could have 3 times as much wealth as the civilians), distillers, goldsmiths, large farms owners and merchants. The mercantile class, despite being wealthy, was considered the most dangerous part of the community and did not have easy access to the polite society of the day. However, after the expansion of business in the North, colonial merchants who had traded tea, sugar and other commodities passed their wealth to their children who formed an industrial capitalist elite that distanced themselves from the newly wealthy manufacturing leaders and the growing middle class by promoting marriage between leading families, creating exclusive neighborhoods and social clubs. At the same time, by creating organizations and chambers of commerce they strengthened their bonds and protected their interests. The innovative occupation of business clerk had an important role in the social 
redefinition of economy and was well regarded in society because the aristocracy looked down on manual labor. ${ }^{50}$

\section{Culture and Literacy}

Since language change during the ER may only be approached by examining written documents, another important issue is that of literacy. The ability to read and write during that period is usually measured by the ability to affix a signature in documents - which shows the citizens were minimally literate. Based on town records investigations, Kaestle ${ }^{51}$ and Grubb ${ }^{52}$ conclude that between the 18th and mid-19th century the U.S. was a literate society by European standards. Noticeably, literacy rates were higher for men in the North - about $91 \%$ in the NE and $80 \%$ in the South - and in urban areas. ${ }^{53}$ Additionally, the rate of what is considered full literacy was higher among the upper and middle classes. ${ }^{54}$ However, studies provide incongruent results for female literacy at the time between $45 \%$ and $90 \% .{ }^{55}$ Since formal schooling was not always available, the high level of literacy has been connected to the number of literate immigrants that arrived ${ }^{56}$ and to community or household practices of teaching each other how to read $^{57}$.

Notwithstanding, signature literacy gathered from town records does not provide an exact account of the situation at the time. Wills, deeds, and petitions give only a partial description since those documents are representative of middle-aged or older males of the middle and upper classes, which means that

50. M. Zakim, M. "The Business Clerk as Social Revolutionary; or, a Labor History of the Non-Producing Classes," 2006, 569.

51. C. F. Kaestle, "The History of Literacy and the History of Readers," Review of Research in Education 12 (1985): 11-53.

52. F. W. Grubb, "Growth of Literacy in Colonial America: Longitudinal Patterns, Economic Models, and the Direction of Future Research," Social Science History 14, no. 4 (1990): 451-482.

53. Ibid, 453-475; C. F. Kaestle, "The History of Literacy and the History of Readers," 1985.

54. S. Wilentz, "On Class and Politics in Jacksonian America," Reviews in American History 10, no. 4 (1982): 45-63; C. F. Kaestle, "The History of Literacy and the History of Readers," 1985.

55. R. W. Herndon, "Research Note: Literacy among New England's Transient Poor, 1750-1800," Journal of Social History 29, no. 4 (1996): 963; C. F. Kaestle, "The History of Literacy and the History of Readers," 1985

56. F. W. Grubb, "Growth of Literacy in Colonial America: Longitudinal Patterns, Economic Models, and the Direction of Future Research," 1990, 459-461.

57. C. F. Kaestle, "The History of Literacy and the History of Readers," 1985; R. E. Gallman, "Changes in the Level of Literacy in a New Community of Early America," The Journal of Economic History 48, no. 3 (1988): 567-582. 
evidence for women and lower classes would be scarce..$^{58}$ In fact, white female illiteracy was commonplace until at least the second half of the nineteenth century. ${ }^{59}$

To get a better idea of literacy rate among women, 520 examinations of transients in fourteen Rhode Island towns were analyzed by Herndon. The study showed that females headed $56 \%$ households and that the literacy rate was half of the most conservative estimates between 1750 and $1800 .{ }^{60}$ At the same time, studies of signature literacy in other kinds of documents showed that between 1800 and 1840, 30\% merchant seamen could not sign and that $42 \%$ of the Army enlistees could not sign in 1800, 35\% in 1840 and $25 \%$ in $1850 .{ }^{61}$

Additionally, during the ER, concern with all manifestations of human intellectual achievement increased. ${ }^{62}$ Some of the outcomes were an architectural revolution and the production in the U.S. of pedagogical material like dictionaries and grammars (A Grammatical Institute of the English Language by Noah Webster; The Columbian Dictionary of the English Language by Caleb Alexander; An American Dictionary of the English Language by Noah Webster).

\section{Discussion}

Socio-economic aspects like age, gender, social class, literacy level influence language diffusion and language change. Accordingly, if the formation of regional and social varieties happened during the first half of the 19th century ${ }^{63}$ the intense social, cultural and economic transformations of the ER should have affected the formation of those varieties and their diffusion. At the same time, it is only possible to investigate the diffusion of sound changes in the past through the examination of written documents. Under those circumstances, it is essential that the selected documents are representative of the everyday speech of members of the community ${ }^{64}$ and consist of misspelled words or any feature that evidences a change in pronunciation. Because semiliterate people have a tendency to write

58. F. W. Grubb, "Growth of Literacy in Colonial America: Longitudinal Patterns, Economic Models, and the Direction of Future Research," 1990, 475; R. W. Herndon, “Research Note: Literacy among New England's Transient Poor, 1750-1800," 1996, 963.

59. J. M. Faragher, "History from the Inside-Out: Writing the History of Women in Rural America," 1981, 537.

60. R. W. Herndon, "Research Note: Literacy among New England's Transient Poor, 1750-1800," 1996.

61. C. F. Kaestle, "The History of Literacy and the History of Readers," 1985, 30.

62. G. S. Wood, "The Significance of the Early Republic," 1988, 16-17.

63. M. Montgomery, "The History of American English," 2004.

64. E. Schneider, E. "Investigating Historical Variation and Change in Written Documents," in J. K. Chambers, P. Trudgill and N. Schilling-Estes (eds.), The Handbook of Language Variation and Change (Oxford/Malden, MA: Blackwell, 2002), 67. 
phonetically, the misspellings and words that are spelled in different ways in documents they write are strong evidence to the pronunciation of the time. As such, the primary sources need to conform to some requirements. First, the written material should parallel speech as much as possible, so less standardized material would be more appropriate. Second, the material needs to be representative of all members of the community. In view of that, accessing a multi-genre corpus would contribute with a better perspective; however, different sources have characteristic strengths and weaknesses.

When considering the extent of standardization, as edited collections have gone through manipulation, they would not be useful. Also, historical documents (ex. town records) are standardized and normally represent only part of the population (upper ranks, literate people, men) for which reason they may not contribute much with the investigation. Ledgers may be more standardized if they belong to important companies, or less standardized if they record the trade of retailers or individual artisans. Elocution manuals, dictionaries, grammars and textbooks - especially spelling books - will be valuable as secondary sources because by the 1820s they became resources for teaching spelling not for teaching reading ${ }^{65}$ and provided comments regarding 'correct' pronunciation. Diaries, recipe books and autographed personal letters focus on the content, not on the form, which allows them to be written in a less standardized, sometimes informal, or even careless, style. Literary texts are not standardized but the data they provide may not be trustworthy because poetical compositions and rhyme may be influenced by fashion and rhyming styles. Furthermore, literary conversations may not be a completely reliable source. For example, a 19th century observer expressed that "no American ever spoke like the Yankee on the boards of minor theatres in London" 66 .

Concerning the representation of speech in written form, five categories have been identified. ${ }^{67}$ The first category records speech events exactly, directly and simultaneously (ex. trial records). The second category also records, but from notes or memory (ex. slaves narratives). The third category consists of potential utterances that the speaker/writer records (ex. diaries, letters). The fourth category is similar to the first one, but includes an evaluation of the utterance (ex. prescriptive texts). Finally, the fifth one is the recording of invented speech, as in literary works. Thus, for this study preference will be given to diaries and autographed letters as primary sources because they are not standardized and they resemble speech to a certain extent.

65. R. Altenbaugh, Historical Dictionary of American Education (Connecticut/ London: Greenwood Publishing Group, 1999).

66. M. Schele De Vere, Americanisms: the English of the New World (New York: C. Scribner \& company, 1872), 148-149.

67. E. Schneider, "Investigating Historical Variation and Change in Written Documents," 2002, 72-73. 
However, although there is little correspondence between speech and recipe books, they might also be interesting since they permit the comparison between authors. School notebooks would also be useful because they depict the spelling of learners belonging to all social classes. Ledgers and town records have similar vocabulary which would offer orthographic evidence for pronunciation and may permit comparison between them. Additionally, since town records belong to a highly standardized category the misspellings they might contain would be very revealing.

Whatever the kind of material, there is the need to find out as much as possible about who created them (year of birth, gender, social status, level of education and family circumstances) since biographical data is relevant to ensure that the author is assigned to the correct social group and consequently, that all social groups are represented. For that reason, the primary sources to investigate language change during the ER would include only documents whose author is known and ideally who is semi-literate because those informants would provide instances that are nearer to speech in terms of pronunciation. The literacy level is also relevant because, during the period, literacy was correlated, first with schooling, second with family wealth and third with the population density of the community $^{68}$. However, given that semi-literate citizens belong mostly to the lower classes, having more semi-literate informants will result in an unbalanced data among social ranks.

Another problem that arises is that the proportion of male informants will be bigger than that of women informants. First, because, as it has already been discussed, literacy was less common among women than among men. Additionally, handwritten records and autographed letters written by women in those centuries are fewer than those written by men. ${ }^{69}$ When those exist, they over represent upper and middle class urban women ${ }^{70}$ mainly because, despite the fact that rural women constituted the majority of the female population and had an important role as oral communicators, they were mostly illiterate or lacked the time to write letters and diaries. ${ }^{71}$

Apart from selecting the texts for the investigation, it is necessary to develop a system for classifying the speakers. Traditionally, the system of social classification concerns the access to sources of wealth or power ${ }^{72}$ but in the 18 th and $19^{\text {th }}$ it was

68. C. F. Kaestle, “The History of Literacy and the History of Readers," 1985, 31.

69. J. M. Faragher, "History from the Inside-Out: Writing the History of Women in Rural America," 1981; J. Purvis, "Using Primary Sources When Researching," Women's History from a Feminist Perspective, Women's History Review 1, no. 2 (1992): 273-306.

70. Ibid, 293.

71. J. M. Faragher, "History from the Inside-Out: Writing the History of Women in Rural America," 1981, 537-554.

72. C. Clark, "Comment on the Symposium on Class in the Early Republic," 2005, $557-564$. 
determined by century kinship, occupation, politics and property. ${ }^{73}$ As the social structure is different in different periods of social history, ${ }^{74}$ it is necessary to develop a system of social identification to distinguish the informants by their social class and educational background during the ER. In this article, the proposal of six social classes at any given time in American history ${ }^{75}$ will be used as a starting point. The classification includes an upper-upper class that does not work but hires and supervises those who supervise the labor of others while possessing enough wealth so as to live off in material splendor. There is a lowerupper class which is equal in wealth to the Upper-upper class but has less social acceptability and an upper-middle class which is characterized by living extremely well while the lower-middle class is composed of small shopkeepers, clerks, white collar workers, and small farmers of modest properties who have minimal social influence. The upper-lower class is composed of semiskilled workers and marginal farmers and the lower-lower class consists of tenant farmers, agricultural laborers, and pre-Civil War blacks (in the Early American Republic).

The system of social classification for the study took that classification as a reference and grouped the informants to contemplate the educational background (literacy and access to formal education) and the social changes during the ER. ${ }^{76}$ In addition, the classification observed the characterization of speakers by degrees of literacy and social contact in the Handbook of the Linguistic Geography of New England ${ }^{77}$ which is:

Type I - little formal education, little reading, restricted social contact.

Type II - better formal education (usually high-school) and/or wider reading and social contacts.

73. S. Wilentz, "On Class and Politics in Jacksonian America," 1982; E. Pessen, "Social Structure and Politics in American History," 1982; C. Clark, "Comment on the Symposium on Class in the Early Republic,"2005, 558.

74. J. T. Main, The Social Structure of Revolutionary America, 1965; E. Pessen, "Social Structure and Politics in American History," 1982; M. Zakim, M. "The Business Clerk as Social Revolutionary; or, a Labor History of the Non-Producing Classes," 2006; D. Gilbert, The American Class Structure in an Age of Growing Inequality (Thousand Oaks, CA: Pine Forge Press, 2011).

75. E. Pessen, "Social Structure and Politics in American History," 1982, 12971300.

76. J. T. Lemon and G. B. Nash, "The Distribution of Wealth in EighteenthCentury America," 1968; J. M. Faragher, "History from the Inside-Out: Writing the History of Women in Rural America," 1981; E. Pessen, "Social Structure and Politics in American History," 1982; G. S. Wood, "The Significance of the Early Republic," 1988; M. Zakim, M. "The Business Clerk as Social Revolutionary; or, a Labor History of the Non-Producing Classes," 2006.

77. H. Kurath, et al., Handbook of the Linguistic Geography of New England (Providence: Brown University for the American Council of Learned Societies, 1939). 
Type II - superior education (usually college), cultured background, wide readings, and/or extensive social contacts.

The resulting system for social identification contemplates the existence of a lower-lower class with no formal education and minimal reading that is composed by slaves, white servants, landless laborers and tenant farmers. An upper-lower class composed of marginal farmers and artisans (weavers, carpenters, coopers, tailors) who have very little formal education and minimal reading. A lower-middle class composed of clerks, small merchants, small factories owners, small farmers and prosperous artisans who had better but still limited formal education and wider reading. An upper-middle class composed of manufacturing leaders and large farm owners with better education and wider reading, followed by a lower-upper class composed of people from the industrial and commercial sector like ship owners, officers, and politicians who had formal education and wider reading. Finally, an upper-upper class composed of bankers, wealthy farmers or planters, urban merchants and high-level politicians who had a superior education, cultured background and wider reading. They modelled themselves on the English aristocracy and embodied the ideal of refinement and gentility.

All in all, the organization of the society and, mostly, the importance of the middle class during the ER should be evaluated as a relevant factor influencing the process of linguistic change. At the same time, it may be considered that high prestige and low prestige varieties could be connected to how the different occupations were evaluated by the speech community.

Finally, the examination should also investigate secondary sources consisting of documents that discuss or that indirectly provide information of the linguistic situation at the time: elocution manuals, dictionaries, grammars, literary works and commentaries from travelers. Elocution manuals, dictionaries and grammars provide scholarly evaluation of speech that complements other evidence while commentaries from travelers would supply biased opinions. Moreover, since language changes in different ways in different places, ${ }^{78}$ it is important to access the geographic distribution of variation. In that case, the comments from travelers visiting and comparing the different regions and the comparison of different varieties in instructional material would represent a significant contribution.

\section{Conclusion}

While the social structure of the U.S. has been invariable in terms of number of classes ${ }^{79}$ the particulars of each class have changed in the different historical

78. P. Trudgill, Sociolinguistics: An Introduction to Language and Society, 2000, 81.

79. E. Pessen, "Social Structure and Politics in American History," 1982. 
periods. Therefore, when analyzing linguistic data from the ER the socioeconomic and cultural characteristics of the time should be considered. At the same time, the rivalry between the North and the South and the territorial expansion should be contemplated because they might have had great influence on the diffusion of the language changes. Moreover, due to the need to collect data in texts written by semi illiterate informants, there will be an unbalance in terms of social rank representation. Likewise, it is probable that women will be underrepresented. Finally, the documents should be selected giving preference to texts that are less standardized and more similar to normal speech.

\section{Bibliography}

Algeo, J. The Cambridge History of the English Language. Volume VI: English in North America. UK: Cambridge University Press, 2001.

Altenbaugh, R. Historical Dictionary of American Education. Connecticut/London: Greenwood Publishing Group, 1999.

Bartram, W. Travels through North \& South Carolina, Georgia, East \& West Florida, the Cherokee Country, the Extensive Territories of the Muscogulges, or Creek Confederacy, and the Country of the Chactaws; Containing an Account of the Soil and Natural Productions of Those Regions, together with Observations on the Manners of the Indians. Embellished with Copper-Plates. Philadelphia: Printed by James \& Johnson, 1791.

Clark, C. "Comment on the Symposium on Class in the Early Republic." Journal of the Early Republic 25, no. 3 (2005): 557-564.

Dillard, J. L. Perspectives on American English. The Hague: Mouton, 1980.

Faragher, J. M. "History from the Inside-Out: Writing the History of Women in Rural America." American Quarterly 33, no. 5 (1981): 537-557.

Fisher, J. "British and American, Continuity and Divergence." In The Cambridge History of the English Language, edited by J. Algeo, 59-85. Cambridge: Cambridge University Press, 2001.

Ford, D. Journal of an Expedition Made in the Autumn of 1794. The New York Public Library, 1794.

Gallman, R. E. "Changes in the Level of Literacy in a New Community of Early America." The Journal of Economic History 48, no. 3 (1988): 567-582.

Gilbert, D. The American Class Structure in an Age of Growing Inequality. $8^{\text {th }}$ Edition. Thousand Oaks, CA: Pine Forge Press, 2011.

Grubb, F. W. "Growth of Literacy in Colonial America: Longitudinal Patterns, Economic Models, and the Direction of Future Research." Social Science History 14, no. 4 (1990): 451-482.

Harriott, J. Struggles through Life: Exemplified in the Various Travels and Adventures in Europe, Asia, Africa, \& America, of John Harriott. Dublin: John Exshaw, 1815.

Haugen, E. “Dialect, Language, Nation." American Anthropologist 68: (1966): 922-935.

Herndon, R. W. "Research Note: Literacy among New England's Transient Poor, 17501800." Journal of Social History 29, no. 4 (1996): 963-965.

Jones, H. The Present State of Virginia. NY: Reprinted for Joseph Sabin from 1724. London: J. Clarke, 1865. 
Kaestle, C. F. "The History of Literacy and the History of Readers." Review of Research in Education 12 (1985): 11-53.

Kurath, H. et al. Handbook of the Linguistic Geography of New England. Providence: Brown University for the American Council of Learned Societies, 1939.

Laing, M. "Multidimensionality: Time, Space and Stratigraphy in Historical Dialectology." In Methods and Data in English Historical Dialectology, edited by M. Dossena and R. Lass, 49-96. Germany: Peter Lang, 2004.

Lemon, J. T. and G. B. Nash. "The Distribution of Wealth in Eighteenth-Century America: A Century of Change in Chester County, Pennsylvania, 1693-1802" Journal of Social History 2, no. 1 (1968): 1-24.

Main, J. T. The Social Structure of Revolutionary America. Princeton: Princeton University Press, 1965.

Mersman, J. J. The Whiskey Merchant's Diary. Edited by L Fisher. Ohio: Ohio University Press, 2007.

Montgomery, M. "The History of American English." In Needed Research in American Dialects, edited by D. R. Preston, 1-23. Durham, N.C.: Duke University Press, 2004.

Montgomery, M. "The Crucial Century for English in the American South." In New Perspectives on Language Variety in the South: Historical and Contemporary Approaches, edited by M. D. Picone and C. E. Davis, 97-117. Tuscaloosa, Alabama: The University of Alabama Press, 2015.

Parker, A. A. Trip to the West and Texas. USA: Concord, 1835.

Pessen, E. "Social Structure and Politics in American History." The American Historical Review 87, no. 5 (1982): 1290-1325.

Purvis, J. "Using Primary Sources When Researching." Women's History from a Feminist Perspective, Women's History Review 1, no. 2 (1992): 273-306.

Read, A. W. "British Recognition of American Speech in the Eighteenth Century." In Perspectives on American English, edited by J. L. Dillard, 15-35. The Hague: Mouton, 1980.

Schele De Vere, M. Americanisms: the English of the New World. New York: C. Scribner \& company, 1872.

Schneider, E. "Investigating Historical Variation and Change in Written Documents." In The Handbook of Language Variation and Change, edited by J. K. Chambers, P. Trudgill and N. Schilling-Estes, 67-96. Oxford/Malden, MA: Blackwell, 2002.

St. John de Crèvecoeur, J. H. Letters from an American Farmer. London: For the Author, 1782.

Trudgill, P. Sociolinguistics: An Introduction to Language and Society. London: Penguin, 2000.

Trudgill, P. and R. J. Watts (Eds.) Alternative Histories of English. London/NY: Routledge, 2002.

Twining, T. Travels in America 100 Years Ago: Being Notes and Reminiscences. New York: Harper and Brothers, Publishers, 1894.

Wilentz, S. "On Class and Politics in Jacksonian America." Reviews in American History 10, no. 4 (1982): 45-63.

Wood, G. S. "The Significance of the Early Republic." Journal of the Early Republic 8, no. 1 (1988): 1-20.

Zakim, M. "The Business Clerk as Social Revolutionary; or, a Labor History of the NonProducing Classes." Journal of the Early Republic 26, no. 4 (2006): 563-603. 
Athens Journal of Humanities \& Arts - Volume 8, Issue 4, October 2021 - Pages 325-340

\title{
"Because No One Can Seize me from Behind": Sir Christopher Hatton's Double Portrait and Elizabethan Textual Paintings
}

\author{
By Elisa von Minnigerode
}

\begin{abstract}
Many researchers have emphasised the special use of inscriptions and texts in Tudor paintings. ${ }^{157}$ Especially in Elizabethan times, emblematic images emerge and contain texts which present riddles to their audience, address an implicit or explicit beholder, and also give information about their own function. The enigmatic double-sided portrait of Christopher Hatton serves as an outstanding example of the various relations that texts and images form in this era. Two elements of its composition will be discussed here: the inscription and the depiction of Father Time, both on the verso-side. One, a textual element, forms a unit with the other, a pictorial element. On their own and in combination, both built up a reference to emblem books and sources outside the picture and contextualise themselves in humanistic discourses about opportunity and time. Thus, their exclusive presentation forms a dialogue with the beholder and opens up a meta-level of artistic expression. The ancient pictorial tradition of the God Kairos is addressed in the combination, while it labels itself as a depiction of time. Overall, the object briefly examined in this study is an outstanding example of Elizabethan artistic culture and remains a desideratum in art history.
\end{abstract}

\section{Introduction}

The Elizabethan era has mainly been described as a period "of immense political and religious changes throughout Europe." While literature and music flourished at that time and are well-known today, its paintings are called "curiously unfamiliar". ${ }^{158}$ Especially of portraiture, often called the dominant genre of the English Renaissance, many samples exist today. While an "Englishness" in painting was not yet developed, the portraits designed during the Virgin Queen's reign delivered an unrepeated perceptual quality and took on a completely underestimated role in English art history. Symbolic strategies of depiction emerged, combining mediums and different layers of meaning, creating likeness, representing status, wealth, diplomacy, and power, or proving loyalty. Artists such as Hans Eworth and George Gower created singular emblematic and

"Research Associate, University of Konstanz, Germany.

1. Juliet Flemming, "Wounded Walls: Graffiti, Grammatology, and the Age of Shakespeare," Criticism 39, (1997): 1-30; Roy Strong, The Elizabethan Image: Painting in England 1540-1620 (London: Tate Gallery Publications, 1969).

2. Karen Hearn, "Introduction," in Dynasties: Painting in Tudor and Jacobean England 1530-1630, edited by Karen Hearn (Peterborough: Tate Publications, 1995), 9-10. 
narrative portraits of English courtiers at Queen Elisabeth's court, well known in the discipline of art history. ${ }^{159}$ English portraits show exceptional qualities, unique for European painting at the time: the use of inscriptions, referencing literature within the picture, as well as details of the composition, all these create a narrative aspect and charge the paintings emblematically. Artistic encryptions and codifications create a "slippery secret world of private allusions" and satisfy a "fondness" for puzzles and allegories. ${ }^{160}$

The complicated portrait of Christopher Hatton is one of the most illustrious emblematic paintings and demonstrates the exceptional qualities of images at that time. ${ }^{161}$ Hatton, Elizabeth I's Lord Chancellor, is surrounded by a horoscope. Inscriptions and additional narrative scenes are added to the composition. Painted front and back, it is an image not only to be read as a picture but also to be physically examined as a material object. Its design reveals a complex interplay: the practice of linking the front and the reverse, creating a relation between the material and the depicted. Since both sides cannot be seen at the same time, the reception becomes not only intellectually challenging but physically demanding as well. While several exhibitions and catalogues have acknowledged the portrait's unique quality, only a few researchers have discussed it in detail. ${ }^{162}$ These works already give a good idea of the complexity that this image has. However, a complete interpretation of the iconography, how the portrait was presented and commissioned is still missing.

The present study aims to discuss the outstanding relation that text and image built up in this example. To narrow that approach down, two elements of the composition will be picked out and analysed: the cryptic inscription at the back of the portrait and the representation of Father Time on the same side. How do they reference each other, and how is their connection to be understood? What kind of perception is demanded from the beholder through the distinct combination of a textual and pictorial element? Because I can only discuss singular aspects of the picture here, this study cannot claim to be a complete examination of the object. Nevertheless, it will help to lay the groundwork for further research of this rich and secretive example of Elizabethan painting.

3. Erna Auerbach, Tudor Artists: A Study of Painters in the Royal Service and of Portraiture on Illuminated Documents from the Accession of Henry VIII to the Death of Elizabeth I (London: Athlone Press, 1954).

4. Hearn, "Introduction," 9-10; Mario Praz, Studies in Seventeenth-Century Imagery (Rome: Edizioni di Storia e Letteratura, 1975), 205-2013.

5. Unknown, Double-Sided Emblematic Portrait of Sir Christopher Hatton, c.1580, oil on panel, $96 \times 72.3 \mathrm{~cm}$, Northampton Museum and Art Gallery.

6. The strongest approach is given by C. W. Moseley, "A Portrait of Sir Christopher Hatton, Erasmus and an Emblem of Alciato. Some Questions," The Antiquaries Journal 86 (2006): 373-379. Illustrations are given by Tarnya Cooper, Elizabeth I $\mathcal{E}$ her People (London: National Portrait Gallery, 2013), 88-89. 


\section{Literature Review and Methodology}

For a long time, art-historical research of the Tudor era mainly focused on authorship and artists. More recent works have pointed out the qualities of the objects themselves and worked out their significance in a context of society and time of religious reformation. ${ }^{163}$ Singular portraits have been examined individually rather than generalising them in groups. As one example, Margaret Aston has famously shown in The King's Bedpost how complex an English $16^{\text {th }}$ century painting works in the interaction of inscription and images and how prints were used as sources for the composition. ${ }^{164}$ Text and inscriptions have vastly been identified as symptomatic elements of Elizabethan pictures, which typically refer to the portrait's sitter. ${ }^{165}$ They often contain the sitter's age, sometimes a motto - a kind of slogan of the portrayed person - and the date.

Consequently, these textual elements function as a support of portraiture's function of documenting the sitter in a certain state of his life. Inscriptions as components of the portrait have also been adapted in miniature-making at that time. ${ }^{166}$ Studies like those presented by Roy Strong are very early approaches which analyse the objects by paying attention to the texts in the pictures and valuing the text as more than just an addition to the painted scene. ${ }^{167}$ Yet, the broad spectrum of texts in Tudor paintings and their specific, sometimes individual functions depend on the objects themselves and have rarely been studied. With Christopher Hatton's double-sided portrait as a case-study, this paper's aim is to, firstly, give an example of a highly individual and carefully designed model of the Elizabethan textual image and secondly, to give an understanding of the all-over text-image relation of this literal-flourishing epoch.

At first, a close examination of the text will be presented, and sources of its origin will be discussed. Secondly, the inherent iconography of Father Time will be laid out so that it can be put into connection with the inscription. The question will arise if text and image can be treated separately or, instead, if they form a corresponding bond that creates a special object-function. In a third step, this

7. Tarnya Cooper, Citizen Portrait. Portrait Painting and the urban elite of Tudor and Jacobean England and Wales (New Haven: Yale University Press, 2012), 20-25. Margaret Aston, "Gods, Saints and Reformers: Portraiture and Protestant England," in Albion's Classicism: The Visual Arts in Britain 1550-1660, edited by Lucy Gent (New Haven: Yale University Press, 1995), 181-220.

8. Margaret Aston, The King's Bedpost (Cambridge: Cambridge University Press, 1996).

9. Hearn, "Introduction," 10.

10. Lindsey Cox, "Pleasing 'the Common Sort Exceedingly Well': An interdisciplinary Repositioning of the British Portrait Miniature c. 1520-1650," PhD Dissertation (University of Kent, 2018), 171.

11. Roy Strong, "Elizabethan Painting: An Approach through Inscriptions - Robert Peake the Elder," The Burlington Magazine 105 (1963): 53-57. 
study will look at the role of the audience. Who was the target audience of such an object, and what sort of perception was expected from them? Finally, examining the text-image relation of Christopher Hatton's double-sided portrait will provide a closer reading of this highly complex and understudied image and present an example of how texts and images construct the object beyond the material. However, before a portrait can be examined thoroughly, the sitter has to be addressed as well.

\section{The Sitter and his Portrait: Christopher Hatton}

Christopher Hatton, who has been branded as "the dancing chancellor" by contemporary authors, is one of the less famous figures of Elizabethan court. ${ }^{168}$ Not much is known about his upbringing and entering court. More prominently, his development into one of the Queen's favourites has been discussed and shown in several biographical works. ${ }^{169}$ Hatton and the Queen had a close but not exclusive relationship. Like other of her beloved courtiers, for example, the Earl of Leicester, their connection can be best described as filled with "an emotional quality". ${ }^{170}$ It is known that she used nicknames for him - as she did for other men at her court, e.g. she called Lord Burghley her "spirit"171 - which he responded to and used himself. In letters to her, Hatton called himself her "sheep" and signed his letters with "Lyddes". They sent presents and tokens to each other regularly, ${ }^{172}$ for example, a "true love's knot", ${ }^{173}$ and the Queen used to pay him distinctive attention when he fell ill. ${ }^{174}$ In their correspondence, both used cyphers, possibly as signatures or reminders. ${ }^{175}$ Additionally, Hatton used special writing of the word "EveR", capitalising the first and the last character whenever he wrote it in letters to the court, thus referring to the Queen as 'Elizabeth Regina'. ${ }^{176}$ Overall, it seems that he had a particularly close position to the Queen, which was a known

12. Eric St John Brooks, Sir Christopher Hatton. Queen Elizabeth's Favourite (London: Cape, 1947), 50-59.

13. Nicholas Harris Nicolas, Memoirs of the Life and Times of Sir Christopher Hatton, K. G. (London: Bentley, 1847); Malcolm Deacon, The Courtier \& The Queen: Sir Christopher Hatton and Elizabeth I (Northampton: Park Lane Publishing, 2008).

14. Alice Gilmore Vines, Neither Fire nor Steel. Sir Christopher Hatton (Chicago: NelsonHall, 1978), 20.

15. Thomas Wright, Queen Elizabeth and her times, Original Letters Selected from the Private Correspondence of Burghley [and Others], Volume 2 (London: Henry Colburn, 1838), 201.

16. Vines, Neither Fire nor Steel, 15.

17. Nicolas, Memoirs, 414.

18. Nicolas, Memoirs, 22-29.

19. Illustrated in Nicolas, Memoirs, 25, 28 and 156.

20. Nicolas, Memoirs, 29 and 443. 
fact to her circle. And at the same time, he was regarded as the one medium to communicate her wishes to others. ${ }^{177}$ His unique position already showed when he just entered the court. It was said that the Queen developed favour for him when she saw him dancing at festivities, which caused him to carry his already mentioned nickname of "the dancing chancellor" and formed his historical reputation for a long time. Although not having a degree or academic education, Hatton was very quickly chosen to be a member of the Privy Council. This was an obscure body of carefully chosen men who administrated the government's routine business and held its meetings in secret. ${ }^{178}$ This position would prepare him to become Vice-Chamberlain and later Lord Chancellor. He acquired many estates during his lifetime and most famously rebuilt his family home, Holdenby, in Northamptonshire. He died in 1591, highly in debts and without leaving any children and was never married.

Several portraits of Christopher Hatton from his lifetime survived. Next to a 'textual' portrait of him, created at his appointment as Chancellor of the University of Oxford in the National Portrait Gallery (NPG) ${ }^{179}$, two Miniatures by Hilliard exist, one in the NPG and one in the Victoria and Albert Museum. The most interesting object, however, is the already mentioned double-sided-portrait (Figures 1 and 2). Its provenance is one with many question marks. It is first documented in an auction catalogue from 1929 when it went in the museumcollection at Northampton. Until 2020, it was exhibited for several years at the National Portrait Gallery in London. By whom and when the picture was painted is not clear yet. The most prominent dating-approach was done by Arthur Beer, who has examined the image using astronomical methods and interpretation. ${ }^{180}$ While his approach was not left without criticism, his approximate dating around 1581 is accepted in research. The most significant clue in this matter seems to be the coat of arms on the top right corner. Because of its specific design, it can be assumed that the painting was created before 1588 when Christopher Hatton was made Knight of the Garter (K.G.). As K.G., the garter would have been included in his signs, probably round his shield, which it is not in this particular depiction.

21. Nicolas, Memoirs, 50 and 55.

22. Nicolas, Memoirs, 17.

23. Unknown: Sir Christopher Hatton as Chancellor of the University of Oxford, ca. 1588, oil on panel, 78,7 x 6,35 cm, National Portrait Gallery London.

24. Arthur Beer, "Astronomical Dating of Works of Art," Vistas in Astronomy 9 (1968): $177-223$. 

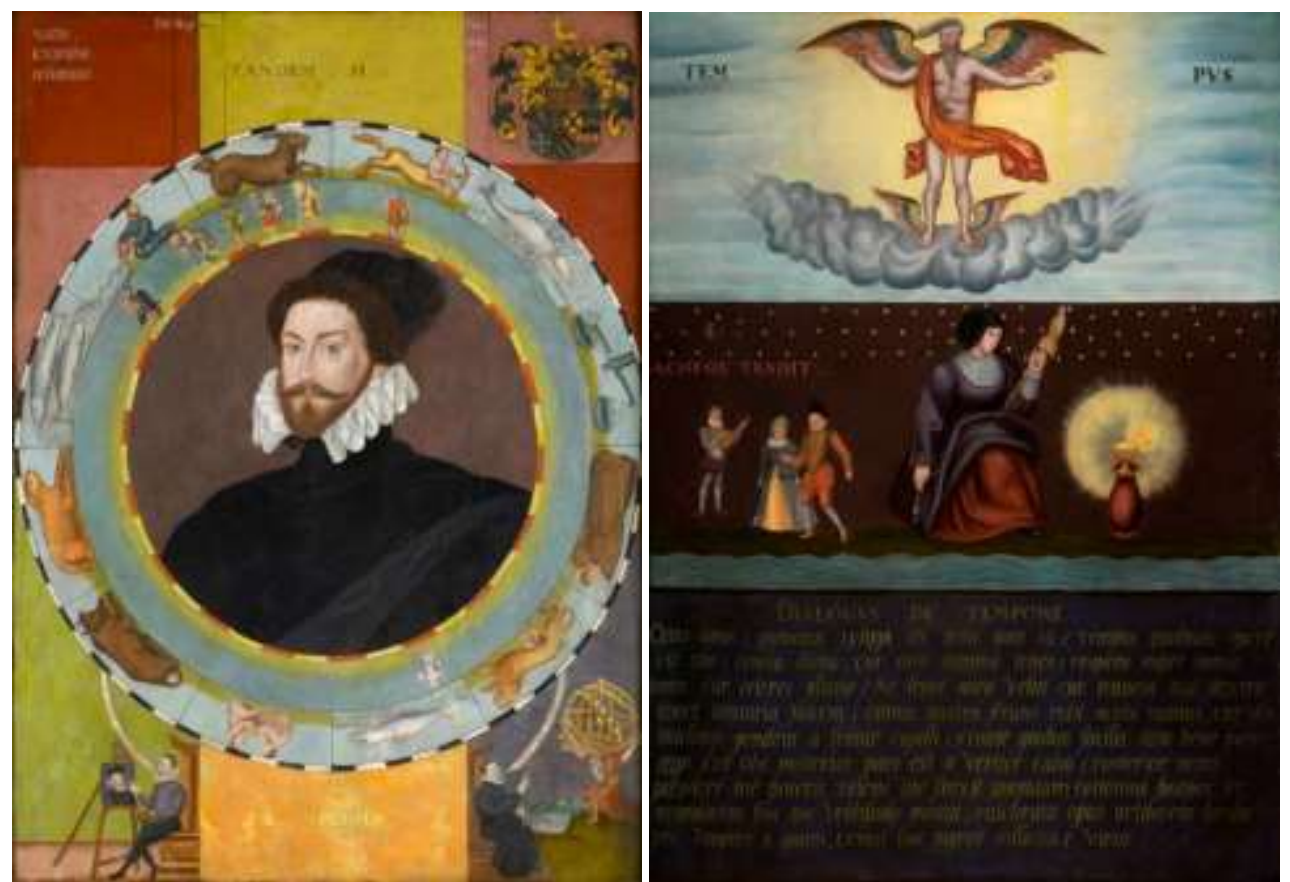

Figures 1 and 2. Unknown: Sir Christopher Hatton, c. 1580, Oil on Panel, $96 \times 72.3 \mathrm{~cm}$, Northampton Museums and Art Gallery, Front-Side (left) and Backside (right) Source: Northampton Museums and Art Gallery.

The portrait-site of Sir Christopher's painting is cryptic at first sight. In the middle of the composition, the later Lord Chancellor is situated in a circle surrounded by a horoscope and astrological rings. Four different circles surround him directly, including the signs of the zodiac and the decans. Hatton's arms are mounted in the top right corner, while two scenes complete the composition in the lower part: A painter working on an easel painting with a portrait of a bearded man, which seems to resemble Hatton and an astrologer with an astrolabe. Several inscriptions are added to the scenery. Both figures at the bottom have labels drawn from their mouths, reminding the modern beholder of word bubbles. The astrologer's label says "[ae]ternitati finiti[s?]" which means either "he destined to eternity" or "he destined from eternity". ${ }^{181}$ The painter's label, on the other hand, says "[ae]ternitati pinxit," meaning "he painted for eternity." The vertical yellowish squares in the middle of the picture contain mottos. At the bottom, the painted area is damaged and thus cryptic, "S[...]i[...]Spesmea" is visible, and in the top centre "Tandem Si" is written, a motto Hatton used in his later career and to which a useful translation is yet missing. ${ }^{182}$ In the top-left, three Latin words are listed, one below the other in invisible rows saying "Natus", "Exaratus", and "Inhumatus" (Born, Raised, Buried). Going to the centre "Die", "Mense", and "Anno" written into columns, complete the left side, while on the right side next to the coat of

25. Moseley, "A Portrait of Sir Christopher Hatton," 373.

26. Brooks, Sir Christopher Hatton, 392. 
arms "Miles Creat[us]: 15" is also written in a column. This part of the painting has been interpreted as incomplete. It is thought to have been intended for, according to the Latin inscription, Hatton's birthdate, date of rising - as Knight, for example - and date of death. If this is an appropriate assumption and why it was left unfinished is not known so far.

The back of the painting shows an allegorical scenery with Father Time standing at the top of the depiction. Beneath him, a woman with a distaff and two figures dancing with a violinist playing music for them are visible. On the right side of this middle-field, a pillar with a chalice spreading spouts of light adds another cryptic element to the composition. While the dancers have commonly been interpreted as a referral to Hatton's reputation as an exceptional dancer and the anecdote that he caught the eyes of Queen Elizabeth while dancing, no conclusion for the chalice has been presented so far. ${ }^{183}$ The rest of the backside is filled with an inscription at the bottom, a cryptic text in Latin on which will be focused on here:

DIALOGUS DE TEMPORE/cuius opus; quondam lysippi dic mihi guis tu; tempus quidnam operae/est tibi; cuncta domo, cur tam summa tenes; propero super omnia/pernix, cur celeres plantae; me leuis aura vehit cur tenuem tua dextra/tenet tonsoria falcem; omnia nostra fecans redit acuta manus, cur tibi/tam longi pendet a fronte capilli, fronte guidem facilis sum bene posse/capi cur tibi posterior pars est a vertice calva; posterior nemo/prendere me poterit, talem me finxit quondam sytiomus hospes, et/monitorem hoc me vestibulo posuit, pulchrum opus artifecem laudat/pro juppiter o guam, debuit hoc pigros sollicita[r]e viros. ${ }^{184}$

This description should already have shown the complexity of the object's design and its potential for investigation. What will be focused on here are the Latin text and the connection it builds up to the figure of Father Time. ${ }^{185} \mathrm{~A}$ fruitful

27. Moseley interprets it as a lamp while Cooper suggests that it is a golden chalice representing the human soul. Moseley, "A Portrait of Sir Christopher Hatton," 378, n. 3.

28. Thanks to restoration work the object is in good condition for perception and the text on the back can be easily read in images. However, multiple publications give a transcript of the text, while not all of them accurate and sometimes misread letters, which is certainly due to the quality of reproductions from the painting. The "sytiomus" in the third line from below in this text is an actual spelling mistake and should be "sycionius" (of Sicyon). Moseley has already transcribed it this way, while close inspection of the painting shows that it is really written as "sytiomus". This leads to the suspicion that whoever painted or re-painted the letters, remembering the condition of the object, were not fully aware of what they were writing. This is, however, no clue into a certain direction as artists and even patrons in $16^{\text {th }}$ century England were not always as fluent in Latin as one might assume.

29. The front-side inscriptions will not be considered on here due to their incompleteness. Especially the "S[...]i[...] Spesmea" is still a riddle to research. While interesting, it does not fit to the subject of text and image that is addressed here in the first 
examination of the depicted personification and an interpretation of the object as a whole cannot be accomplished in this paper. However, a close look at this particular text-image-relation of the painting should be understood as a contribution to solving the painting's history.

The following questions about the text-image-relation on the backside of Christopher Hatton's double-sided painting will be addressed: Is the text somehow describing the depicted? Or is the painted scene an illustration of the written text? This study strives to focus on the text and the image to analyse the dialogue that these two form in this particular object. The double-sided status will lastly show to be a material status that is strengthening the reciprocal relationship that text and image built up here, which is outstanding for the highly textual images in the Elizabethan era.

\title{
Hinting at the Unseen: The Inscription of the Backside
}

Looking at the inscribed text itself is, as such, already a clue to the image's object-history and status. It can be translated into English as:

\begin{abstract}
A Dialogue of Time
Whose work are you? Of Lysippus, once. Tell me who you are. Time. What do you do? I subdue all things. Why do you so occupy the highest place? Swift, I hurry over all things. Why are your feet swift? The light breeze carries me. Why does your shearer's right hand hold a slender crescent? My severe hand, as it cuts, makes all things mine. Why do long locks hang from your forehead? From the front, I am easy to be held fast. Why is your posterior part bold at your head? No one posterior can seize me. Of that kind [Lysippus] of Sicyon created me once, visitor, and placed me in this entrance hall as a lesson, a beauteous work praises the artist, oh Jupiter, oh that this was destined to stir up lazy men. ${ }^{186}$
\end{abstract}

The text being written in Latin is generic for the intellectual culture at the Elizabethan court. Moseley and Cooper have shown that this text is unmistakeably relying on a poem printed in Andrea Alciato's Emblem Book (Figure 3). ${ }^{187}$ The

place. Additionally, the object's condition, as said before, makes it hard to identify the motto without a doubt. The area around the line is highly damaged, thus incomplete and would ask for support from art technological research. To show how differently it can be read and completed, Beer presented three possibilities, Beer, "Astronomical Dating," 215. For an elaboration on the motto see Moseley, "A Portrait of Sir Christopher Hatton," 375.

30. The translation provided here is based on the translation of Moseley, "A Portrait of Sir Christopher Hatton," 378, n. 4; and Cooper, Elizabeth I \& her people, 86. Misreadings have been corrected though while alterations were made to provide a more accurate, though less elegant, version of the original Latin words and structure.

31. Andrea Alciato, Emblematum liber (London: Scolar Press, 1995), 14-15. 
entry for "In Occasionem" shows the Latin text in verse, and Moseley has logically demonstrated that there is enough similarity between the two to set them alike when put into verse-form. ${ }^{188}$ Here, the examination is going a step further:

Not only is the text on the image resembling a contemporary emblem book, but the text itself is also of ancient origin and is indeed a variation of the infamous statue of Kairos, which was built by the ancient sculptor Lysippus (400 B.C.). The inscription already hints at this connection when it says the ancient sculptor's name, although one must know who he is to understand what is written. The now lost sculpture was said to have stood in front of Lysippus house in Sycion and had a later added epigram carved in its base, which is said to have been by Posidippuss of Pella (ca. 300 B.C.). As it survives in the Greek Anthology (16.275), this epigram resembles the text of Hatton's portrait in form and content. ${ }^{189}$ Moseley has already stated that Alciato's poem is itself a translation from the Greek Anthology-epigram; thus, the inscription on the painting could have been taken from this source independently. Moseley shows further how many other emblem-books in the $16^{\text {th }}$ century used that poem. ${ }^{190}$ Especially interesting is the version in Geoffrey Whitney's A Choice of Emblem, which was published 1586 in Leiden and presents an English translation of Alciato's "In Occasionem" (Figure 4). ${ }^{191}$ The publishing-year makes it uncertain if the portrait was not completed before Whitney's book came out, but also because Whitney's poem is in English, it does not qualify as a source for the portrait's text. ${ }^{192}$ However, it is crucial to state how the topic of "Occasion" or "Fortune" is present in English discourse and shows how largely humanistic circles in England perceived Alciato. ${ }^{193}$ This becomes important when we go one step further to think about the portrait's relation with the audience. The connection of the figure Karios to the depicted

32. Moseley, "A Portrait of Sir Christopher Hatton," 375-376.

33. "Who and whence was the sculptor? From Sikyon. And his name? Lysippus. And who are you? Time who subdues all things. Why do you stand on tip toe? I am running. And why have you a pair of wings on your feet? I fly with the wind. And why do you hold a razor in your right hand? As a sign to men that I am sharper than any sharp edge. And why does your hair hang over your face? For him who meets me to take me by the forelock. And why in heaven's name, is the back of your head bald? Because none of whom I have once raced by on my winged feet will now, though he wishes it sore, take hold of me from behind. Why did the artist fashion you? For your sake, stranger, and he set me up in the porch as a lesson." Simona Cohen, Transformations of Time and Temporality in Medieval and Renaissance Art (Leiden: Brill, 2014), 201-202.

34. Moseley, "A Portrait of Sir Christopher Hatton," 376-377.

35. Geoffrey Whitney, Choice of Emblemes (London: Lovell Reeve, 1866), 181.

36. This assumption is made because of the unlikelihood that a poem in English would be translated back into Latin with a Latin version existing. Moseley also notices that the portrait's version is closest to Alciato's, Moseley, "A Portrait of Sir Christopher Hatton," 377.

37. Peter Daly, Andrea Alciato in England: Aspects of the Reception of Alciato's Emblems in England (New York: AMS Press, 2013). 
figuration of Father Time in Hatton's portrait will be discussed later. However, it can be asserted that the connection between the subject of "Occasion", which was made in the resemblance in the picture's inscribed poem and the ancient figure of Kairos, who is also called opportunity, becomes stronger through these findings. ${ }^{194}$

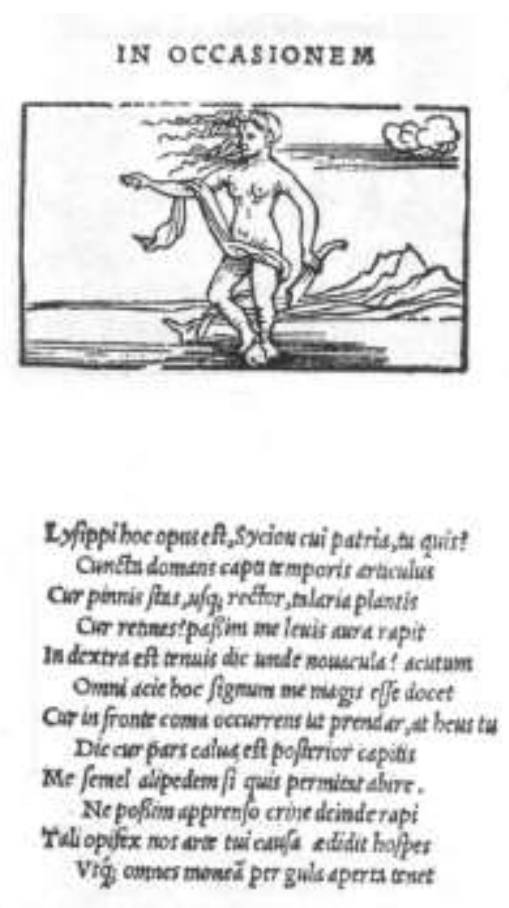

Figure 3. Alciato's "In Occasionem" Source: See Note 31.

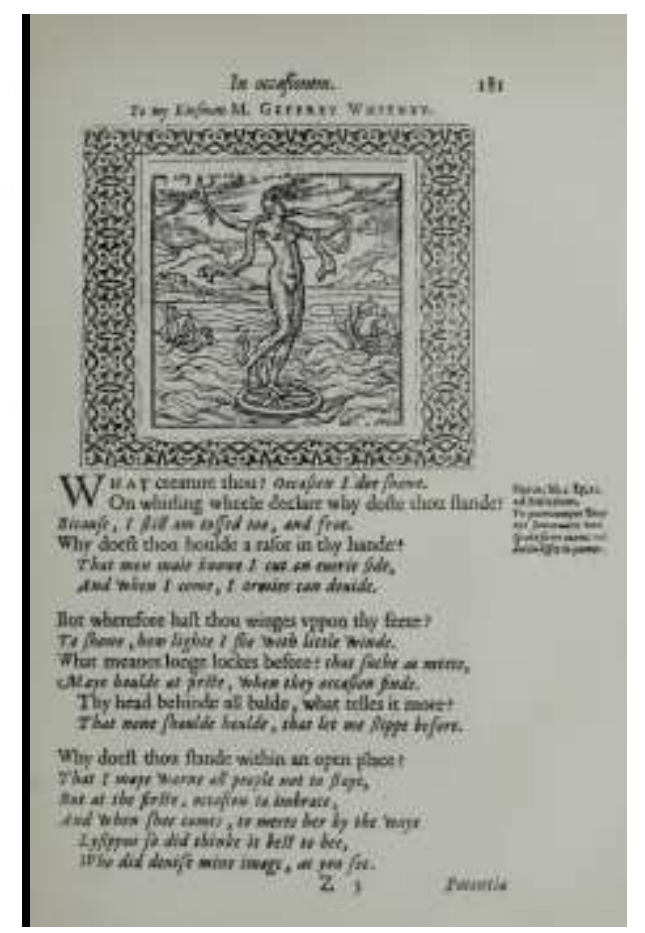

Figure 4. Whitney's "In Occasionem" Source: See Note 35.

Knowing now that the text is not an original invention for the picture, but has its source either in emblem books or in the Greek anthologies in reference to Lysippus' Kairos, gives a hint to understanding the connection of the text to the portrait as an object. Rather than grasping the text as a sort of voice from the image, it becomes a meta-text that speaks about the object's references and the object itself at the same time. The text points to sources outside of the picture as such, which are not apparent to the beholder without a piece of specific knowledge. Especially the part where the answers begin to describe the figure's appearance is interesting. Speaking of a figure with long hair from its forehead and a bold back of his head lets the beholder look up to the father time personification at the top of the panel. When the text says "no one posterior can seize me", simultaneously meaning "no one who is late" and "no one who is behind", the object seems to not only refer to the subject of time but also its own materiality and unique construction. While no one who looks at the backside of

38. Cohen, Transformations of Time, 199. 
the painting can seize its full extend because there is also the front, no one who is late, meaning no one who is born too late - or hasn't gained enough knowledge until the point of observation - can understand the painting's message anymore. Tarnya Cooper's translation of this passage as "because no one can seize me from behind", though neglecting the double meaning of "posterior", seems to grasp this material-describing aspect even better. While this modern perspective on the object may not be a periodically accurate reading, it enables viewing the object's special mechanism when working with an audience.

The text alone charges the picture with an exclusive codification that demands knowledge to be understood. It can already be neglected that the text is only a description of what is painted on the panel, but the question remains if the depicted is not an illustration of the text. A close look at the pictorial elements is now required to get closer to the text-image relation

\section{Image: Opportunity and Time}

Looking at the depiction of the Father Time figure in detail already enlightens its connection to the text (Figure 5). Father Time is an elderly man, naked and only partially covered by a narrow red scarf lying around his shoulder. From his back and his feet, three-coloured wings arise upwards. The figure has a long beard, and an equally long wisp of hair is grown from his forehead. As the figure is only shown from the front, his head's back is only visually indicated to be bald due to the head's slight movement to the left side of the painting. The man's left hand is empty while he holds a crescent-shaped knife in his right hand. With his arms spread to the left and the right, the figure is visually dividing the visual surface, which is met in the separated positioning of the word "TEM: PUS", one part on each side of the figure. If this is designed as a connection to the vertical division of the front-side design in the double-sided painting, has to remain unanswered at this point. 


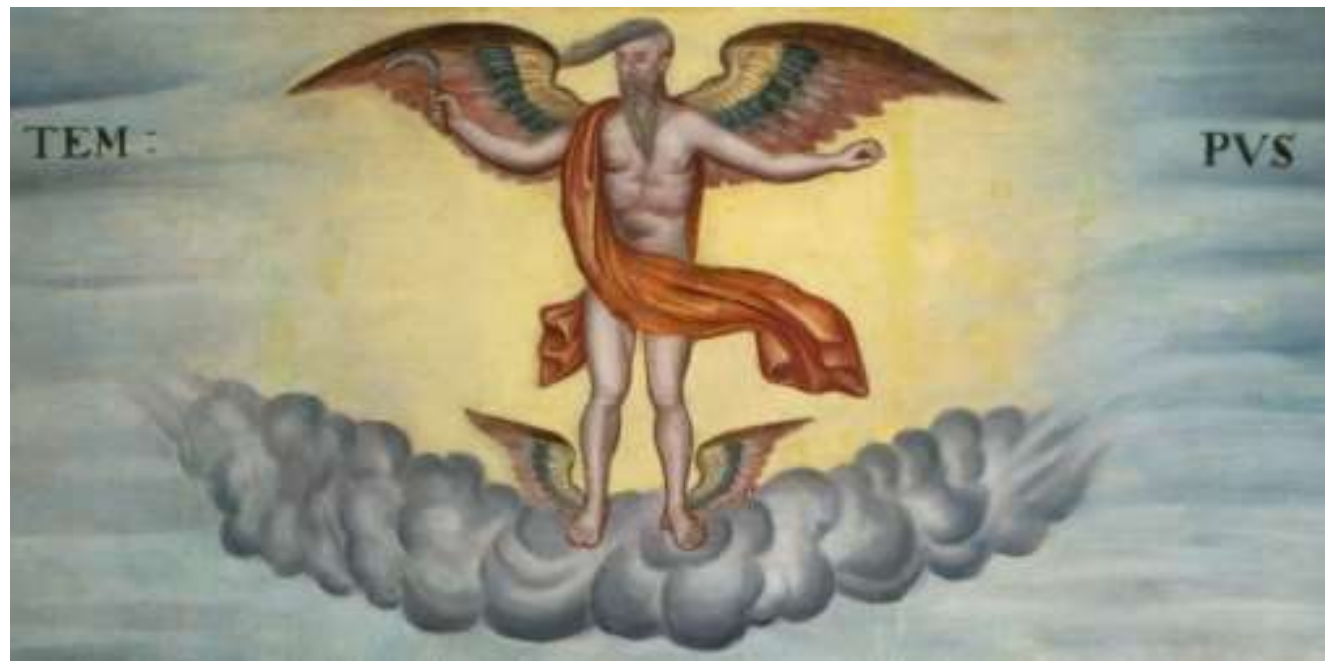

Figure 5. Unknown: Sir Christopher Hatton, c. 1580, Oil on Panel, $96 \times 72.3 \mathrm{~cm}$, Northampton Museums and Art Gallery, Backside, Detail Source: Northampton Museums and Art Gallery.

Overall the expression of lightness, swing and wind is given to the depiction of the figure. The movement of hair, the scarf and the clouds underneath the feat, painted with swift, more and more transparent brushstrokes underline this particular perception. Already, remembering the text, many attributes seem to fit here. When the abstract figure in the inscribed text is asked to comment on its own appearance, it gives information about itself as being positioned at a high place, being swift, holding a knife in its right hand, having long hair hanging from its forehead and the back of the head being bald. All these specifications are met in the figure at the top of Christopher Hatton's picture's backside. But what exactly is presented here? It has already been worked out that the text derives from sources addressing "Occasione", the opportune moment, while this figure is entitled "Time". Additionally, the sources mentioned present different depictions in their emblems. Both Whitney and Alciato present naked long-haired women as figurations (see Figures 3 and 4). A more in-depth look into the iconography is needed to understand the connection of text and image in the double-sided portrait.

In his Studies in Iconology, Erwin Panofsky has given the groundwork description of the personification of Father Time in art history. ${ }^{195}$ Since then, its development has been researched in detail. The depiction of Time as an old bearded man with wings became prominent in humanistic circles and stemmed from the $14^{\text {th }}$ century. In his Trionfo del Tempo, Petrarch gave an illustrious description of the personification of time and the illustrators shaped this in the picture, which was, after Panofsky, the prototype for further depictions. ${ }^{196}$ While

39. Erwin Panofsky, Studies in Iconology: Humanistic Themes in the Art of the Renaissance (New York: Harper \& Row, 1967), 69-93.

40. Cohen, Transformations of Time, 301-306. 
the God Kairos had been a young man in the ancient world and Lysippus' sculpture is described as a youth, Panofsky traced his blending with the older God Saturn during the end of the middle-ages, resulting in the discussed depiction of an older man, the one illustrated in Christopher Hatton's portrait: Naked, a knife in his hand and a long lock hanging from his forehead, Father Time, who is actually Kairos, is a winged figure above the things.

Concerning the connection with Alciato's poem, it is also interesting to point out a second tradition, where Occasion is depicted in a similar way to Father Time but with a shift of genders. Occasion is presented here as a naked female with long hair vividly flying around her shoulders. Such an illustration can be seen in Alciato's as well as in Whitney's book, while both present the already known attributes: knife, scarf, wind. Thus, the tradition of depicting the Occasion, the opportune time as a woman, was prominent in the times of our portrait. What does that mean for the depicted figure of Father Time in Christopher Hatton's picture and the overall text-image connection? It is not a mere quote of Alciato's emblem. Though referring to or at least resembling his poem, the given figuration follows a different pictorial tradition, which ultimately results in the same conclusion. Though labelled as "Time", the figure, even unintentionally, has a connection to the God of the opportune moment and fortune, Kairos. The same reference is made by the text when it reveals itself as a variation of the ancient Kairos-sculpture inscription. To the presented subject of time, the more specific topic of the right moment is added when we combine the meta-text with the pictorial tradition of the depicted figure. The depiction is making the leap from Occasion, also known as a female in contemporary discourse, to old male Father Time. A dialogue inside the object and between object and beholder is opened, a dialogue between youth and old age, the omnipresence of time, and the right moment's elusiveness. The emphasis here seems to lie on time rather than on the opportune moment. But still, both are present thematically in the portrait. But this leap can only be understood when the connection between text and image is made.

\section{Conclusion:}

\section{The Forming of an Emblem or a Dialogue with the Audience}

Without a doubt, the deriving from Alciato's poem and the close connection to emblems and symbols charge the object and make it a demanding one for the audience. Not only are they required to recognise the poem, if not to understand Latin, they also have to deduce its meaning and thus make a connection to the pictorial elements. At last, he is required to put both sides of the object together in the act of perception. When Moseley speaks of a "tension" that the image builds 
up, it can be described with the findings of this study as the exceptional interplay that the inscribed epigram and Father Time's image develop. ${ }^{197}$

It may appear obvious to state that the dialogue presented in the picture's inscription on the back is itself opening the dialogue between image and beholder in return. However, it is a remarkable quality of the text-image-design that, once read, the text is stimulating the perception to a new perspective on the image. In return, if observed closely, the image is not only illustrating but also completing the text in its own manner. Simultaneously, both elements have their own independent function, but in this special combination, they form a bond in this special object. This distinct text image-relation is enrichening and opening the picture to discourses about humanistic subjects such as the figure if Kairos, Time, impermanence, age and death, to name just a few. Barbara Baert has shown how the subject of Kairos experienced an "Aufleben" in the $16^{\text {th }}$ century humanistic circles. ${ }^{198}$ It remains a task for future research to investigate this development, particularly in Elizabethan England. But even if the content of the inscription and the present pictorial tradition is not known, the composition in which text and image are presented is forming an own picture: With the pictorial element positioned at the "highest place", at the top of the panel, and the text written at the lower part of the panel, the composition is visually imitating the well-known form of the emblem, which is, for example, visible in Whitney's and Alciato's publications (see Figures 5 and 6). The typical construction of positioning of "inscription", "picture", and "subscription" - here title, image, and text - is met and implied in the distinct composition of the picture and would have been more apparent to the Elizabethan beholder of a certain circle.

What has been presented here is a proposition of how to capture a complex object and its intertwined image and text-elements. It has been worked out that in the backside of Christopher Hatton's double-sided portrait, firstly, the text hints to sources beyond the depicted and puts the object in a context of ancient and humanistic discourses. Secondly, the pictures are working as a framework and platform for the text and its given information. They represent the overall applicable contextualisation of Christopher Hatton's life and his representation. Thirdly, picture and text have formed elements inside the object, where they have become indistinguishable, a unit, an emblem themselves. Here, a conversion in the form of a dialogue with the beholder is built up. Of course, as said before, this study does not and cannot claim to capture the object as a whole. Too many things have been left unrecognised and not included in these conclusions. For example, the depiction and mention of Lachesis on the backside, which is a highly cryptic element. Moreover, the whole front-side, including the special composition

41. "[...] the painting becomes text to be interpreted and text becomes visual sign in its own right," Moseley, "A Portrait of Sir Christopher Hatton," 377.

42. Barbara Baert, "Kairos: Nachleben, Ikonographie und Hermeneutik," Das Münster 70 (2017): 144. 
of Christopher Hatton's portrait, could not have been addressed here. Furthermore, the abstract idea of Kairos, Fortune and Occasion seems to fit the biographical legends known about Christopher Hatton. But this remains a clue to the overall interpretation of the portrait. This study remains a segment and an initiator of a more complex and more demanding object, which deserves further research.

\section{Acknowledgments}

This article is based on and part of my doctoral project Image and Secrecy in Elizabethan England at the University of Konstanz. Thank you to the Northampton Museum and Art Gallery for the kind permission to use their images.

\section{Bibliography}

Alciato, Andrea. Emblematum liber. London: Scolar Press, 1995.

Aston, Margaret. "Gods, Saints and Reformers: Portraiture and Protestant England." In Albion's Classicism: The Visual Arts in Britain 1550-1660, edited by Lucy Gent, 181-220. New Haven: Yale University Press, 1995.

Aston, Margaret. The King's Bedpost. Cambridge: Cambridge University Press, 1996.

Auerbach, Erna. Tudor Artists: A Study of Painters in the Royal Service and of Portraiture on Illuminated Documents from the Accession of Henry VIII to the Death of Elizabeth I. London: Athlone Press, 1954.

Baert, Barbara. "Kairos: Nachleben, Ikonographie und Hermeneutik." [Kairos: Afterlife, Iconography and Hermeneutics.] Das Münster 70 (2017): 130-144.

Beer, Arthur. "Astronomical Dating of Works of Art. "Vistas in Astronomy 9 (1968): 177-223. Brooks, Eric St John. Sir Christopher Hatton. Queen Elizabeth's Favourite. London: Cape, 1947.

Cohen, Simona. Transformations of Time and Temporality in Medieval and Renaissance Art. Leiden: Brill, 2014.

Cooper, Tarnya. Citizen Portrait. Portrait Painting and the Urban Elite of Tudor and Jacobean England and Wales. Yale University Press, 2012.

Cooper, Tarnya. Elizabeth I \& her People. London: National Portrait Gallery, 2013.

Cox, Lindsey. Pleasing 'the Common Sort Exceedingly Well': An Interdisciplinary Repositioning of the British Portrait Miniature c. 1520-1650. PhD Dissertation. University of Kent, 2018.

Daly, Peter. Andrea Alciato in England: Aspects of the Reception of Alciato's Emblems in England. New York: AMS Press, 2013.

Deacon, Malcolm. The Courtier \& The Queen: Sir Christopher Hatton and Elizabeth I. Northampton: Park Lane Publishing, 2008.

Flemming, Juliet, "Wounded Walls: Graffiti, Grammatology, and the Age of Shakespeare." Criticism 39, (1997): 1-30.

Hearn, Karen. "Introduction." In Dynasties: Painting in Tudor and Jacobean England 15301630, edited by Karen Hearn, 9-10. Peterborough: Tate Publications, 1995. 
Moseley, C. W. "A Portrait of Sir Christopher Hatton, Erasmus and an Emblem of Alciato: Some Questions." The Antiquaries Journal 86, (2006): 373-379.

Nicolas, Nicholas Harris. Memoirs of the Life and Times of Sir Christopher Hatton, K. G. London: Bentley, 1847.

Panofsky, Erwin. Studies in Iconology: Humanistic Themes in the Art of the Renaissance. New York: Harper \& Row, 1967.

Praz, Mario. Studies in Seventeenth-Century Imagery. Rome: Edizioni di Storia e Letteratura, 1975.

Strong, Roy. "Elizabethan Painting: An Approach through Inscriptions - Robert Peake the Elder." The Burlington Magazine 105 (1963): 53-57.

Strong, Roy. The Elizabethan Image: Painting in England 1540-1620. London: Tate Gallery Publications, 1969.

Vines, Alice Gilmore. Neither Fire nor Steel. Sir Christopher Hatton. Chicago: Nelson-Hall, 1978.

Whitney, Geoffrey. Choice of Emblemes. London: Lovell Reeve, 1866.

Wright, Thomas. Queen Elizabeth and her Times, Original Letters Selected from the Private Correspondence of Burghley [and Others]. Volume 2. London: Henry Colburn, 1838. 


\title{
The Photo-Text in the Mussolini Era
}

\author{
By Carla Rossetti*
}

In the 1930s, Fascism's Mythopoeia found in propaganda photobooks a comfortable space in which to configure itself. The layout of the photobooks draws on the experiments carried out by the editors of "Campo Grafico" [1933 - 1939] and by eclectic personalities like Guido Modiano; with reference to photography, on the other hand, from the modernist style developed by the amateurs of photographic circles reworking the experience gained by the European avant-gardes since the previous decade. All these innovations led to a rethinking of the usual relationship between image and text, gaining a new and a much more dynamic interaction between visual and textual. Through the analysis of some of the most important photobooks of the Fascist Era, the following article aims to show some aspects of the verbal and visual rhetoric which the Fascist regime used to generate an articulated model of the world in which to believe, even if its appearance differed radically from what one saw with one's own eyes or experienced on one's own skin every day. In propaganda photo books, the facts are emphasized, even judged, in order to construct a specious argument that leaves no room for doubt.

\section{Introduction and Literature Review}

The history of Fascist propaganda photography is an emblematic story of how, in the 1920s and 1930s, photography participated in the political events of the Nation, contributing to the construction of an epic and heroic tale of the Italian totalitarianism.

The participation of the photograph was not limited to the figurative investigation of the main appointments of the regime schedule, as well evidenced by the images of the L.U.C.E. Institute, ${ }^{1}$ caged by the compositional conditioning dictated by the ministerial service notes. ${ }^{2}$ Instead, to inspire an enthusiastic

*Phd, Subject Expert, Faculty of Cultural Heritage, University of Salerno, Italy.

1. The National Institute L.U.C.E. - acronym of Unione Cinematografica Educativa was a public institution aimed at dissemination of films for educational purposes. It was established by Benito Mussolini with the Royal Decree of 5 November 1925. To gain insight into the pecularities and the protagonists of the Institute's Photographic Section see: S. Mannucci, La Fotografia dell'Istituto L.U.C.E. Storia e Critica (s.n., s.l., 2014); G. D'Autilia, L.U.C.E. The Italian Collective Consciousness (Rome: Rai Edu and L.U.C.E. Institution, 2014); D'Autilia, Il Fascismo senza Passione. L'Istituto L.U.C.E, in L'Italia del XX Secolo. Le Fotografie e la Storia, edited by G. De Luna, G. D'Autilia and L. Criscenti, 91116 (Turin: Einaudi, 2005).

2. For an accurated analysis of the system of control, censorship and direction of printed activities see: G. Ottaviani, Le Veline del Minculpop: Aspetti della Propaganda Fascista (Milan: Todariana, 1999); N. Tranfaglia, La Stampa del Regime, 1932-1943. Le Veline del 
adherence to a certain vision of the world, it was necessary to resort to visual narration in which the observer becomes the pivot of an emotional experience, participating in, and sharing, what is perceived through the mechanical eye. Not by chance, in an article published in the international magazine "Galleria", photographer Mario Bellavista defined 'fascist photography' as a type of photography capable of idealizing any image of Italian contemporary life. That is, a type of photography, "that gives the mark of the revolutionary spirit with which the fascism has given a new aspect to the country and to life." ${ }^{3}$

To satisfy its apologetic needs, Fascism preferred to use the language of modernist photography, which Italian photographers had developed by studying the European and Soviet avant-gardes. Its verisimilitude, rediscovered and claimed, allowed it to be a witness of a certain historical period; its style, characterized by unusual points of view and a dramatic use of contrasts, made it an instrument that enhanced the natural vision, that is, an instrument capable of capturing aspects of reality. ${ }^{4}$ In this way, photography became an instrument capable of amplifying the physiological abilities of the human eye by capturing aspects of reality that escape natural perception and guaranteeing an aesthetic experience of the world. The essence of modern photography lied in the possibility of telling the world, of making it easier to understand. ${ }^{5}$ Not by chance, in his Discourse on photographic art of the 1932, Gio' Ponti said:

Minculpop per Orientare l'Informazione (Milan: Bompiani, 2005). Furthermore, a telegram of July 31 1925, sent by the Minister of the Interior Luigi Federzoni to the prefects, was found at the Central State Archives of Rome. The telegram laid down a series of rules to avoid the reproduction in print of photographs concerning murders, thieves, adulterers, in order to prevent the risk of diverting public opinion (see ACS, MCP, Gabinetto, Black Chronicle, $\mathrm{b}$. 3 , f. 11, telegram n. 17916). In the Morgagni Documents, then, appears a directive in which it was required to publish only the images of the Duce that revealed his personality in a dignified way (ACS, Agenzia Stefani, Morgagni Documents, b. 3, f. 7, orders of March 18 and April 30,1932). Another service order forbade to publish photographs of soldiers who left their homes saying goodbye to their families (cf. ACS, MCP, b. 185, f. 34, order of 27 July 1935): they were always to be shown in imposing masses, in which the Italian "race", with its pride, boldness and youthful strength, was to be clearly visible (cf. ACS, MCP, b. 75, report of 3 September 1939).

3. M. Bellavista, "Per un'Arte Fotografica al Tempo di Mussolini," Galleria 14, no. 4 (1936): 5 .

4. To gain insight into the history of Italian modernist photography see: S. Paoli, "L'Annuario di Domus del 1943" in Fotografo e Collezionista (Dedicated to Paolo Costantini, Photographer and Collector), edited by T. Serena and A. Paolo Costantini, 99128 (Pisa: Scuola Normale Superiore, Pisa, 1999).

5. In this regard, in an article which comments on the International Exhibition of Photography at the V Triennale di Milano, the graphic and photographer Antonio Boggeri said: "But another absolutely new element, capable of inebriating our virgin sensibility, is conquered by the marvelous images that do not belong to the common and natural domain of our eyes. Outside the limited possibilities of our visual means, we hide images 
Photography ha revealed to us a new aspect of things, it has brought us to a whole new understanding, a whole new sense of them [...] Photographic aberration is our only reality, even our knowledge and our judgment [...], it is a great part of our visual learning. ${ }^{6}$

Conceiving photography as an art that finds its raison d'être when its language becomes functional to communication, made it vunerable to the needs of the regime, which used it to influence common opinion through the financing and the production of propaganda photobooks.

In analyzing these fascinating products of semiotic engineering, one comes up against the ambiguity of the term: according to the critic David Campany, the English expression 'photobooks', commonly used by those who study photographic books, is not an innocent term, because it was created and used to impose coherence in a field where there is none. ${ }^{7}$

In Italy, the bibliography on the subject is still to be written. An early systematization was attempted by Antonella Russo: in her Il Fascismo in mostra she tried to analyze the structural aspects of Fascist propaganda photobooks, without being able to trace its origins and the reasons for its birth. ${ }^{8}$ Four years later, in the magazine "AFT. Rivista di Storia e Fotografia", Giorgio Chiti signed a catalogue of the Italian photographic books published between 1940 and 1980, ${ }^{9}$ but it was only in 2016 that a broader study, embracing ages and geographies of the book even very far apart, was published by Cecilia Piazza. The author tried to cross the uncertain terrain in which the artist's book meets design and production through the use of photography. Although she investigated all the possible variations, the photobook does not seem to be subject to a perfect focus. ${ }^{10}$

that the photograph takes and reveals" (A. Boggeri, "La Fotografia alla Fiera di Milano," Natura 5, no. 3 (1932): 45).

6. G. Ponti, Discorso sull'Arte Fotografica," Domus 5, no. 53 (1932): 285-286.

7. "[...] I rather miss those days before the dubious term 'photobook' became so widespread. It's not an innocent word. It has been welcomed and taken up in order to impose some kind of unity where there simply was none and perhaps should be none. A few years ado I wrote this in the British magazine Source: "The compound noun 'photobook' is a nifty little invention, designed to turn an infinite field (books with photographs in them) into something much more definable. What chancer would dare try to coin the term 'wordbook' to make something coherent of all books with words in them? But here we are. A field needs a name and until we find a better one we're stuck with 'photobook" (D. Campany, "The Photobook: What's in a name? The Photobook Rewiew," Aperture 7 (2014): 3).

8. Cf. A. Russo, Fascismo in Mostra (Rome: Editori Riuniti, 1999), 30-31, 163-184.

9. See G. Chiti, "Il Libro Fotografico in Italia dal 1940 al 1980," AFT. Rivista di Storia e Fotografia 19, no. 37/38 (2003): 78-111.

10. Cf. C. Piazza, Pho-to-Booked. Un Libro con le Foto di 107 Libri con le Foto (Rimini: Digitalprint, 2016), 516. 
However, if we try to leaf through some magazines from the 1930s, we can read articles that offer a more precise description of a photobook and allow us to establish an internal chronology of the genre, marking its evolution. In the early Thirties, the photographic book - or photobook - was considered "an authentic photographic encyclopedia in miniature."11 An early example is undoubtedly L'Italia Fascista in cammino, published in 1932 by the National Institute L.U.C.E. on the occasion of the tenth anniversary of the March on Rome, as a figurative compendium of the activities carried out by the regime. In the preface, Duce himself reveals the pourpose of the pubblication, that is "to pay homage to the Truth and Action as a guide for human beigs provided with good effort." 12 With his words, he conditioned the interpretation of the images that flow in the following pages. Here photography is a reliable documentation and bears witness to the reliability of the opening statements. It plays a subsidiary role, simply illustrating the event or theme narrated. ${ }^{13}$

Instead, in the middle of the decade, an anonymous voice of the editorial staff of "Natura" took note of a change of direction, declaring that "after the examples coming from abroad, in Italy too volumes of a certain importance are published, in which photography is the protagonist for itself." 14

In fact, in the volumes after 1935, the conflict/collaboration between image and word is resolved in favour of photographic reproduction, which, even though it is described by a written text, becomes the protagonist of the layout. Its function is to provide a vision-representation of reality improved by the interventions of the regime, immediately succeeding in captivating the reader that the written text would have struggled to conquer.

Thus, the photographic book, or photobook, becomes "a book [...] in which the main message is conveyed by photographs."15 It tells a different kind of truth from that given by the single frame, a truth that becomes available only in the interstices between the images, connecting art to the mass medium.

11. Rich, "Finalmente un Libro," Il Corriere Fotografico 36, no. 4 (1939): 98. By the same author see also: Rich, "Bibliografia Fotografica," Il Corriere Fotografico 36, no. 2 (1939): 4143 , while on the same subject it is worth mentioning Anonymous, "Il Volto della Nuova Italia,"Il Corriere Fotografico 30, no. 6 (1933): 31.

12. B. Mussolini in L.U.C.E., L'Italia Fascista in Cammino (Rome: Istituto Poligrafico dello Stato, 1932).

13. Also Alfredo Panzini, in the introduction to Axel von Graefe's photographic book, insists on the testimonial value of photography and the need for it to be combined with words that explain its meaning: "The precise and scientific language of the photography needs the kit of the words" (A. Panzini in A. Von Graefe, Il nuovo volto d'Italia (Milan: Mondadori, 1933), s.p..

14. Anonymous, “Libri Fotografici,”Natura 8, no. 10 (1936): 27.

15. M. Parr and G. Badger, The Photobook: A History. Volume I (London: Phaidon, 2004), 6 . 
A photobook is an autonomous art form, comparable with a piece of sculpture, a play or a film. The photographs lose their own photographic character as things 'in themselves' and become parts, translated into printing ink, of a dramatic event called a book. ${ }^{16}$

\section{La Sua Terra (1936)}

The definition of photobook offered by Martin Parr is surprisingly close to what the photographer and animator of the Italian modern photographic movement Guido Pellegrini wrote in 1936. From the pages of the monthly magazine "Galleria" he describes the "book of today" as "a living cultural entity", addressed to be "a sort of film, which is read rather than performed." 17 This kind of definition tries to force the banks of narrative models centred on the domain of the text and which suddently became inadequate to meet the needs of a publishing industry in tune with the spirit of the times. In order to narrate the new and seduce the contemporary audience, the book had to entrust its hermeneutical significance to photography. Consistently with the culture of the gaze theorized since the beginning of the decade, photography mixed the domain of art in search of new expressions of reality, and showed itself more relevant to everyday life.

Going on with his reflections, the author traced an interpretation, "the most genuine," of modern book, characterized by:

[...] a choice iconographic documentation, which accompanies and materializes the most dynamic situations. This documentation, integrated by the graphic characters, perfect in form and style, clear intelligible, must support the periods, enliven the movements described, harmonize comparisons. The modern book reveals fine aesthetic sensations with throbbing, vivid, new and unpredictable images; we will not see the photographs on separate pages, but interposed and joined to the story, so as to 'read' them without taking our eyes off the text. A sentence interrupted by an image forces the reader to see and follow the reading, the 'thread' of meaning, while the thought actively unfolds; the writer is truly supported by the illustration, which gives the book the help of its infinite resources. ${ }^{18}$

A first example that seems to respond to indications of Guido Pellegrini was published in 1936: it is La mia terra (His Land), a photobook created as a supplement to the monthly magazine "Il Rubicone", edited by Giuseppe Massani, director of the magazine and author of all the photographs that appear in it. The account narrated by what its author defines as a "peasant book" 19 correlates the events linked to Mussolini's youth with those of the people who live in the

16. R. Prins, quoted in Ivi, 7.

17. G. Pellegrini, “La Fotografia e il Libro Moderno,” Galleria 15, no. 1 (1936): 3.

18. Ibid.

19. G. Massani, La Sua Terra (Bergamo: Istituto Italiano d'Arti Grafiche, 1936), 7. 
countyside around Predappio, translating the praise of a community into a commendation of the Duce. But the moral, physical, existential distance between the two parts of the story is restored by photographs. The images of Predappio's community are images of faces, of men and women intent on working or gathered together on a public holiday: in short, images that document the life and habits of a small town (Figure 1).

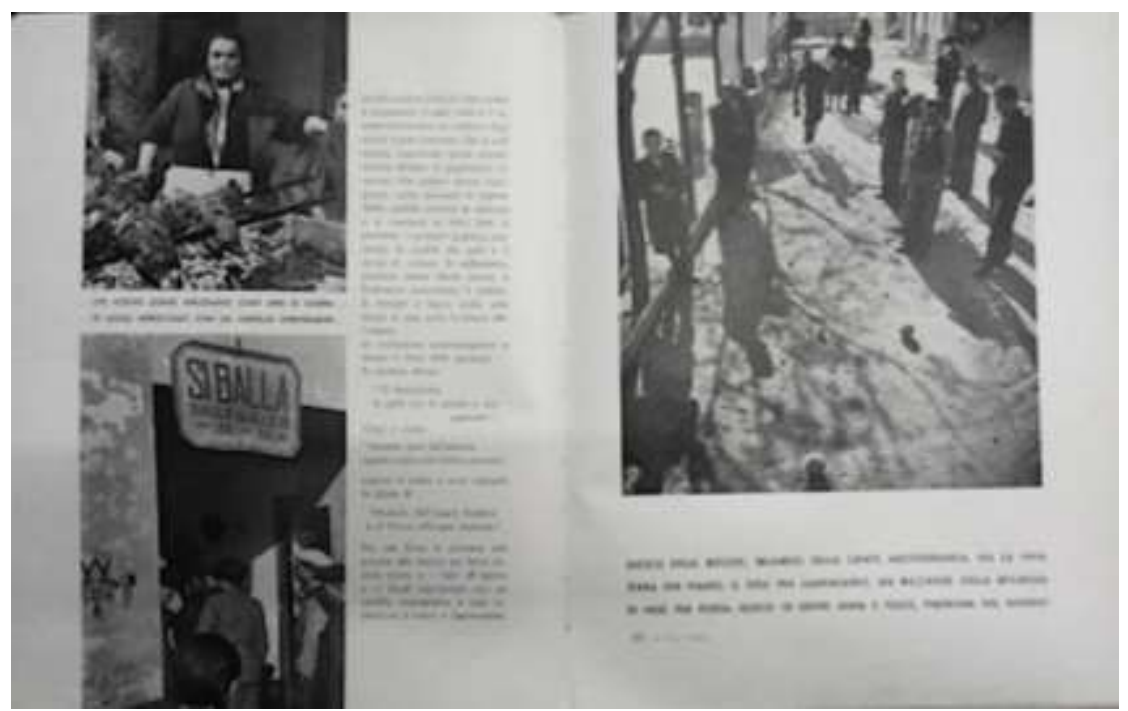

Figure 1. Images of Predappio's Community from the Photobook La Sua Terra, ed. Giuseppe Massani, Istituto d'Arti Grafiche, Bergamo, 1936, pp. 36-37, Private Collection

The Duce's photographs, instead, are not portraits taken from the family album nor hyperbolic official cerimonial poses; rather, they are details of places (the banks of the river Raggi, the Gaiani's house) and objects (beds, blanket, bread, rifle) in which Mussolini hovers like a presence without ever showing himself. This sort of secular figurative consubstantiation contributes to the idealization of the Head of State, creating a psychologically emotional image, capable of impressing the viewer by inducing him to sympathize and mythologize the fascist dictator (see Figures 2 and 3). 

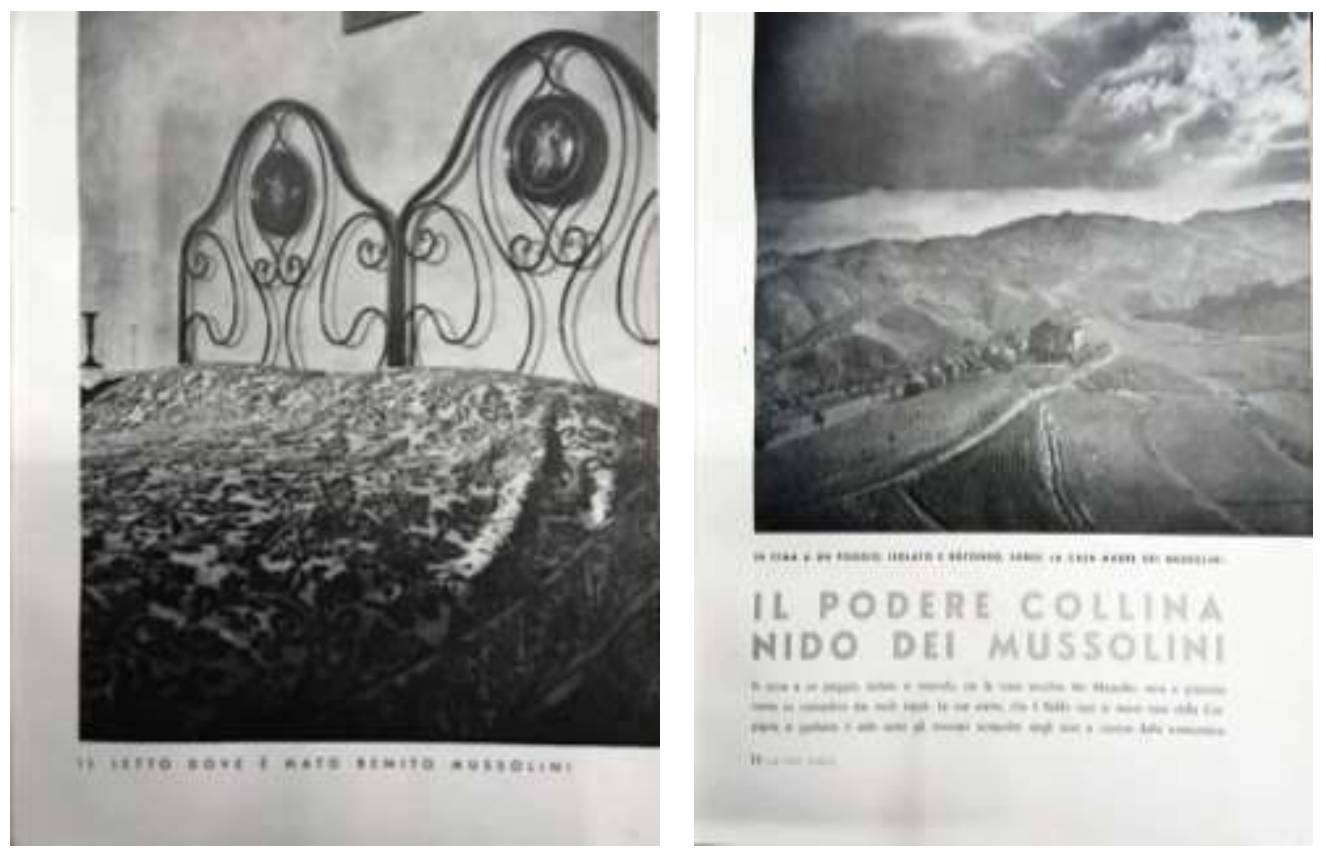

Figures 2 and 3. The Bed where Mussolini Born (on the left) and The Mussolini's Farm (on the right) from the Photobook La Sua Terra, ed. Giuseppe Massani, Istituto d'Arti Grafiche, Bergamo, 1936, p. 9 e p. 11, Private Collection

Another feature that qualifies La sua terra as a modern book is its rendering. As a matter of fact, the possibility of a Fascist Head of State's Mythopoeia had also been supported by the renewal in the typographical environments. It was the critic and printer Guido Modiano who started the debate on the subject. He had travelled around Europe in the Twenties and had become aware of all the experiments of the avant-garde in the field of graphics. ${ }^{20}$ Thus, already in an article of 1931 he had shown that the massive introduction of photography into the mass media had necessarily led to a rethinking of the assumptions on which typographic knowledge was based:

Not only with the contribution of 'illustration' current photography can help us printers. It raises new aesthetics, new decorative means, it proposes clever and tasty solutions to certain problems of decoration. In a typography aware of the new times, decorative motifs must be reduced to a minimum and move away, in what little remains of them, from abused patterns. The photographic taste induces us to replace

20. To gain insight into the history of the graphic design see: P. B. Meggs, A History of Graphic Design (New York: J. Wiley \& Sons, 1998); B. Gomez Palacio and A. Vit, Graphic Design Referenced: A Visual Guide to the Language, Applications and History of Graphic Design (Beverly: Rockport, 2010); J. Müller and J. Wiedemann, Graphic Design: 1890-1959. Volume 1 (Köhln: Taschen, 2019). On the Italian case, cf.: F. Colombo, Libri Giornali e Riviste a Milano: Storia delle Innovazioni nell'Editoria Milanese dall'Ottocento ad Oggi (Milan: Abitare Segesta, 1998); A. Chinellato and C. G. Noventa, La Superficie Bianca. Il Prodotto Editoriale tra Storie e Progetti (Padova: Libreria Universitaria, Padova, 2013). 
the worked frames and the fillers of each style with the superimpositions of screens and texts, which [...] arouse a technical atmosphere. ${ }^{21}$

The two elements of the Italian printer's discourse are therefore connected: in order to better serve its purposes, such as the clarity and the strenght of the message, the typography must enhance and support the structures of the imagine; on the other hand, photography can help graphics to leave old patterns.

Guido Modiano's reflections anticipate the themes of "Campo Grafico" [1933-1939], an Italian magazine of aesthetics and graphic tecnique that aimed to present, among its pages, the whole range of modern typography. ${ }^{22}$ It banned the rigidity of the models inherited from the past and proposed ingenious graphic solutions, which acted as demonstrators of particular design and execution methods. It is no coincidence that in the editorial of the first issue of the magazine, the director wrote:

A technical-demonstrative magazine missing from the graphics field. Through the publication of many practical examples made with clear aesthetic concepts, we support the ideas of the current graphic art and divulge the continuous changes in trends and means in this era of fruitful progression. "Campo Grafico" will be different from other magazines because of its original conception: it will keep a limited number of pages in order to allow a complete change of layout and cover for each issue. The advertising itself will be renewed each time. ${ }^{23}$

So, the typographic revolution had been supported by a heavy penetration of a dynamic and expressive element such as photography into printed production; at the same time, however, the study of the layout became essential in order to support the intentions of the message, promoting a new and stronger connection between image and text.

Going back to La sua terra, in order to improve the relationship between the photographs and the written text, the layout combines the images so as to establish an agreement or, conversely, a contrast between the characteristics of each shot. Words, instead, don't only provide information useful to understand

21. G. Modiano, "Fotografia," L'Industria della Stampa 3, no. 6 (1931): 102. The article has been entirely republished in "Campo Grafico" 2, no. 12 (1934): 274-275. To gain insight into the Guido Modiano's activities, see: M. Chiabrando, "Guido Modiano e la Nuova Tipografia Italiana," in TDM5: Grafica Italiana, edited by G. Camuffo, M. Piazza and C. Vinti (Mantova: Corraini; Milan: Triennale Design Museum, 2012), 60; C. Vinti, “Modiano e la 'Mostra Grafica' alla VII Triennale," Progetto Grafico 4-5 (2006): 50-63.

22. To gain insight into the history of the magazine, see: AA.VV, Campo Grafico: La Sfida della Modernità (Milan: Centro Studi Grafici di Milano, 2003); G. Pellittieri and O. Rossi, “Campo Grafico," Homo Faber 20 (1953): 1-8; C. Dradi, Millenovecentotrentatre: Nasce a Milano la Grafica Moderna (Milan: Ufficio Stampa del Comune di Milano, 1973); AA.VV, Campo Grafico: 1933-1939 (Milan: Electa, 1983).

23. A. Rossi, “Scopi Semplici," Campo Grafico 1, no. 1 (1933): 3. 
the meaning of the visual part: quoting pieces of a Benito Mussolini's book, ${ }^{24}$ they further increase the narrative structure. Moreover, they begin to impose themselves as an image tout court, changing the width and type of character and setting a visual continuity between the pages (see Figure 4).

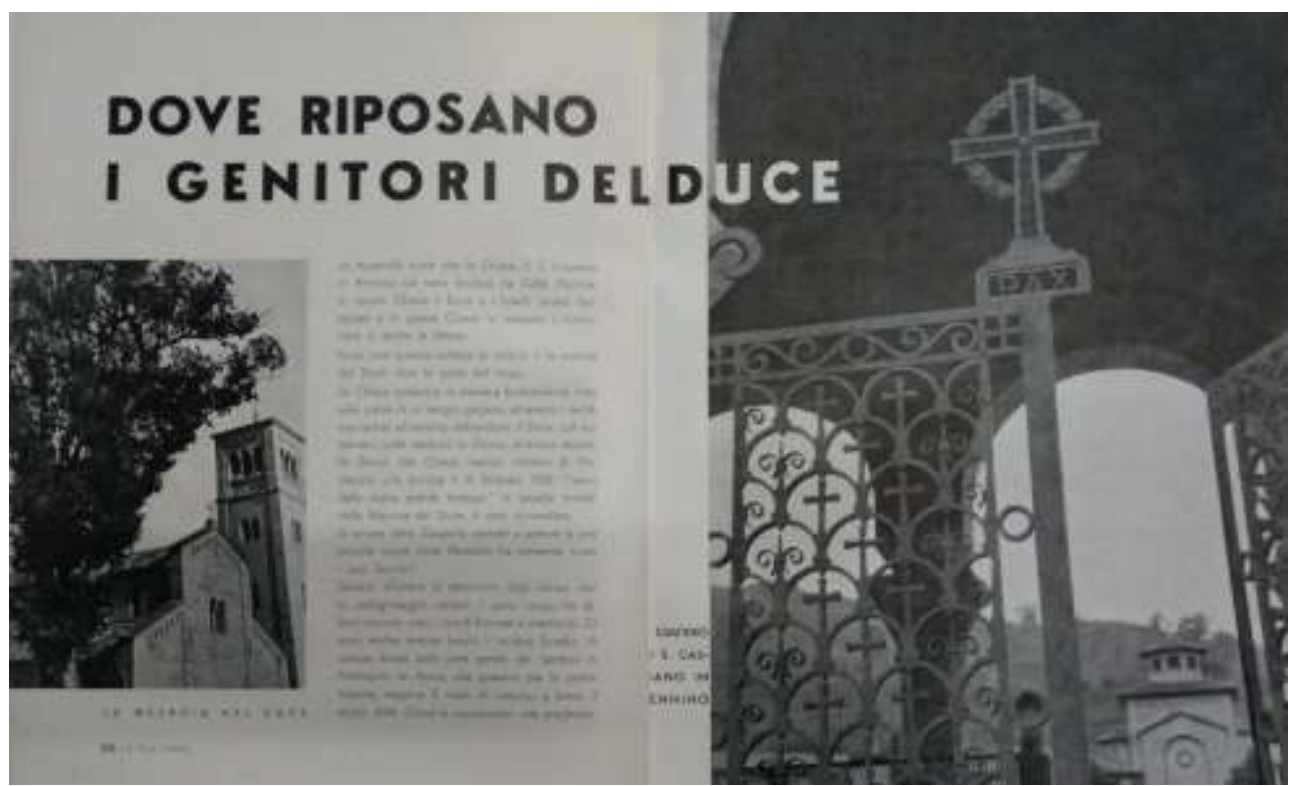

Figure 4. Where the Duce's Parents Rest from the Photobook La Sua Terra, ed. Giuseppe Massani, Istituto d'Arti Grafiche, Bergamo, 1936, pp. 56-57, Private Collection

\section{Italia Imperiale (1937)}

Italia Imperiale (Imperial Italy), the most monumental of the propaganda photobook wanted by Fascism, was announced by a long-lasting advertising campaign in 1936 and was published the following year as supplement to the monthly magazine "La Rivista Illustrata del Popolo d'Italia." 25 The photobook tells the story of Italian ventures in East Africa until the foundation of the Fascist Empire (9 May 1936). His contemporaries considered it "the documentary corpus of political, propagandistic, military, industrial and commercial activities imposed by a single will," 26 organized in order to "make the reader feel all the moments experienced by Mussolini's Italy, make him understand the greatness of certain actions, the importance of the sacrifices made and the results achieved." 27 To realize this ambitious editorial project, it had been necessary to use "a layout that,

24. The reference is to the Arnaldo Mussolini's biography, written by Benito Mussolini in 1932 to commemorate his brother's death. Cf.: Mussolini, Vita di Arnaldo, 1932.

25. The volume is $44,6 \mathrm{~cm}$ long and $37.5 \mathrm{~cm}$ wide, for a total of 624 pages.

26. Anonymous, “Italia Imperiale," L'Ufficio Moderno 13, no. 7 (1937): 341.

27. Ibid, 342. 
by the power of agreements and contrasts, would renovate the enthusiasm of the moments experienced." 28

In Italia Imperiale photographs occupy entire sequences of pages; observing them, one notices the repetition of a characteristic way of shooting that tends to bring the lens very close to the framed object, returning only details of it. This is a device that helps to create icons, to device visual symbols, which more than documenting a fact, contribute to its mythification (Figures 5 and 6).
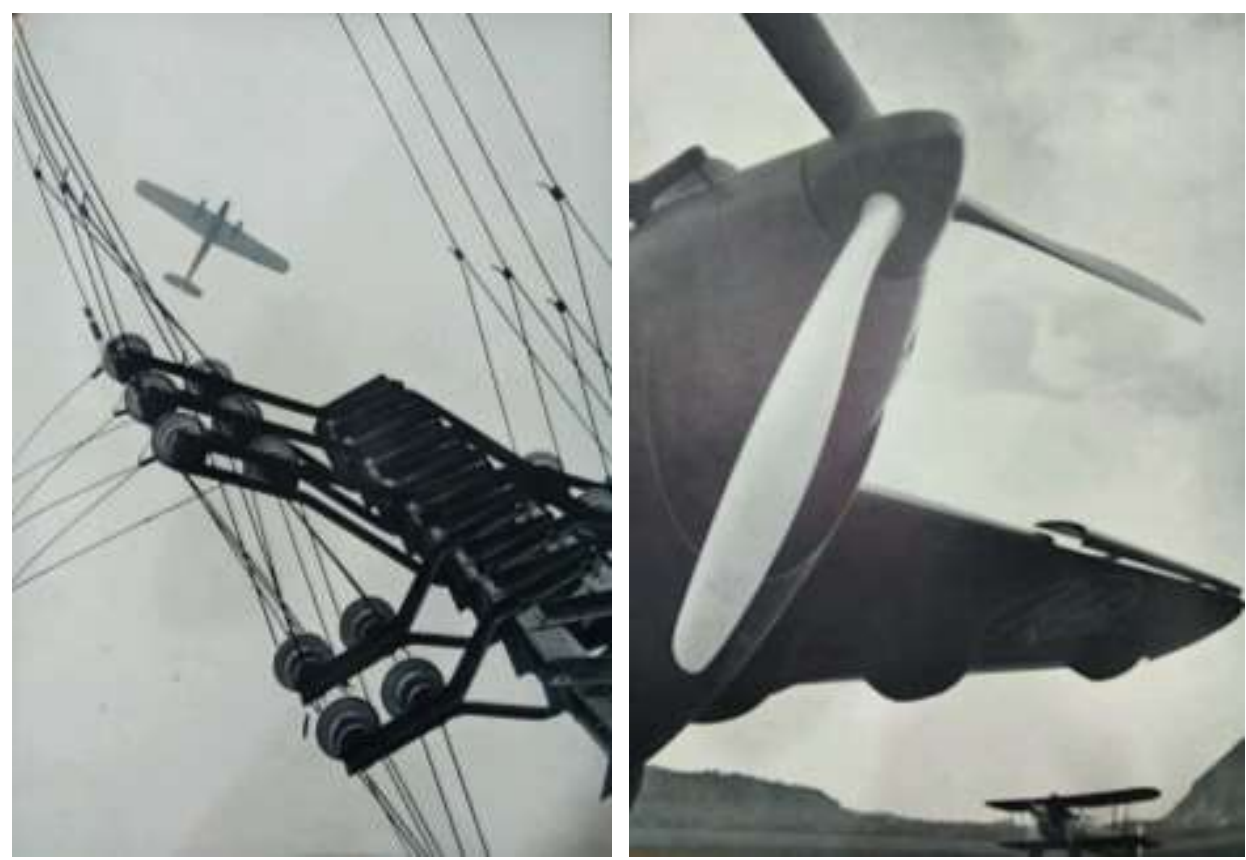

Figures 5 and 6. Some Photographs from the Photobook Italia Imperiale, Curated by Manlio Morgagni and Luigi Poli, Stabilimento Arti Grafiche, Alfieri\&Lacroix, 1937, Private Collection

In the section of the photobook that pays homage to the companies that had supported the African feats by converting all or part of their production, there is a more mature layout than the previous example.

The line spacing and the font size is modified with each topic change. Shortleg characters used when there is a need to contain as much text as possible within the page; on the other hand, elongated characters allow to create a brighter layouts, on which the eye can rest.

When two pages of text follow one another, one tries to break the monotony of the writing leaving wider edges on top and on the bottom of the page. This is a type of layout that betrays the tendency to organize the narrative matter considering the two parts of the sheet as a single one.

28. Ibid. 


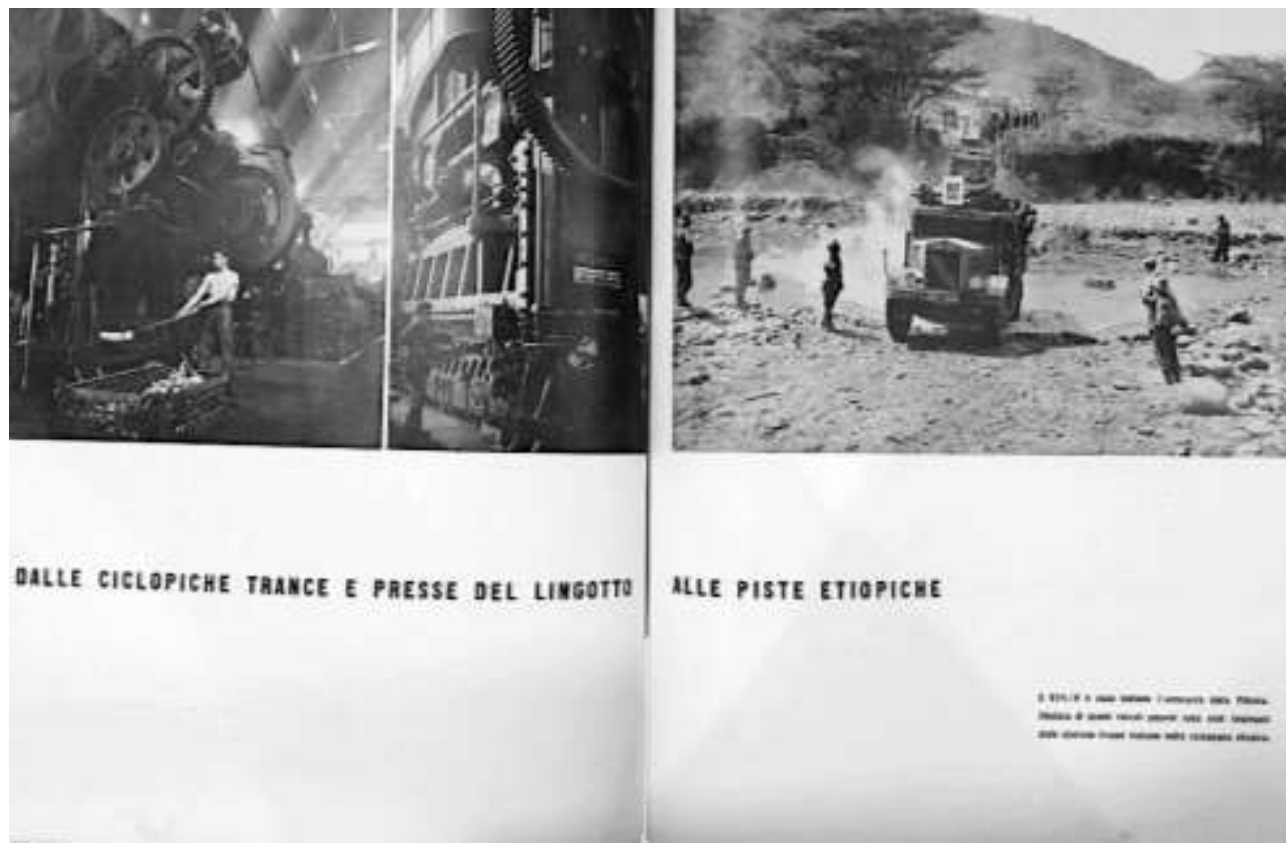

Figure 7. The Mechanical Industry of the Fascist Italy from the Photobook Italia Imperiale, Curated by Manlio Morgagni and Luigi Poli, Stabilimento Arti Grafiche, Alfieri\&Lacroix, 1937, Private Collection

The proposed image can help us to better understand how the graphic choices allow new and more sophisticated interactions between the photographs and the written text. The latter is reduced to a string of letters that crosses the left page to continue on the next one; thanks to the use of bold, the characters acquire a plastic effect and stand out against the surrounding white. Captions and photos are organized according to a mirror structure, where each image - and its tagline - is retired to a page. Nonetheless, they must be read as a whole, because each shot refer to the structure of the other one by contrast or symmetry. In this way, the sequence of terms becomes the geometric center around which the other elements of the graphic composition are arranged. The string clarifies and reveals the game of affinities: with its movement it forces the reader's eye to move on a wider surface while its semantic value strengthens the analogies between the photos, even when they appear far apart (see Figure 7).

Another feature of Italia Imperiale is the presence of photomontages, which often combine documentary intentions and aesthetic qualities, giving a strong added value to the propaganda message. The example proposed here is an assembly work made by Erberto Carboni..$^{29} \mathrm{He}$ realized a hand-drawn diagram of all the forces that made up the Fascist Party, using photographic cutouts (Figure 8).

29. The attribution of the photomontage at issue to the italian architect, designer and advertiser is in: N. Baltzer, Die Fotomontage im Faschistischen Italien. Aspekte der Propaganda unter Mussolini (Berlin: de Gruyter, 2015), 191. 
The transformation of the individual into a symbols had already begun in 1922 with the adoption of the Roman salute by Mussolini's supporters, "greeting of the Latin race, greeting of the legionnaries, with a powerful history and a heroic tradition." 30
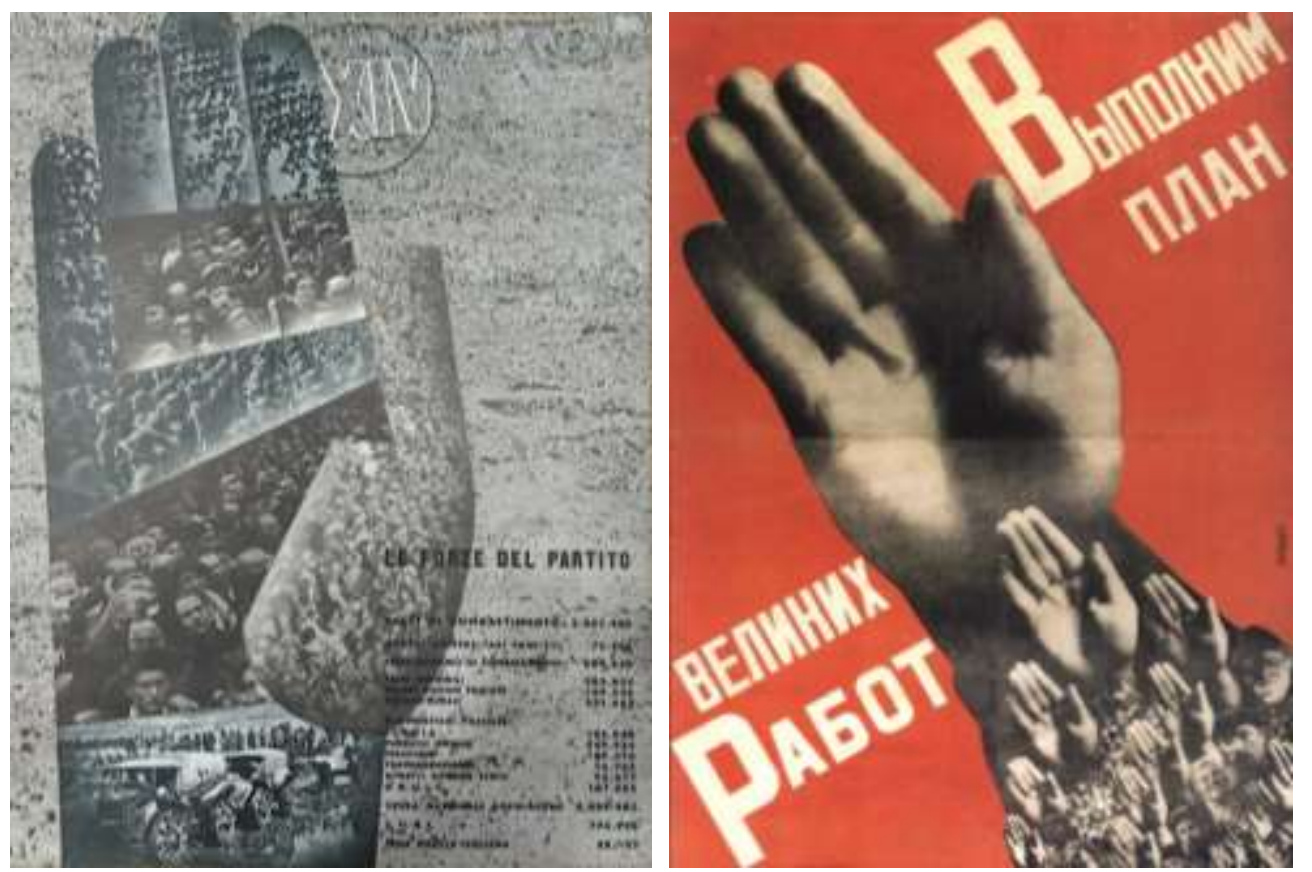

Figure 8. (on the left) Erberto Carboni, Party Forces, Photomontage from the Photobook Italia Imperiale, Curated by Manlio Morgagni and Luigi Poli, Stabilimento Arti Grafiche, Alfieri $\mathcal{E}$ Lacroix, 1937, Private Collection

Figure 9. (on the right) Gustav Klutsis, Manifesto Celebrating 13 $3^{\text {th }}$ Anniversary of the October Revolution, Photomontage from the Photobook Italia Imperiale, Curated by Manlio Morgagni and Luigi Poli, Stabilimento Arti Grafiche, Alfieri\&Lacroix, 1937, Private Collection

However, the iconic motif of the extended hand is not exclusively linked to the fascist ideology: in 1930 Gustav Klutsis used it to make the manifesto celebrating the thirteenth Anniversary of the October Revolution. Also here a large palm stands out against the orange background while small copies of the same images and small heads are juxtapose along the wrist (Figure 9).

In both examples, the photographic icon is documentation and monumentalisation of a thought at the same time; in both examples the large hand shows the way. It is the idea, the symbolic representation of the people as a decision-making apparatus, acting as a unity.

Even the photomontage that closes the chapters dedicated to the corporate system serves to make a theme intelligible by playing on the prevalence of the visual signifier over the verbal one. The system of production planed by the regime acquires mechanomorphic features and opens up its deep metal belly to

30. Starace “Editorial," 1933, 1. 
reveal its functioning: there are tubes that look like oesophagi, valves, cylinders and ladders on which the anonymous mass of the workers rises. At the centre of the image there are two graphically designed cogwheels, which synthesize and corroborate the representation of a well-run economic system through the perfect joint of his gears (Figure 10).

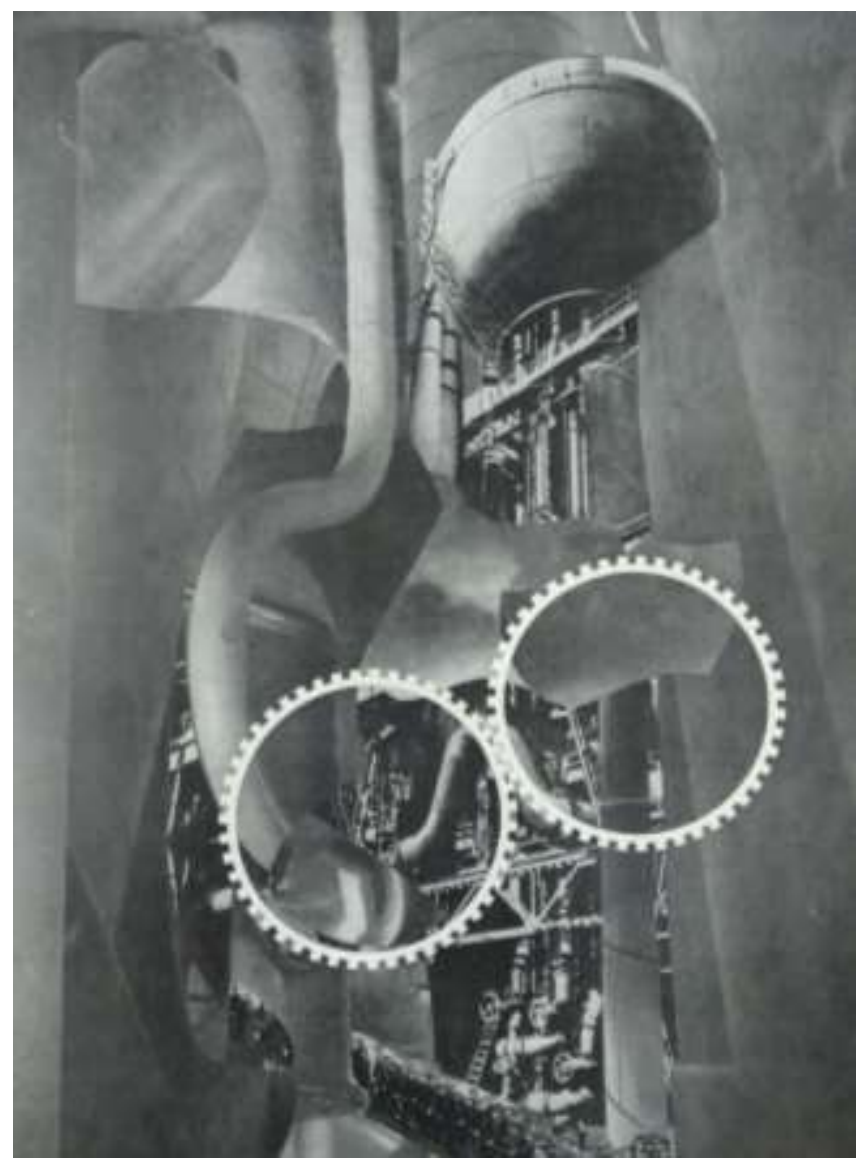

Figure 10. The Corporate System, Photomontage from the Photobook Italia Imperiale, Curated by Manlio Morgagni and Luigi Poli, Stabilimento Arti Grafiche, Alfieri\&Lacroix, 1937, Private Collection

The characteristic of the photomontages in the last pages of the book is a movement induced by curved or diagonal lines: the illusionistic space of the perspective is replaced by the chaotic accumulation of photographic elements, shot from different distances and with different light, to generate a symbolic perspective able of putting together in a page events that take place in spaces and times far apart, as well as in medieval predellas, where each compartment summarized several moments of an action or several moments of the life of a Saint (Figure 11). The suggestiveness of these "manipulation of the reality" 31

31. G. Patti, L. Sacconi and G. Ziliani, Fotomontaggio: Storia, Tecnica, Estetica (Milan: Mazzotta, 1979), 133. 
persuades the observer to firmly believe in the propagated message and amounts to the beginning of a world that would guarantee collective happiness and the population's wealth.

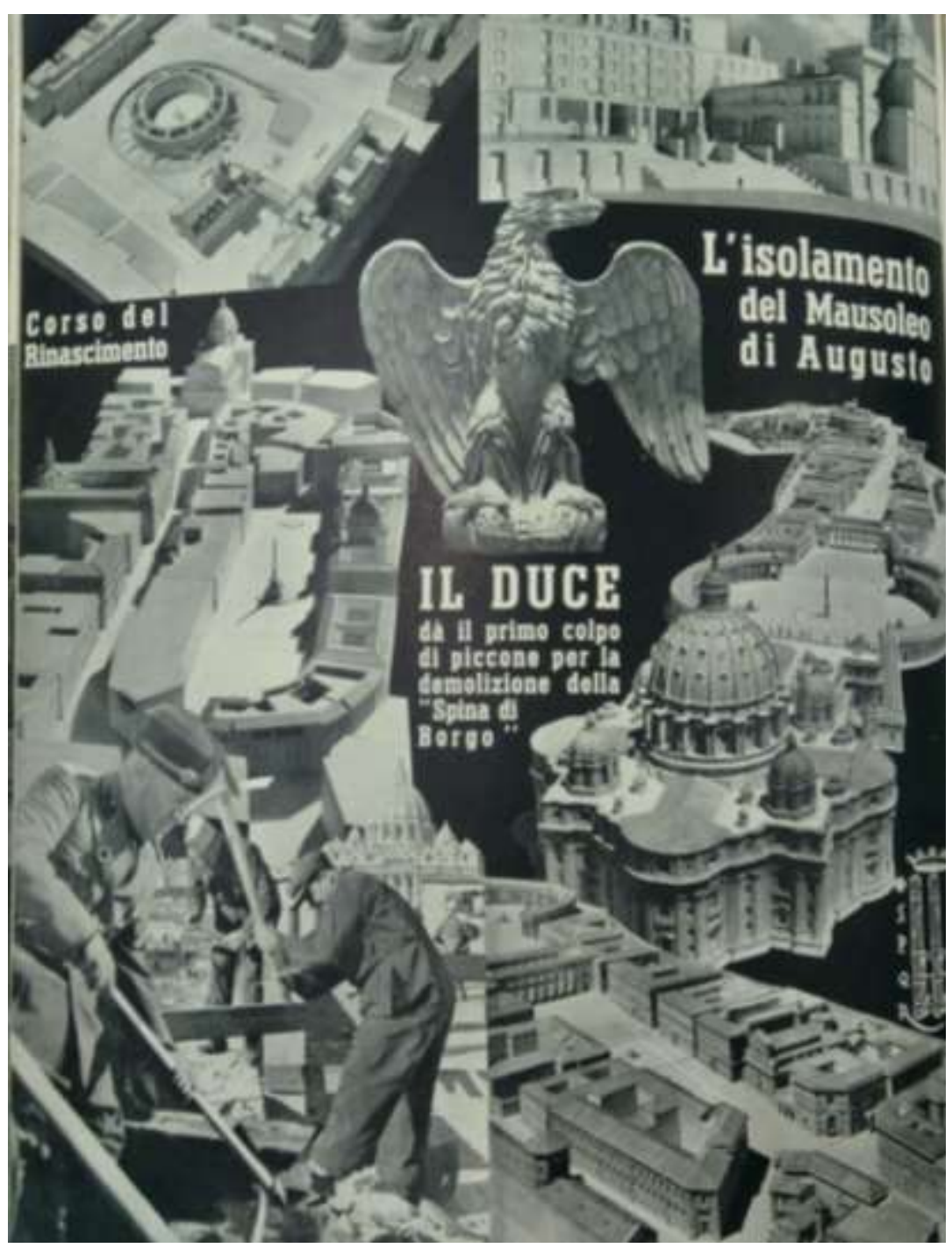

Figure 11. Regime's Construction Project from the Photobook Italia Imperiale, Curated by Manlio Morgagni and Luigi Poli, Stabilimento Arti Grafiche, Alfieri\&Lacroix, 1937, Private Collection

\section{Il Fascio Primogenito (1938)}

The complex interaction between layout, image, word and gaze evolves towards forms characterized by a drastic reduction of writing in favor of an iconic narrative trend in the last photobook suggested: Il fascio primogenito (The first Fascist Lictorian). Published on the occasion of the squadrista's muster in 1939, the volume retraces "the documentation of the most important events that, in every 
sector, had characterized the activity of Milanese Fascism from June 1933 to October 1937." 32

Since in this photo book the text is reduced to a simple introduction, the history of the Party's activities in Milan unfolds through a complex orchestration of visual and figurative elements. Especially the graphic part is well-finished: there are two pages conceived as one and some of them are made up of coloured and transparent plastics, which help to break up the black and white monotony. Often fold-outs are used while the second colour is no longer a pleonastic decoration but a device to accentuate layout values (Figure 12).

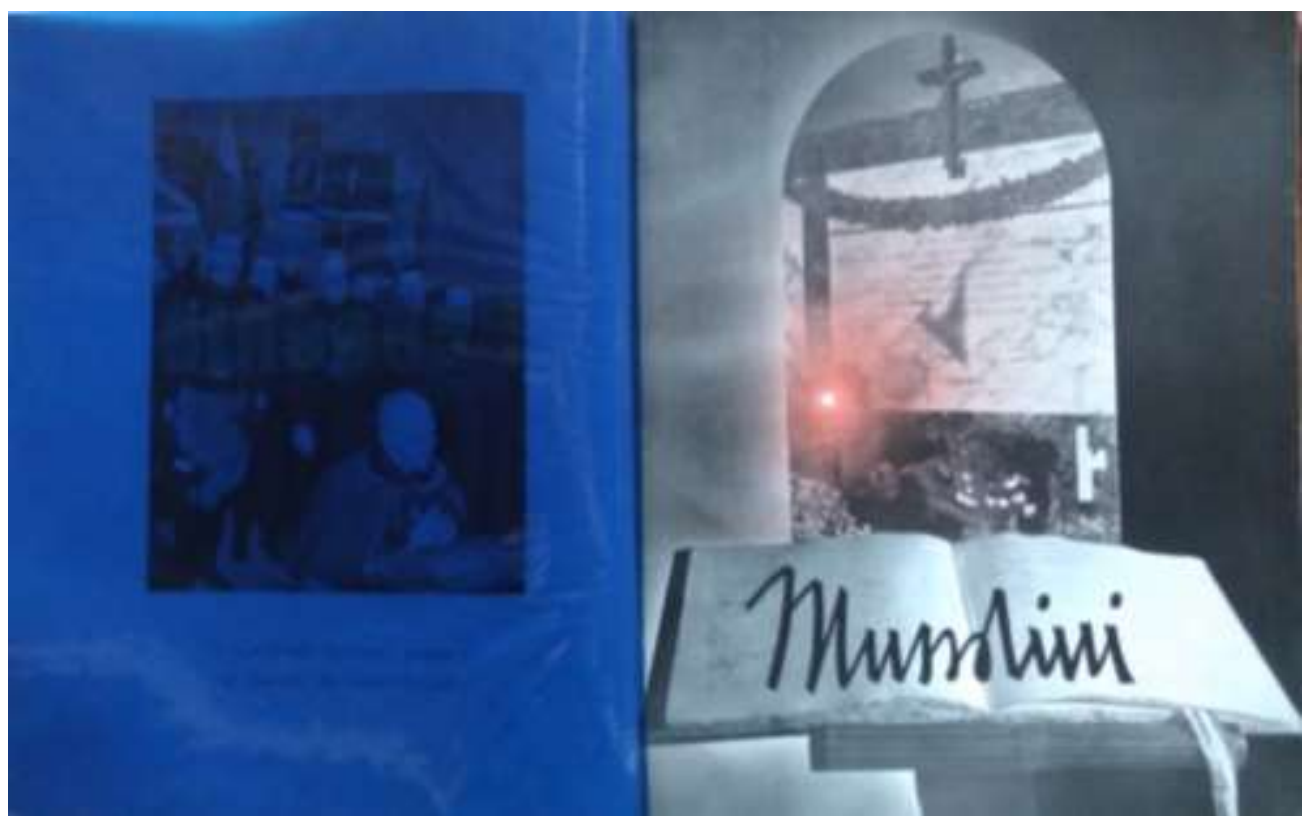

Figure 12. Example of Layout from the Photobook Il Fascio Primogenito, Curated by the Milanese Fascist Party, Officine Grafiche Esperia, Milano, 1938, Private Collection

Also for Il fascio primogenito it can be helpful to scroll and analyze some pages to better understand the visual devices used. One can often come across images where Mussolini appears in the crowd. These are photographs achieved by superimposing cutouts of the Duce to those of the great mass of the people, taking care never to confuse the figure of the Head of State with that of his acolytes. This iconographic choice is based on a certain intention: it abolishs equality in favor of a gap between the Duce and the crowd, "the collective ego in which the individual increases and melts," ${ }^{\prime 33}$ demonstrating to the reader the superiority of the Head of State. In this way, dictatorial power instilled the idea

32. Cf. Milanese Fascist Party (curated by), Il Fascio Primogenito (Milan: Officine Grafiche Esperia, 1938), III.

33. M. Isnenghi, "Iconografia della Stampa Fascista," Belfagor: Rassegna di Varia Umanità 32, no. 3 (1977): 346. 
that the disparity between human beings was not only essential but just (Figures 13 and 14).

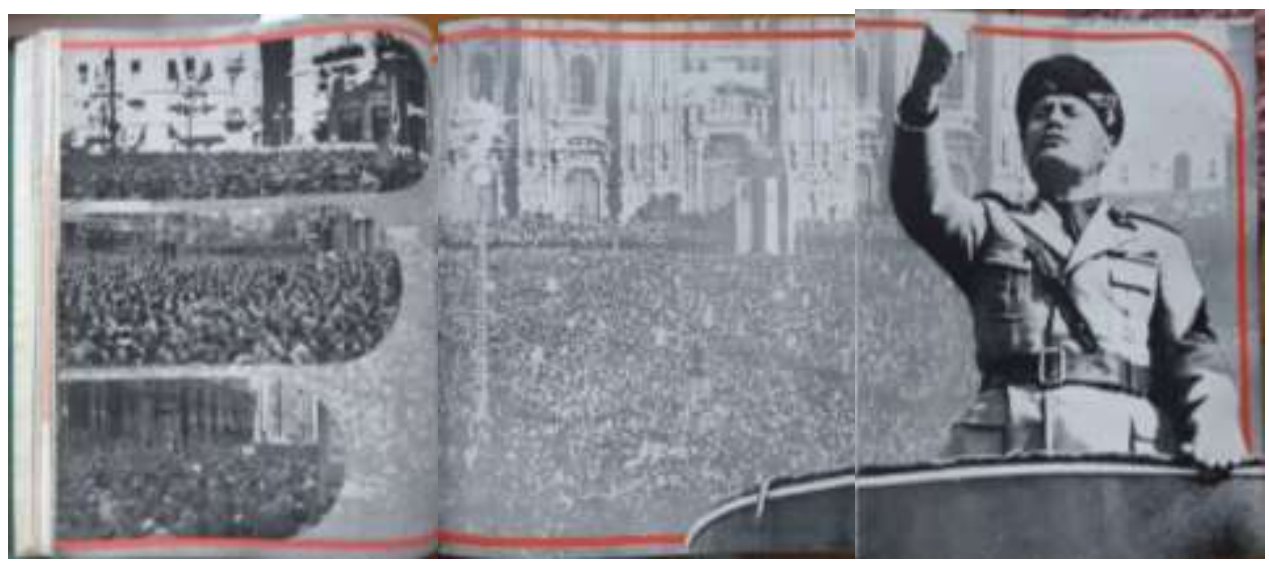

Figure 13. Foldout from the Photobook Il Fascio Primogenito, Curated by the Milanese Fascist Party, Officine Grafiche Esperia, Milano, 1938, Private Collection

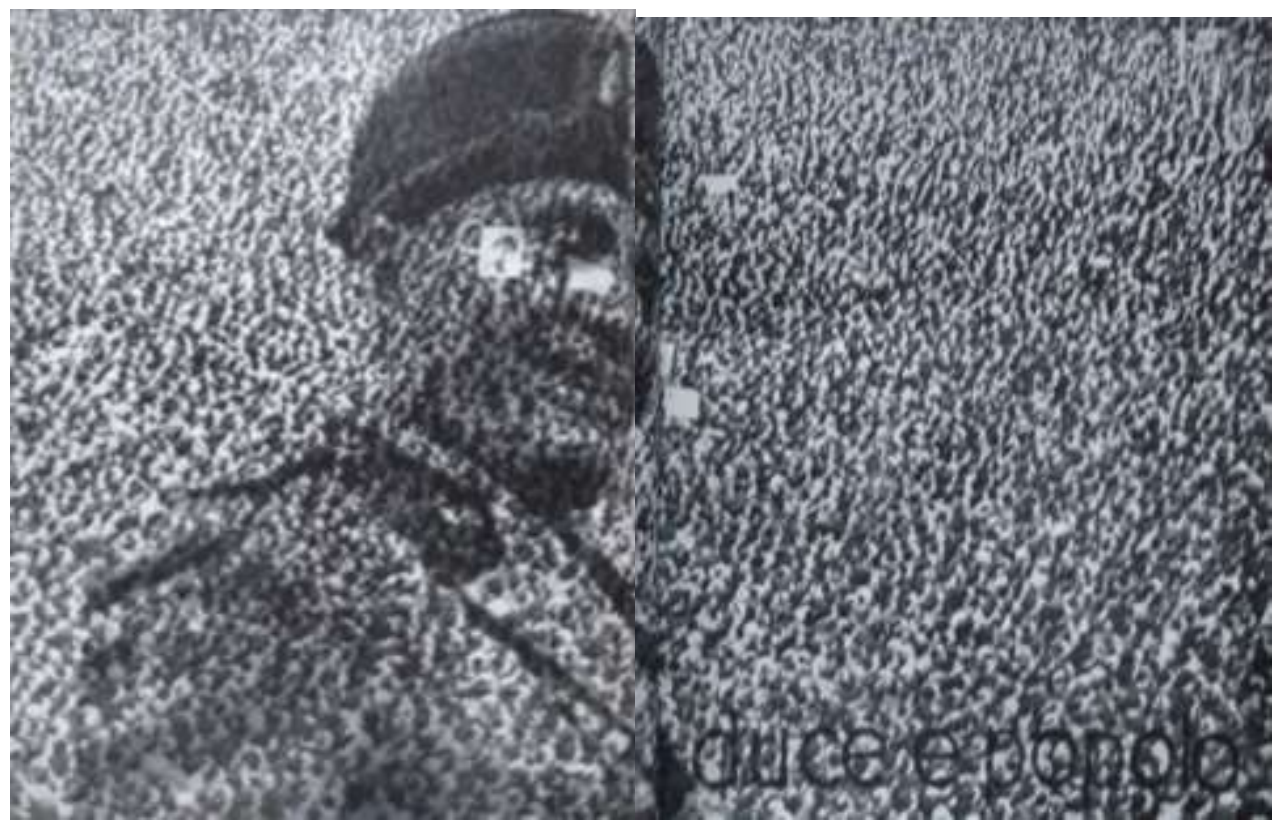

Figure 14. Duce and People, from the Photobook Il Fascio Primogenito, Curated by the Milanese Fascist Party, Officine Grafiche Esperia, Milano, 1938, Private Collection

The pages in which the message is expressed only through combination of visual elements and typographic solutions are new and daring compared to the solutions previously analyzed. The story of the delivery of the wedding rings, when the Italian population was invited to incur war costs by donating their wedding rings, is told through a single image. Here, the typographical elements are arranged in the void of the sheet as a building in the atmosphere and transform white into a concrete and active element. The story takes place through an assembly of a few elements, endowed with great iconic strenght (once again, 
for example, the hand appears) while the colours serve to emphasize parts that surround the events of 8 December 1935 (Figure 15).

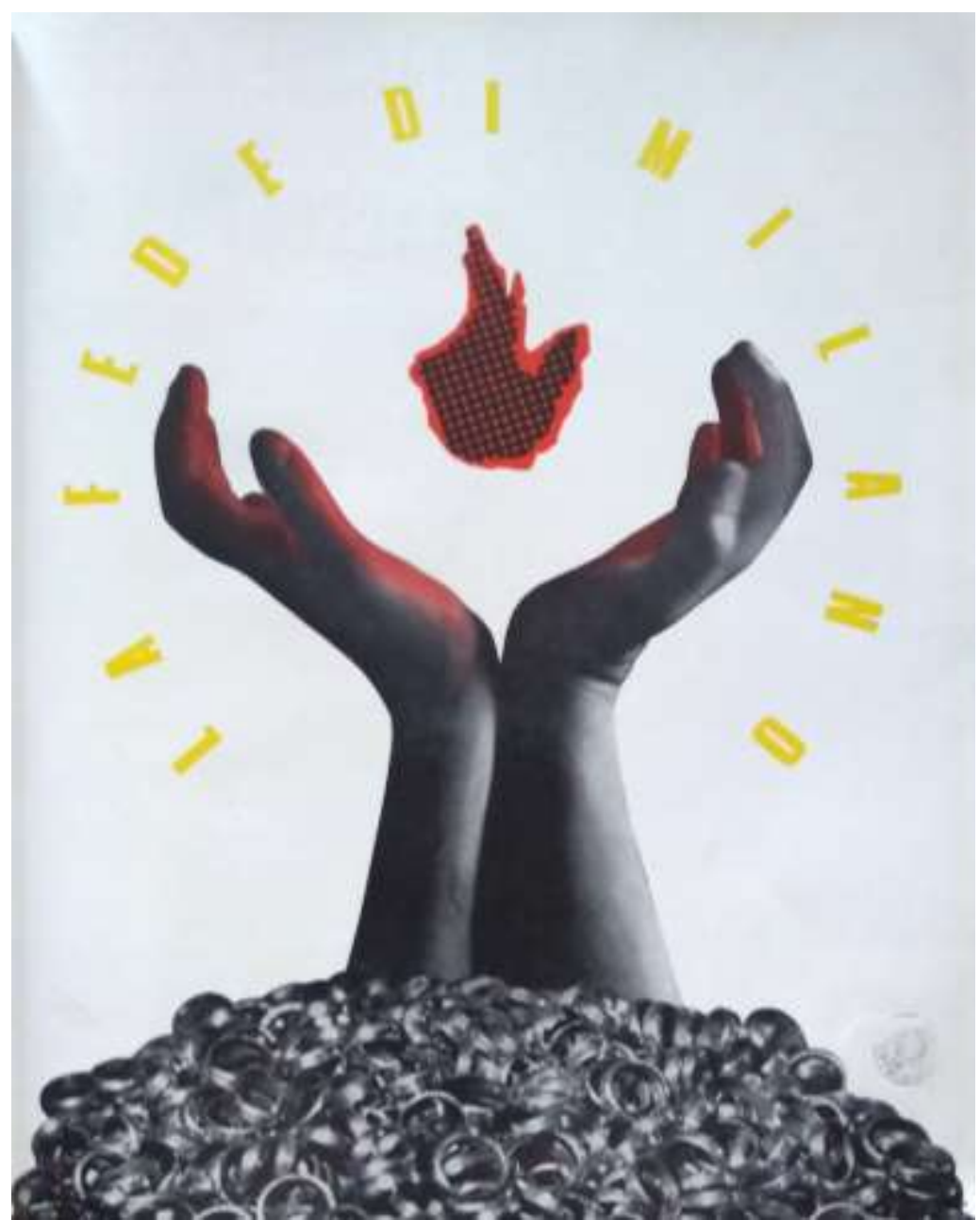

Figure 15. Example of Layout from the Photobook Il Fascio Primogenito, Curated by the Milanese Fascist Party, Officine Grafiche Esperia, Milano, 1938, Private Collection

\section{Conclusion}

The study of Fascist photobooks revealed the role played by avant-garde languages in regime's Mythopoeia, an aspect that is often overlooked. For the historiography, in fact, the image of Fascism is that of the L.U.C.E. Institute, whose modesty is also confirmed by Gabriele D'Autilia, the main connoisseur of archival material: he admits that this type of photography "will not succeed in creating the incisive ideological alphabet of the Nazi image (real and idealized at the same time), whose own clarity is able to create a mythical suspense." ${ }^{34}$ In

34. D'Autilia, Storia della Fotografia in Italia dal 1939 a Oggi (Turin: Einaudi, 2012), 206207. 
propaganda photobooks, instead, aberrations of perspective, details and chiaroscuro effects are used to generate symbols, that is, visible and concrete objects of a reality, which is that of Fascist era. Moreover, these symbols are made up from the internalization of rules and group norms, making individual behavior correspond to the government motion.

The study also demonstrates that, within the photographic books of fascist propaganda, the relationship between text and image does not involve in a slavish dictatorship of the word on the image - as claimed by Roland Barthes, one of the first scholas to introduce a reflection on the nature of information transmitted by photography ${ }^{35}$ - but gains new connotations, characterized by a drasting reduction of writing in favour of a narrative autonomy of the iconic datum. In this way, the photographic reproduction, though enclosed by a written text, becomes the protagonist of the layout. The latter also participate to the trasmission of the information, enhancing the significance of the phototext.

The variability of the relationship between text and photography is an incisive strategy to trigger the transformation of fascist utopia into myth. As Pelayo argues, the utopia is a "rational construction", which "shows us how things are with a mathematical analysis," 36 while myth is "hope in what is to come, that is, fulfilment of the promise of history." 37 Thus, when the presumed objectivism (utopia) of the image is sublimated in strongly suggestive forms (myth), the observer's critical sense is no longer protected from all the possible artifices of the framing.

[...] what has been conceived as utopia, once it has been adopted by the masses passing from reason to emotion, can change its structure and its function untili $t$ become myth, since at the bottom of every utopia there is always a mythical idea. ${ }^{38}$

So, in this sophisticated device of persuasion, the image has above all a mythpoietic function, rather than a cultural and informative one. Modern photographic language is used to describe Mussolini's Italy, proud of its traditions and its history but also projected towards a new idea of progress: glimpses deeply rooted in common image are put near photographs in which the Italian landscape is a reclaimed nature crowded by chimneys and skyscrapers.

In this way, Roland Barthes' perspective is completely turned upside down. The French philosopher, in fact, describes photography as an "emanation of the referent:" 39 therefore, it is bound to the real object to which it refers. In regime propaganda devices, instead, the truth of photography is radically questioned: it

35. Cf. R. Barthes, "Il Messaggio Fotografico, 1961," in L'Ovvio e l'Ottuso. Saggi Critici III, 5-21 (Turin: Einaudi, 1985), 5-21.

36. M. G. Pelayo, Miti e Simboli Politici (Turin: Borla, 1970), 35.

37. Ibid.

38. Ibid, 37.

39. Barthes, La Camera Chiara. Nota sulla Fotografia (Turin: Einaudi, 2003), 81. 
offers a representation, in which the real is present only as a quotation or fragment. So, within the propaganda photobooks the photography opens up a self-referential, a hyper-real space, completely detached from the referent. Hyperreality doesn't represent anything: it presents.

\section{Bibliography}

AA.VV. Campo Grafico: 1933-1939 [Graphic Field: 1933-1939.] Milan: Electa, 1983.

AA.VV. Campo Grafico: La Sfida della Modernità [Graphic Field: The Challenge of Modernity.] Milan: Centro Studi Grafici di Milano, 2003.

Anonymous. "Il Volto della Nuova Italia" [The Face of New Italy.] Il Corriere Fotografico 30, no. 6 (1933): 31.

Anonymous. “Libri Fotografici” [Photographic Books.] Natura 8, no. 10 (1936): 27.

Anonymous. "Italia Imperiale" [Imperial Italy.] L'Uffficio Moderno 13, no. 7 (1937): 341.

Baltzer, N. Die Fotomontage im Faschistischen Italien. Aspekte der Propaganda unter Mussolini [The Photomontage in the Fascist Italy. Aspects of Propaganda under Mussolini.] Berlin: de Gruyter, 2015.

Barthes, R. “Il Messaggio Fotografico, 1961” [The Photographic Message, 1961.] In L'Ovvio el'Ottuso. Saggi Critici III, 5-21. Turin: Einaudi, 1985.

Barthes R. La Camera Chiara. Nota sulla Fotografia [Camera Lucida. Note on Photography.] Turin: Einaudi, 2003.

Bellavista, M. "Per un'Arte Fotografica al Tempo di Mussolini" [For a Photographic Art at the Time of Mussolini.] Galleria 14, no. 4 (1936): 4-7.

Boggeri, A. "La Fotografia alla Fiera di Milano" [Photography at the Milan Fair.] Natura 5, no. 3 (1932): 43-48.

Campany, D. "The Photobook: What's in a name?" The Photobook Rewiew. Aperture 7 (2014): 2-7.

Chiabrando, M. "Guido Modiano e la Nuova Tipografia Italiana" [Guido Modiano and the New Italian Typography.] In TDM5: Grafica Italiana, edited by G. Camuffo, M. Piazza and C. Vinti. Mantova: Corraini; Milan: Triennale Design Museum, 2012.

Chinellato, A. and C. G. Noventa. La Superficie Bianca. Il Prodotto Editoriale tra Storie e Progetti [The White Surface. The Editorial Product between Stories and Projects.] Padova: Libreria Universitaria, Padova, 2013.

Chiti, G. "Il Libro Fotografico in Italia dal 1940 al 1980" [The Photographic Book in Italy from 1940 to 1980.] AFT. Rivista di Storia e Fotografia 19, no. 37/38 (2003): 78-111.

Colombo, F. Libri Giornali e Riviste a Milano: Storia delle Innovazioni nell'Editoria Milanese dall'Ottocento ad Oggi [Books, Newspapers and Magazines in Milan: A History of Innovations in Milanese Publishing from the Nineteenth Century to the Present.] Milan: Abitare Segesta, 1998.

D'Autilia, G. 2005. Il Fascismo senza Passione. L'Istituto L.U.C.E. [Fascism without Passion. The L.U.C.E. Institution.] In L'Italia del XX secolo. Le Fotografie e la Storia, edited by G. De Luna, G. D'Autilia and L. Criscenti, 91-116. Turin: Einaudi, 2005.

D'Autilia, G. Storia della Fotografia in Italia dal 1939 a Oggi [The History of Photography in Italy from 1939 to Date.] Turin: Einaudi, 2012. 
D'Autilia, G. L.U.C.E. The Italian Collective Consciousness. Rome: Rai Edu and L.U.C.E. Institution, 2014.

Dradi, C. Millenovecentotrentatre: Nasce a Milano la Grafica Moderna [One Thousand Nine Hundred Thirty-Three: Modern Graphics is Born in Milan.] Milan: Ufficio Stampa del Comune di Milano, 1973.

Gomez Palacio, B. and A. Vit. Graphic Design Referenced: A Visual Guide to the Language, Applications and History of Graphic Design. Beverly: Rockport, 2010.

Isnenghi, M. "Iconografia della Stampa Fascista" [Fascist Press Iconography.] Belfagor: Rassegna di Varia Umanità 32, no. 3 (1977): 344-352.

L.U.C.E. L'Italia Fascista in Cammino [Fascist Italy on its Way.] Rome: Istituto Poligrafico dello Stato, 1932.

Mannucci, S. La Fotografia dell'Istituto L.U.C.E. Storia e Critica [L.U.C.E. Insitution Photography. History and Critique.] s.n., s.l., 2014.

Massani, G. La Sua Terra [His Land.] Bergamo: Istituto Italiano d'Arti Grafiche, 1936.

Meggs, P. B. A History of Graphic Design. New York: J. Wiley \& Sons, 1998.

Milanese Fascist Party (curated by). Il Fascio Primogenito. Milan: Officine Grafiche Esperia, 1938.

Modiano, G. “Fotografia 1931" [Photography 1931.] L'Industria della Stampa 3, no. 6 (1931): 101-102.

Modiano, G. “Fotografia 1931" [Photography 1931.] Campo Grafico 2, no. 12 (1934): 274-275.

Morgagni, M. (Ed.) Imperial Italy XIV E. F. Milan: La Rivista Illustrata del Popolo d'Italia, 1937.

Müller, J. and J. Wiedemann. Graphic Design: 1890-1959. Volume 1. Köhln: Taschen, 2019.

Mussolini, B. Vita di Arnaldo [Life of Arnaldo.] Milan: Popolo d'Italia, 1932.

Ottaviani, G. Le Veline del Minculpop: Aspetti della Propaganda Fascista [The Govern Statements: Aspects of Fascist Propaganda.] Milan: Todariana, 1999.

Paoli, S. 1999. "L'Annuario di Domus del 1943" [The 1943 Domus Yearbook.] In A Paolo Costantini. Fotografo e Collezionista (Dedicated to Paolo Costantini, Photographer and Collector), edited by T. Serena, 99-128. Pisa: Scuola Normale Superiore, Pisa, 1999.

Parr, M. and G. Badger. The Photobook: A History. Volume I. London: Phaidon, 2004.

Patti, G., L. Sacconi and G. Ziliani. Fotomontaggio: Storia, Tecnica, Estetica [Photomontage: History, Technique, Aesthetics.] Milan: Mazzotta, 1979.

Pelayo, M. G. Miti e Simboli Politici [Political Myths and Symbols.] Turin: Borla, 1970.

Pellegrini G. "La Fotografia e il Libro Moderno" [Photography and the Modern Book.] Galleria 15, no. 1 (1936): 3.

Pellittieri, G. and O. Rossi. "Campo Grafico" [Graphic Field.] Homo Faber 20 (1953): 1-8.

Piazza, C. Pho-to-Booked. Un Libro con le Foto di 107 Libri con le Foto [Pho-to-Booked. A Book with the Photos of 107 Books with the Photos.] Rimini: Digitalprint, 2016.

Ponti, G. "Discorso Sull'arte Fotografica” [Discourse on Photographic Art.] Domus 5, no. 53 (1932): 285-288.

Rich. "Bibliografia Fotografica” [Photo Bibliography.] Il Corriere Fotografico 36, no. 2 (1939): 41-43.

Rich. "Finalmente un Libro" [Finally a Book.] Il Corriere Fotografico 36, no. 4 (1939): 98.

Rossi, A. "Scopi Semplici" [Simple Pourposes.] Campo Grafico 1, 1 (1933): 3.

Russo, A. Fascismo in Mostra [Fascism on Show.] Rome: Editori Riuniti, 1999.

Starace, A. “Editorial.” Gioventù Fascista 3, no. 3 (1933): 1. 
Tranfaglia, N. La Stampa del Regime, 1932-1943. Le Veline del Minculpop per Orientare l'Informazione [The Regime's Press, 1932-1943. The Government Statements to Guide the Information.] Milan: Bompiani, 2005.

Vinti, C. "Modiano e la 'Mostra Grafica' alla VII Triennale" [Modiano and the Graphic Exhibition at the VII Triennale.] Progetto Grafico 4-5 (2006): 50-63.

Von Graefe, A. Il Nuovo Volto d'Italia [The New Face of Italy.] Milan: Mondadori, 1933. 
